\title{
ESTUDO BIOSSISTEMÁTICO DE DIFERENTES TAXONS DO GÊNERO Otylosanthes Sw. (LEGUMINOSAE - PAPILIONOIDEAE)
}

\author{
ALICE BATTISTIN \\ Naturalista
}

Orientador: Prof. Dr. PAULO SODERO MARTINS

Dissertação apresentada à Escola Superior de Agricultura "Luiz de Queiroz", da Universidade de São Paulo, para obtenção do Título de Mestre em Genética e Melhoramento de Plantas.

$P|R A C| C A B A$

Estado de São Paulo - Brasil

Julho, 1981 
Ao meu pai,

irmãos

$\dot{e}$

amigos,

DEDICO 


\section{AGRADECIMENTOS}

A autora expressa os sinceros agradecimentos a todas as pessoas

e instituições que, direta ou indiretamente, colaboraram para

a realização do presente trabalho, e especialmente:

- ao Prof. Dr. Paulo Sodero Martins, pela orientação e ami $z$ ade ;

- aos Profs. Dr. Natal Antônio Velzo, Ricardo Bohrer Sgrizlo e Isaias olivio Geraldi pela oportuna orientação na parte estatistica do trabalho;

- ao Centro de Energia Nuclear na Agricultura (CENA/USP), na pessoa do Prof. Dr. Akihiko Ando, pela disponibilidade e empréstimo do material;

- ao Corpo Docente do Departamento de Genética, pela dedicação e ensinamentos;

- ao Programa Interinstitucional de Capacitąão de Docentes da CAPES e ao Conselho Nacional de Desenvolvimento Cientifico e Tecnológico ( $C N P q)$, pelo apoio financeiro recebido durante o curso;

- aos colegas do curso que compartilharam de todos os momentos vividos durante o decorrer do mesmo, em especial ao Eng? Agr? Mauro Nóbrega da Costa, à Eng? Agro Maria Lidia Paterniani e ao Eng? Florestal Antônio Rezende Soares, pela amizade e aju 
da na coleta de dados;

- aos funcionários do Departamento de Genética da Escola Supe rior de Agricultura "Luiz de Queiroz" da Universidade de São Paulo, pelá maneira atenciosa de atendimento;

- à Escola Superior de Agronomia de Paraguagu Paulista, na pessoa do seu Diretor, Prof. Aracynio Tortolero Araújo, pelo auxilio financeiro dado para a montagem da Dissertação;

- à Srta. Dra. Rachel Elisabeth Domarco, pela disponibilidade e ajuda na construção dos gráficos;

- à Sra. Diva Athiée, secretária do Convênio CENA/IAEA/PNUD, pe la versão do Summary;

- ao Sr. João Eduardo Pizotto, da Seção de Física de Solos do CENA/USP, pelos serviços de datilografia e montagem das tabelas. 


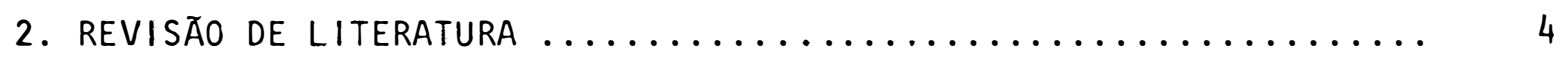

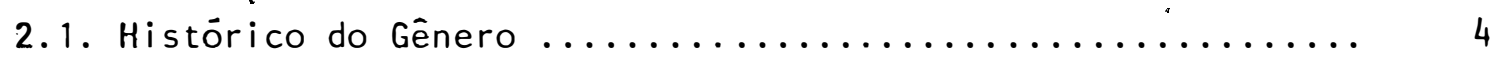

2.2. Comentärios Sobre os Caracteres Morfolögicos .......... 7

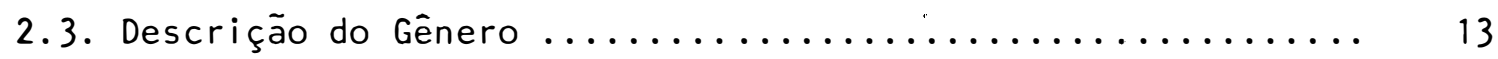

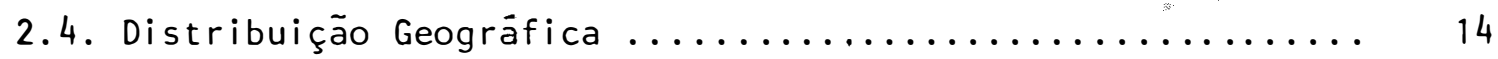

2.5. Descrição das Espēcies Analisadas no Presente Trabalho .... 15

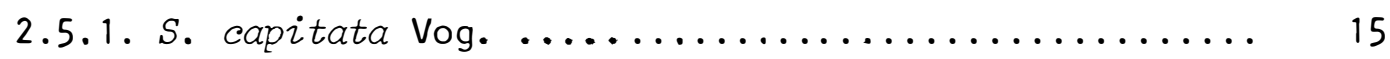

2.5.2. S. macrocephala M.B. Ferr. et Sousa Costa ......... 18

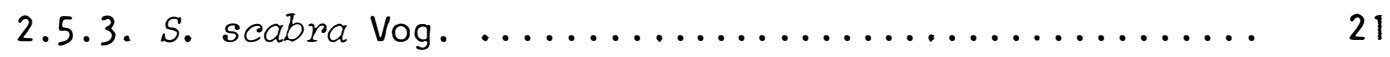

2.5.4. S. grandifolia M.B. Ferr. et Sousa Costa ......... 25

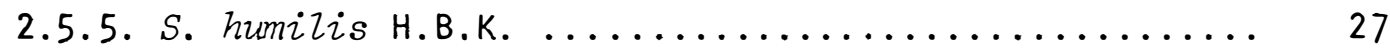

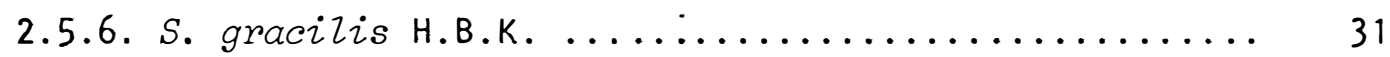

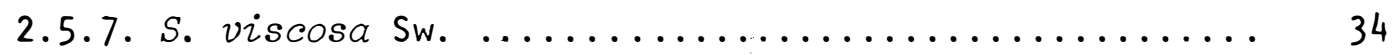

2.5.8. S. guianensis (Aubl.) Sw. var. microcephala M.B. Ferr. et Sousa Costa .................... 36

2.5.9. S. guianensis (Aubl.) Sw. var. canescens M. B. Ferr.

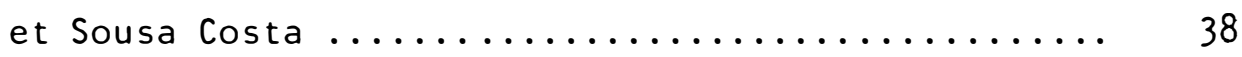

2.5.10.S. guianensis (Aubl.) Sw. var. vulgaris M.B. Ferr.

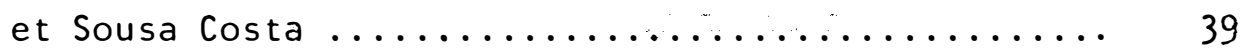

2.6. Biologia da Semente ....................... 41

2.6.1. Caracteristicas Morfolögicas ............... 41

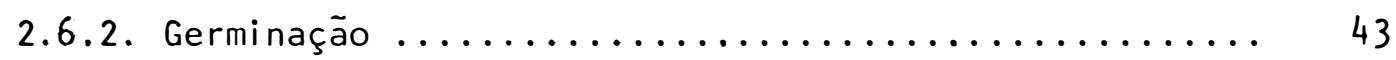

2.7. Nümero de Cromossomos .................... 45

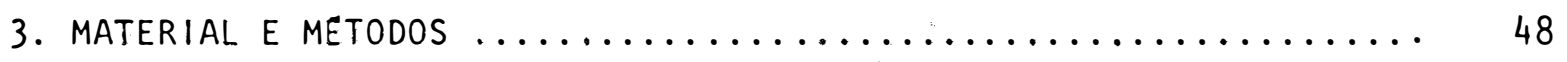

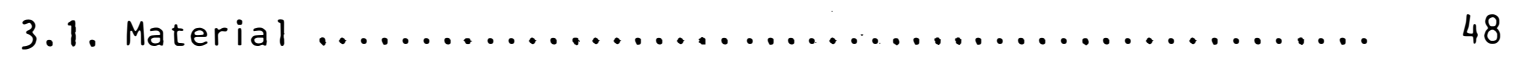


Pägina

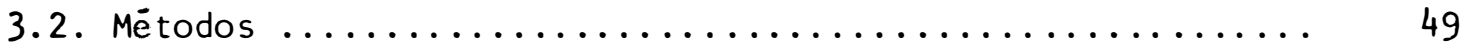

3.2.1. Preparo das Sementes e Semeadura .............. 50

3.2.2. Instalação do Experimento ................. 50

3.2.3. Anālise Taxonômica .................... 51

3.2.4. Porcentagem de Germinação das Sementes ......... 52

3.2.5. Mitoses em Pontas de Raizes ............... 53

3.2.6. Anālise Para Avaliar as Características Morfológicas Vegetativas, Florais e do Fruto ............ 54

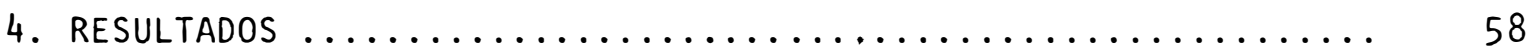

4.1. Anālise da Variância das Mensurações dos Caracteres ..... 58

4.2. Biologia da Semente ....................... 62

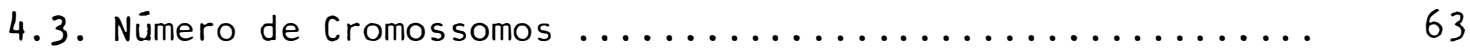

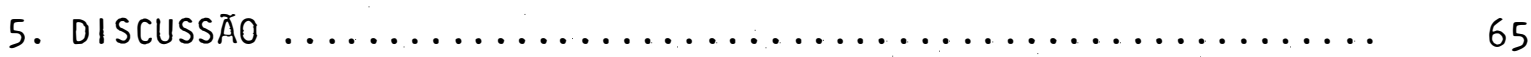

5.1. Anālise da Variância das Mensurações dos Caracteres ..... 65

5.2. Biologia da Semente ........................ 73

5.3. Nümero de Cromossomos $\ldots \ldots \ldots \ldots \ldots \ldots \ldots \ldots \ldots \ldots \ldots \ldots$

6. CONCLUSOES $\ldots \ldots \ldots \ldots \ldots \ldots \ldots \ldots \ldots \ldots \ldots \ldots \ldots \ldots \ldots \ldots \ldots \ldots$

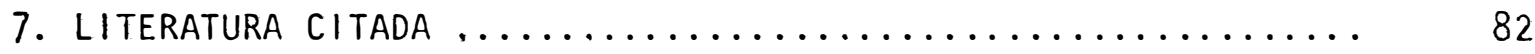

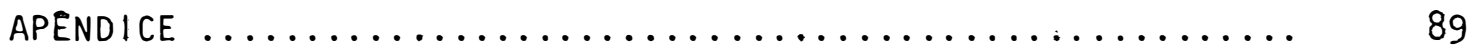




\section{LISTA DE TABELAS}

Tabela

Pāgina

1 - Análise da variância individual e anälise da variância conjunta de alguns caracteres vegetativos das espëcies: $S$. capitata $\left(E_{1}\right), S . m a$ crocephala $\left(\mathrm{E}_{2}\right)$, S. scabra $\left(\mathrm{E}_{3}\right)$, S. grandifolia $\left(\mathrm{E}_{4}\right)$, S. humilis $\left(\mathrm{E}_{5}\right)$, S. gracilis $\left(\mathrm{E}_{6}\right)$, S. viscosa $\left(\mathrm{E}_{7}\right)$ e $S$. guianensis .......

2. Análise da variância individual e anālise da variância conjunta de alguns caracteres florais de $S$. capitata $\left(E_{1}\right)$, S. macrocephala $\left(E_{2}\right)$, S. scabra $\left(\mathrm{E}_{3}\right)$, S. grandifolia $\left(\mathrm{E}_{4}\right)$, S. humilis $\left(\mathrm{E}_{5}\right)$, S. gracilis $\left(\mathrm{E}_{6}\right)$, s. viscosa $\left(\mathrm{E}_{7}\right) \mathrm{e}$

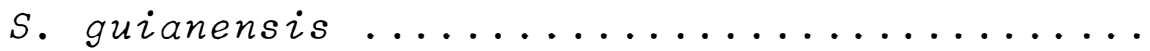

3 - Análise da variância individual e análise da variância conjunta de alguns caracteres do frü to das espécies: $S$. capitata $\left(E_{1}\right), S$. macrocephala $\left(\mathrm{E}_{2}\right)$, S. scabra $\left(\mathrm{E}_{3}\right)$, S. grandifolia $\left(\mathrm{E}_{4}\right)$, S. humilis $\left(\mathrm{E}_{5}\right)$ S. gracilis $\left(\mathrm{E}_{6}\right)$, S.

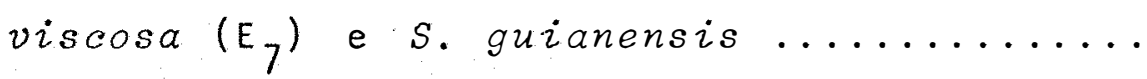

4 - Anālise da variância conjunta de alguns carac teres vegetativos de 3 variedades de $S$. guianensis: S. guianensis var.microcephala, $S$. 
guianensis var. canescens e S. guianensis var.

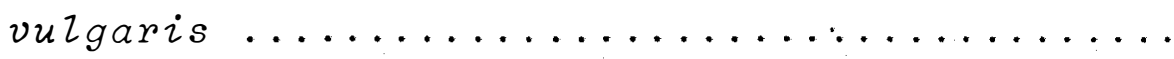

5 - Anālise da variância conjunta de alguns caracteres florais de 3 variedades de $S$. guianensis: S. guianensis var. microcephala, S. guianensis var. canescens e $S$. guianensis var.

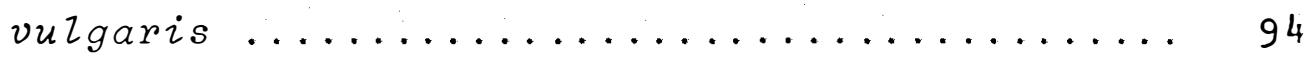

6 - Anālise da variância conjunta de alguns caracteres do fruto de 3 variedades de $S$. guianensis: S. guianensis var. microcephala, S. guianensis var. canescens e S. guianensis var.

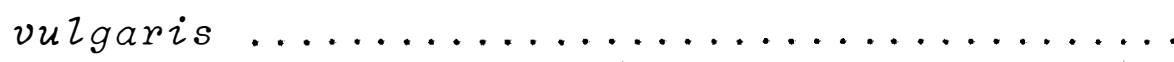

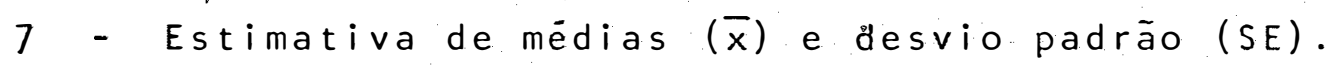

8 - Porcentagem de dormencia das sementes de 7 espécies e. 3 variedades de Stylosanthes Sw., em 3 ensaios de germinação, durante 15 dias .....

9 - Número de cromossomos obtidos pela contagem de metāfases mitóticas ao microscópio, de células de ponta de raiz de 7 espécies e 3 variedades

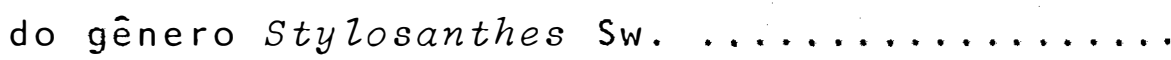




\section{LISTA DE FIGURAS}

Figura

Pägina

1 Distribuição de caracteres vegetativos: comprimento do folílo central (A), largura do falíolo central (B), comprimento do folíolo lateral direito (C), largura do folíolo lateral direito (D), comprimento da estipula (E), largura da estipula (F), comprimento do dente (G) e comprimento do internōdio (H), das espee cies $S$. capitata Vog., S. macrocephala M. B. Ferr. et Sousa Costa e S. scabra Vog. Estação Experimental de Anhembi, ESALQ/USP, Piracicaba, SP, $1981 \ldots \ldots \ldots \ldots \ldots \ldots \ldots \ldots \ldots \ldots \ldots \ldots \ldots \ldots \ldots \ldots$

2: - Distribuição de caracteres florais e do fruto: comprimento do estandarte (1), largura do estandarte (J), comprimento da asa (K), largura da asa $(L)$, comprimento do pedünculo $(M)$, com primento do cälice (N), comprimento do artícu lo superior do fruto (0), largura do artículo superior do fruto (P), comprimento do articulo inferior do fruto (Q), largura do artículo inferior do fruto (R), comprimento do apêndice terminal (S) e peso de 100 sementes (T), das espēcies $S$. capitata Vog., S.macrocephala M.B. Ferr. et Sousa Costa e S. scabra Vog. Es 
tação Experimental de Anhembi, ESALQ/USP, Piracicaba, SP, $1981 \ldots \ldots \ldots \ldots \ldots \ldots$

3 - Distribuição de caracteres vegetativos: comprimento do foliolo central (A), largura do folíolocentral (B), comprimento do folíolo lateral direito (C), largura do folíolo lateral direito (D), comprimento da estipula (E), largura da estípula (F), comprimento do dente (G) e comprimento do internódio (H), das espé cies S. grandifolia M.B. Ferr. et Sousa Costa, S. humilis H.B.K., S. gracilis H.B.K. e S. viscosa Sw. Estação Experimental de Anhembi, ESALQ/USP, Piracicaba, SP, $1981 \ldots \ldots \ldots \ldots$

4 - Distribuição de caracteres florais e do fruto: comprimento do estandarte (1), largura do estandarte ( $J)$, comprimento da asa (K), largü ra da asa (L), comprimento do pedúnculo (M), comprimento do cálice (N), comprimento do articulo superior do fruto (0), larqura do art $\underline{\mathbf{I}}$ culo superior do fruto (P.), comprimento do a $\underline{r}$ ticulo inferior do fruto (Q), largura do artí culo inferior do fruto (R), comprimento do apêndice terminal ( $S$ ) e peso de 100 sementes 
Figura

(T), das espēcies S. grandifolia M.B. Ferr. et Sousa Costa, S. humilis H.B.K.,. S. gracilis H.B.K. e S. viscosa Sw. Estação Experimental de Anhembi, ESALQ/USP, Piracicaba, SP,

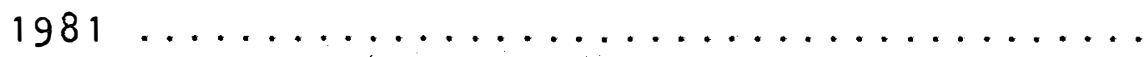

5 - Distribuição dos caracteres vegetativos: comprimento do folíolo central (A), largura do fo liolo central (B), comprimento do folíolo late ral direito (C), largura do folíolo lateral di reito (D), comprimento da estípula (E), largura da estipula (F), comprimento do dente (G) e comprimento do internódio $(H)$, das variedades vulgaris M.B. Ferr. et Sousa Costa, microcepha La M.B. Ferr. et Sousa Costa e canescens M.B. Ferr. et Sousa Costa. Estação Experimental de Anhembi, ESALQ/USP, Piracicaba, SP, $1981 \ldots$.

6 - Distribuição de caracteres florais e do fruto: comprimento do estandarte (1), largura do estandarte (J), comprimento da asa (K), largura da asa $(L)$, comprimento do pedúnculo (M), comprimento do cälice (N), comprimento do artículo superior do fruto (0), largura do artículo superior do fruto (P), comprimento do artículo 
inferior do fruto (Q), largura do artículo inferior do fruto $(R)$, comprimento do apêndice terminal (.S) e peso de 100 sementes, das varie dades vulgaris M.B. Ferr. et Sousa Costa, microcephala M.B. Ferr. et Sousa Costa e canescens M.B. Ferr. et Sousa Costa. Estação Experimental de Anhembi, ESALQ/USP, Piracicaba,

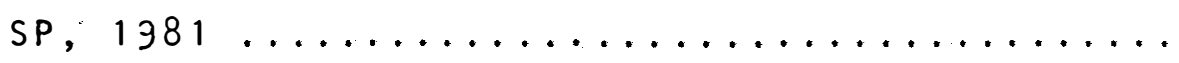

7 - Representação grä́fica da porcentagem de sementes germinadas, por dia, em 7 espécies e 3 variedades de Stylosanthes Sw., em temperatura constante de $15^{\circ} \mathrm{C}$. IGEN-ESALQ/USP. 1980....

8 - Representação grä́fica da porcentagem de sementes germinadas, por dia, em 7 espécies e 3 variedades de Stylosanthes Sw., em temperatura constante de $25^{\circ} \mathrm{C}$. IGEN-ESALQ/USP. 1980. ...

9 - Representação gräfica da porcentagem de semen tes germinadas, por dia, em 7 espécies e 3 variedades de Stylosanthes Sw., em temperatura constante de $35^{\circ} \mathrm{C}$. IGEN-ESALQ/USP. 1980. .... 


\section{ESTUDO BIOSSISTEMATICO DE DIFERENTES TAXONS DO GENERO}

Styrosanthes SW. (LEGUMINOSAE - PAPILIONOIDEAE)

$\begin{aligned} & \text { Alice Battistin } \\ & - \text { Naturalista - }\end{aligned}$

Prof. Dr. Paulo Sodero Martins

- orientador -

\section{RESUMO}

Neste trabalho, foi realizado um estudo biossistemático de 7 espécies e 3 variedades do gênero Stylosanthes Sw., com a finalidade de se obter informações básicas so bre a variabilidade intra e interespecífica de diferentes caracteres morfológicos.

o material estudado é proveniente de diferentes estados: S. capitata Vog. e S. scabra Vog. säo procedentes do estado do Rio de Janeiro; S. humilis H.B.K.,procedente do estado de Goiás; S. macrocephala M.B. Ferr. et Sousa Costa, S. grandifolia M.B. Ferr. et Sousa Costa, S. gracizis H.B.K., S. viscosa Sw. e as 3 variedades de $S$. guianensis (Aubl) Sw. (microcephala M.B. Ferr. et Sousa Costa, canescens M.B. Ferr. 
e.t Sousa Costa e vulgaris M.B. Ferr. et Sousa Costa), procedentes do estado de Minas Gerais.

o trabalho foi dividido em. trés etapas. A prí meira, conduzida na Estação Experimental do Anhembi, pertencente ao Departamento de Genética da ESALQ/USP, situada no Mu nicípio de Piracicaba, SP, teve como objetivo estimar o grau de variabilidade dentro de cada espécie e variedade e o grau de diversificação existente entre as espécies e variedades, pela análise estatística de 19 caracteres morfológicos considerados importantes do ponto de vista taxonómico. A segunda etapa, realizada em laboratório, constou do estudo da biologia da semente, sendo determinada a porcentagem de dorméncia e germinação sob temperaturas constantes de $15^{\circ} \mathrm{C}, 25^{\circ} \mathrm{C}$ e $35^{\circ} \mathrm{C}$ para cada espécie e variedade. A terceira etapa, também desenvol vida em laboratório, visou determinar o nümero de cromossomos das espécies e variedades ainda não estudadas citologicamente, pela contagem em mitoses de pontas de raiz.

Os resultados obtidos neste trabalho permitiram concluir que: a) existe uma grande variabilidade genética dentro de cada espécie e variedade e entre as espécies e variedades para todos os caracteres mensuráveis vegetativos, flo rais e do fruto, indicando considerável capacidade de adaptação a diferentes ambientes, podendo ser espécies indicadas pạ ra pastágens em diferentes situações climáticas, solos e alti tudes; b) a análise dos caracteres permitiram uma distinção 
mais nítida das espécies, bem como maior conhecimento do rrau de estabilidade de cada uma e a relação filogenética existente entre elas, possibilitando estabelecer com mais clareza as linhas evólutivas do gênero; c) as variedades microcephala, ca nescens e vulgaris apresentam grau de variabilidade tão amplo quanto aquele observado dentro e entre as diferentes espécies, consequentemente, não permitindo estabelecer um critério diferencial entre espécies e variedades; d) o dimorfismo exibido pelo lomento com 1 ou 2 artículos, encontrados nas diferentes espécies e variedades, sugere que, além de ser um caráter adaptativo, os grupos taxonómicos semelhantes estão filoge neticamente relacionados; el o forte grau de dorméncia eviden ciado nas sementes das 7 espécies $\varepsilon 3$ variedades caracterizam as sementes do tipo duras, bem como constituem um mecanismo de sobrevivéncia altamente vantajoso, pelo fato de manté-las no solo durante o período ém que as condições ambientais são desfavoráveis à germinação e desenvolvimento da plântula; f) as 7 espécies e 3 variedades do gènero Styzosanthes Sw., quanto ao número de cromossomos, são poliplóides do número básico $x=$ 10. sendo S. capitata Vog. e S. scabra Vog. tetraplóides, com $2 n=40$, e as demais espécies e variedades, diplóides, com $2 n=20$. 


\title{
BIOSYSTEMATIC STUDY OF DIFFERENT TAXA OF THE GENERA
}

Stylosanthes SW. (LEGUMINOSAE-PAPILIONOIDEAE)

Alice Battistin

- Naturalista -

Prof. Dr. Paulo Sodero Martins

- Adviser -

\section{SUMMARY}

\begin{abstract}
A biosystematic study of 7 species and 3 varieties of Stylosanthes was carried out to obtain basic information on the intra and interspecific variability of the different morphological characters.
\end{abstract}

The material used came from different states of Brasil: S. capitata Vog. and $S$. scabra Vog. from Rio de Janeiro; S. humilis H.B.K. from Goiàs; S. macrocephala M.B. Ferr. et Sousa Costa; S. grandifolia M.B. Ferr. et Sousa Costa; $S$. gracilis H.B.K., S. viscosa Sw. and the three S. guianensis (AubI.) Sw. variieties (microcephala M.B. Ferr. et Sousa Costa, canescens M.B. Ferr. et Sousa Costa and v:Igaris M.B. Ferr. et Sousa Costa) from Minas Gerais. 
first one was carried out at the Experiment station of the Department of Genetics of ESALQ/USP, at Anhembi, Piracicaba, S.P. With the objective of estimating the degree of variability within species and varieties, through statistical analysis of 19 morphological characters, considered tanoxomically important. The second phase, carried out in the laboratory, consisted of a biological study of the seed, with determination of the percentage of dormancy and germination under constant temperatures (15, 25 and $35^{\circ} \mathrm{C}$ ) for each species and variety. In the third phase, also carried out in the laboratory, the number of chromosomes was determined for species and varieties not yet cytogenetically studied, by counting mitosis of root tips.

The results obtained lead to the conclusion that, (a) there is large genetic variability within each species and variety and within species and varieties for measurable vegetative, flower and fruit characters, indicating a considerable capacity of adaptation to different environments; these species can be used in pastures at different climatic, soil and altitude situations; (b) analysis of characters showed a high degree of variation among the species, as well as improved knowledge of the degree of stability of each and the phylogenetic relationship existing among them, making it possible to establish the evolutionary lines of the genera more clearly; (c) the varieties microcephala, canescens and vulgaris, showed degree of variability as large as observed within and between species, therefore the data do not permit the establishment of any 
differential criterium between species and varieties; (d) the polymorphism shwon by lomentum with 1 or 2 articulations found in different species and varieties, suggests that besides the adaptation character, taxonomically similar groups are phylogenetically related; (e) the high degree of dormancy shown by seeds of the 7 species and 3 varieties are characteristic of hard seeds, as well as representing a highly'advantageous survival mechanism as they are kept in the soil during the period when the environmental conditions do not favour germination and seedling development; ( $f$ ) with regard to number of chromosomes, the 7 species and 3 varieties of the gen Stylosanthes are polyploids, with basic number $x=10, S$. capitata Vog. and $S$. scabra Vog. are tetraploids, with $2 \pi=40$, and the other species and varieties are diploids, with " $n=20$. 


\section{INTRODUÇAO}

A família Leguminosae é uma das mais numerosas do reino vegetal, possuindo cerca de 600 gèneros e 17.600 espé cies, aproximadamente. Ocorre nos ambientes mais variados, em diferentes altitudes e latitudes (HUTCHINSON, 1964), desta cando-se pelo elevado número de espécies úteis ao homem. BEN THAM (1859) relacionou 52 gèneros desta família que ocorrem no Brasil. Alguns destes gêrieros são mais estudados, em vir tude de sua maior importáncia económica, alimentar,medicinal, forrageira, etc. Dentre esses gèneros, Stylosanthes sw. foi incluído por BOGDAN (1977) entre os de maior importáncia para a formação de pastagens, em regiões tropicais, destacando-se as espécies $S$. fruticosa (Retz.) Mohlenbrock, S. guianensis (Aubl.) Sw., S. hamata (L.) Taub. e S. humilis H.B.K. O género é formado de espécies que possuem grande variabilidade natural, sendo esta característica muito importante em progra mas de melhoramento. Além disso, constitui uma fonte econômica de produção de proteínas para alimentação animal, pelo 
alto potencial forrageiro, considerado um fator primordial da indústria pecuária e contribui para suprimento de nitrogénio ao solo, através da fixação simbiótica do elemento presente na atmosfera.

- uso de leguminosas em pastagens brasileiras ainda se encontra em estágio precário, embora sua utilização seja justificada pela baixa qualidade das pastagens naturais que apresentam capacidade de suporte extremamente reduzida. O emprego destas leguminosas num programa de melhoramento, visando a obtenção de cultivares adaptados às condições de pasto reio, depende da existéncia de informações básicas relativas ao modo de reprodução, taxonomia, resisténcia a pragas e doenças, etc.

Visando, portanto, a obtenção de informações básicas de natureza biossistemática em diferentes espécies do gênero Stylosanthes Sw., o presente trabalho tem os seguintes objetivos:

a) Estimar a variabilidade entre e dentro dos diferentes taxons, através da análise estatística, utilizando dados obtidos por mensurações de caracteres vegetativos, florais e do fruto;

\footnotetext{
b) Analisar as características morfológicas, grau de dorméncia e germinação das sementes dos diferentes taxons;
} 
c) observar citologicamente mitoses, para con. tagem e determinação do número de cromossomos de cada espécie e variedade. 


\section{REVISAO DE LITERATURA}

\subsection{Histörico do Gēnero}

o gênero stylosanthes sw., pertence à tribo Hedysareae, família Leguminosae e sub-família Papilionoideae. De acordo com MOHLENBROCK (1958), o nome genérico Stylosanthes foi mencionado pela primeira vez por 0. SWARTz em 1788 (Prod. Veg. Ind. Occ. 108), com a descrição de duas espécies: S. procumbens ( = hamata (L.) Taub.), e S. viscosa Sw. Posteriormente, WILLDENOW (1800), na 4a. edição de "Species Plantarum", fez constar 5 espécies e DON (1832) elevou o número de espëcies para 13. A primeira revisão do gẽnero foi feita por VoGEL (1838), citado em t'MANNETJE (1977), que reconhecia 15 espécies, divididas em duas secções: Eustylosanthes e Styposanthes, baseado na auséncia ou presença de um eixo rudimentar a sociado a cada flor. TAUBERT (1891), citado por t'MANNETJE (1977), relatou 22 espécies pertencentes ao gênero Stylosanthes sw. baseando seus trabalhos em caracteres morfológicos, relações genéticas e distribuição geográfica. 
No Brasil, BENTHAN (1859), tratando do gènero em questão, reconheceu na secção Styposanthes 4 espécies: $S$. bracteata Vog., S. capitata Vog., S. ruelzioides Mart. 8 S. scabra Vog. e, na secção EustyZosanthes, G espécies: S. viscosa Sw., S. guianensis Sw., S. montevidensis Vog., S. Zeiocarpa Vog., S. humizis H.B.K. e S. angustifolia Vog. MOHLENBROCK (1958), em sua revisão do gênero Stylosanthes Sw., relacionou um total de 25 espécies. Nesta ocasião, mudou a nomenclatura da secção Styposanthes Vog. (in Linnaea 12:68. 1838), para secção I, Stylosanthes, baseado na mesma característica propos ta por VOGEL (1838), isto é, presença de um eixo rudimentar as sociado a cada flor e a presença de 2 brácteolas internas; e a secção Eustylosanthes Vog. (in Linnaea 12: 63. 1838), para cec ção II, Astyposanthes (Herter.) Mohlenbrock, stat. nov. na ausência do eixo rudimentar, associado a cada flor, e a existência de uma bracteola interna. Na secção Stylosanthes I, rela cionou as seguintes espécies: $S$. capitata Vog., S. bracteata Vog., S. calcicola Small, Man., S. mexicana Taub., s. erecta Beauv., S. scabra Vog., S. tuberculata Blake, S. sympodialis Taub., S. fruticosa (Retz.) Monlenbrock, S. subsericea Blake, S. macrocarpa Blake, S. Nervosa Maebr., S. hamata (L.) Taub., S. sericeiceps Blake. Destas espécies, citou para o Brasil: S. capitata Vog., S. bracteata Vog., S. scabra Vog. Na secção Astyposanthes, rilatou as seguintes espécies: S. biflora (L.) BSP.. S. guianensis (AubI.) Sw., S. angustifolia Vog., S. Zeio carpa Vog., Cayennensis Mohlenbrock, S. hippocampoides Mohlen 
brock, S. macrosoma Blake, S. viscosa Sw., S. figueroae Mohlen brock, S. montevidensis Vog., S. humizis H.B.K. Entre estas espécies, citou para o Brasil: S. guianensis (Aubl.) Sw., S. angustifolia Vog., S. Zeiocarpa Vog., S. viscosa Sw., S. monte vidensis Vog. e S. humizis H.B.K. Nesta mesma revisão, MOHLENBRoCk, colocou S. rigida spreng, S. tenuiflora G. Don, $S$. suborbiculata Chiov. e S. rupestris stuck, como espécies duvidosas, por apresentarem similaridades muito acentuadas com outras espécies. Mais tarde, MOHLENBROCK (1963), reconsiderou S. suborbiculata chiov. como espécie e incluiumais 4 espécies no gênero: S. ingrata Mohlembrock, S. mucronata Mohlembrock, S. suffruticosa Mohlembrock e S. sundaica Mohlembrock. Desta for ma, o nümero de espécies foi elevacio para 30.

t'MANNETJE (1977) reconheceu 6 variedades de $S$. guianensis: guianensis, gracilis (Kunth) Vog., intermedia(Vog.) Hassler, robusta, variedade nova, dissiflora (Robins. Seat) e Zongiseta (Mich) Hassler, baseado’ na distribuição geográfica e nos caracteres morfológicos: forma e tamanho da folha e nervação e tamanho da vagem.

FERREIRA e SOUSA COSTA (1979), conduzindo um ex tensivo programa de coleta de leguminosas forrageiras no estado de Minas Gerais, realizaram uma ampla revisão do gênero. Co mo resultado de suas pesquisas, restabeleceram as espécies: $S$. ruelzioides Benth., S. gracilis H.B.K., S. Zongiseta Micheli, S. hispida Rich, espécies estas colocadas por MOHLENBROCK (1958) 
como sinonímia de $S$. guianensis (Aubl.) Sw., e S. gracilis H. B.K. e S. Zongiseta (Mich.) Hassler, consideradas variedades de S. guianensis, por t'MANNETJE (1977). Além disso, descreveram 9 novas espécies: $S$. acuminata M.B. Ferr. et S. Costa, S. macrocephala M.B. Ferr. et S. Costa, S. pilosa M.B. Ferr.et S. Costa, S. aurea M.B. Ferr et S. Costa, S. campestris M.B. Ferr. et S. Costa, S. grandifolia M.B. Ferr. et S. Costa, S. Zinearifolia M.B. Ferr. et S. Costa, S. Zinearifolia M.B. Fer. et S. Costa, S. tomentosa M.B. Ferr. et S. Costa e S. debilis M.B. Ferr. et S. Costa, baseados em caracteres morfológicos florais e vegetativos. Incluíram as 9 espécies nas duas secções propostas por MOHLENBROCK (1958). Identificaram 3 varie dades de S. guianensis: S. guianensis var. vulgaris, S. guianensis var. canescens e S. guianensis var. microcephala. Des ta maneira, o número de espécies aumentou para 39, sendo que 25 ocorrem no Brasil.

\subsection{Comentārios Sobre os Caracteres Morfolōgicos}

\footnotetext{
A família Leguminosae é constituída por um grupo de plantas que apresenta uma série de caracteres típicos, que a diferencia dos demais grupos de plantas: o fruto do tipo legume, os nódulos das raízes, onde vivem simbioticamente as bactérias fixadoras do nitrogênio, o.. ovário unicarpelar, as flores tetracíclicas, etc.
} 
A taxonomia do gênero Stylosanthes Sw. tem sido baseada em várias características, que foram bem discutidas por vários autores. Entre elas, destacam-se: estames monadelfos; frutos do tipo lomento, aéreos, pequenos com um ou dois artícu los ovalados; folhas compostas por 3 foliolos; estilo glabro; semente pequena com tegumento coriáceo (BURKART, 1952).

o porte das plantas deste gênero varia de herbá ceo a subarbustivo: ereto, semiprostrado e prostrado. Podem ser plantas anuais, como é o caso de S. humilis H.B.K., e plan tas perenes, como S. guianensis (Aubl.) Sw. 0 tipo perene, segundo SANTHIRASEgARAM (1975), desenvolve um diàmetro de apro ximadamente $15 \mathrm{~cm}$ acima da superfície do solo, depois de ter sido submetido a pastagens frequentes, o qual indica carência de estado latente e resisténcia ao pastoreio. Algumas espécies possuem raízes pouco ramificadas, enquanto outras possuem raizes bastante ramificadas. Em ambos os tipos, encontram-se, na maioria das espécies, os nódulos bacterianos.

Quanto ao caule, algumas espécies, principalmen te as de porte ereto e semiprostrado, mostram ser bastante lenhosas na base e herbáceas no ápice.

As estípulas são bidentadas, possuindo pilosidą de variada ou glabra. De acordo com MOHLENBRock (1958), apre sentam uma variação de 3 a 11 nervuras, e os dentes, em geral, são menores que a lámina da estípula. Em algumas espécies, a estípula apresenta estrias coloridas marrom-avermelhadoe verde. 
As folhas são alternadas, compostas por trés fọ líolos, sendo o folíolo terminal um pouco mais desenvolvido que os dois laterais, segundo BENTHAN (1859), MOHLENBROCK (1958) e FERREIRA e SOUSA COSTA (1979). Os folílos possuem formas va riadas: eliptica, lanceolada, oblonga, ovada e obovada, conforme a espécie, guardando, porém, sempre o mesmo padrão de forma dentro da mesma espécie.

A nervação pode ser do tipo camptódromá, broquí dódroma ou mista, sendo o número de nervuras variável, e alg mas espécies apresentam nervura marginal, como é o caso de $S$. gracilis H.B.K., S. campestris M.B. Ferr. et S. Costa, S. acuminata M.B.Ferr. et S. Costa e S. Zinearifolia M.B. Ferr. et S. Costa, de acordo com fERREIRA e SOUSA COSTA (1979).

o tipo básico de inflorescéncia é uma espiga, correndo variações quanto à forma, tamanho e quantidade de fla res. No Brasil, FERREIRA e SOUSA COSTA (1979) constataram as seguintes variações quanto à inflorescência: alongada e estre ta, ocorrendo em $S$. viscosa sw., S. debilis M.B. Ferr. et S. Costa, S. angustifolia Vog., S. ruellioides Benth; forma curta e mais ou menos ovóide, ocorrendo em $S$. bracteata نòg., S. macrocephala M.B. Ferr. et.S. Costa, S. Zinearifolia M.B. Ferr. et S. Costa; forma eliptica oblonga, em S. pizosa M.B. Ferr.et S. Costa; forma semi-globóide e congesta em S. campestris M.B. Ferr. et S. Costa, S. acuminata M.B. Ferr. et S. Costa, S. gran difolia M.B. Ferr. et S. Costa e S. gracilis H.B.K. As flo- 
res sao protegidas por brácteas e bracteolas. As brácteas são similares às estípulas, com ápice bidentado e bainha foliácea. Na maioria das espécies, as brácteas são mais longas que largas, porém, em algumas espécies são mais largas que longas, co mo acontece em $S$. macrocephala M.B. Ferr. et S. Costa, S. brac teata Vog., S. capitata Vog. e S. angustifolia Vog. (MOHLENBROCK, 1958) e S. macrocephala M.B. Ferr. et S. Costa, S. Zine arifolia M.B. Ferr. et S. Costa (FERREIRA e SOUSA COSTA, 1979).

Em algumas espécies do gênero ocorre um eixo ru dimentar denso-ciliado: é uma característica que tem grande va lor na divisão taxonómica, pois serviu de base para os autores dividirem o gēnero em 2 secções: secção Stylosanthes, quando o eixo está presente, e secção Styposanthes, na auséncia do eixo.

A cor das flores pode ser amarela ou laranja, com estrias purpúreas. Existem algumas espécies que apresentam flores brancas, como acontece em $S$. acuminata M.B. Ferr.et S. Costa, e em algumas variedades de S. guianensis (Aubl.) Sw. O cálice apresenta um tubo bastante alongado e estreito, expan dindo na parte apical 4 a 5 lobos, medindo de 4 a $15 \mathrm{~mm}$ de com primento (MOHLENBROCK, 1958) e 5 a $12 \mathrm{~mm}$ de comprimento para LEITÃo filHo e LOVAOINI (1974). A corola é do tipo papilionóide composta de um estandarte, 2 asas e 1 quilha. 0 androceu é formado por 10 estames monadelfos, unidos em um tubo, sendo 5 estames de anteras maiores e filetes curtos, e 5 estames de anteras menores e filetes mais. longos. O gineceu pos- 
sui ovārio súpero monocarpelar com 1 ou 2 óvulos, com estilnalongado e glabro, dotado de estigma terminal.

o fruto é uma vagem do tipo lomento com 1 ou 2 artículos férteis, com apéndice terminal persistente no ápice, variando de tamanho, sendo bastante longo no $S$. humilis H.B.K., S. Zeiocarpa Vog., S. bracteata Vog. e S. Zinearifolia M.B. Ferr et Sousa Costa, medianamente longo em $S$. scabra Vog., S. debilis M.B. Ferr. et S. Costa, S. macrocephala M.B. Ferr. ot. S. Costa e S. capitata Vog., e reduzido nas demais espécies (FERREIRA E SOUSA COSTA, 1979).

As sementes são pequenas, duras, de coloração variada: pretas, amarelas, pintalgadas de escuro, marron, marmaneadas e castanho-claro, ocorrendo em algumas espécies vários tipos das cores citadas, dentro da mesma espécie.

Para LEITÃO FILHO e LOVAOINI (1974),

BARROS (1978) e BARRIGA (1979), as espécies deste gênergo apresentam um acentuado polimorfismo em diversos caracteres, como: porte da planta, presença ou auséncia de pilosidade no caule, forma e dimensões dos folíolos, número de flores por inflorescéncia, etc., sendo grande a variedade entre as espécies e dentro das espécies, devido a fatores genéticos e adaptação ao meio. Es te fato sugere que trabalhos de seleção e melhoramento poderão dar resultados satisfatórios. MOHLENBROCK (1958) reconhece S. guianensis (Aubl.) Sw. como espécie mais variável do gênero e que, devido a isto, existe uma grande confusão de nomes con- 
feridos à espécie, e TULEY (1968) e BARRos (1978) confirmaram a observação de Mohlenbrock quando verificaram que em uma popuㅡ lação de $S$. guianensis (Taub.) Sw., não selecionada, encontrase grande variação de formas, citando: hábito de crescimento variando de totalmente ereto até prostrado; caracteres como pi losidade, diámetro dos ramos, cor da semente, período de tempo para o florescimento associado ao fotoperíodo, cor da semente, forma, tamanho e cor das folhas, produção de matéria seca, dis tribuição dos ramos. Acrescentam que estes caracteres conferem à espécie um alto grau de adaptação a diferentes ambientes e, consequentemente, promissoras para formaça de pastagens. Diversos trabalhos sobre características morfo lógicas em S. humilis H.B.K. foram realizadas por CAMERON $(1967$ a,b,c,d) e BARRIGA (1979), onde constataram que o tempo de florescimento, hábito de crescimento e coloração das sementes são caracteres que apresentam o mais alto grau de variabilidade da espécie.

Como se nota, do ponto de vista forrageiro, o gênero Stylosanthes $\mathrm{sw}$. apresenta grande potencial a ser explo rado e melhorado, permitindo sua melhor utilização como forrageira. 


\subsection{Descrição do Gēnero}

Stylosanthes Sw. Prod. Veg. Ind. Occ. 108.1788 ( T: S. hamata (L.) BSP.).

Secção I. Stylosanthes

Secção Stylosanthes Vog. in Linnaea 12: 68. 1838. (T: S. hama ta (L.) Taub.).

Seç̧ão II. Astyposanthes (Herter) Mohlenbrock, stat. nov. Secção Eustylosanthes Vog. in Linnaea 12: 63. 1838. Astyposanthes Harter, in Rev. Sudamer Bot. 7: 209. 1943.

Plantas herbáceas e subarbustivas; caules, em geral, denso-ramificados, lenhosos na base e herbáceos no ápice; raízes pouco ou muito ramificadas com nódulos bacterianos; folhas compostas trifoliadas, imparipenadas; estípulas amplexi caules, bidentadas, pilosas ou glabras; presença ou auséncia de um eixo rudimentar ciliado; inflorescència tipo espiga com número de flores variando de 1 a 40, de coloração amarela, laran ja com ou sem estrias, purpúreas, envolvidas por brácteas e bracteolas; o cálice é um tubo alongado e estreito, apresentan do na parte apical 5 lobos agudos; corola do tipo papilionóide com um estandarte, 2 asas e 1 quilha encurvada menor que as asas; androceu formado por 10 estames monadelfos unidos em um tubo com 5 estamas de anteras maiores e filetes curtos e 5 estames com anteras menores e filetes longos; o gineceu é de ová rio monocarpelar com 1 ou 2 óvulos, com estilo alongadoe gla bro com estigma terminal; fruto do tipo lomento com 1 ou 2 ar- 
tículos férteis; semente ovóide, lisa, de cor preta, marron, a marela, pintalgada de escuro, marmoreada e castanho-claro.

\subsection{Distribuição Geográfica}

De acordo. com MOHLENBROCK (1958), o gênero StyZosanthes Sw. é nativo das savanas e äreas similares dos Estados Unidos, América Central, Antilhas, América do Sul até o norte da Argentina, Ilhas Galápagos, Africa Central, Madagascar, Sul da India e Ceilão. Algumas espécies foram introduzi das na Malásia e na Austrália. Ocorre também no México, Guatemala, Panamá, Colómbia e Venezuela.

Após um considerável tempo de estudos sobre o gênero, FERREIRA e SOUSA COSTA (1979) constataram no Brasil a existéncia de 25 espécies e 3 variedades, demonstrando, desta maneira, que o nosso país possui mais da metade das espécies ocorrentes no mundo. A ocorréncia deste gênero vai desde o norte até o sul do país. Das 25 espécies mencionadas para o Brasil, 19 são encontradas no Estado de Minas Gerais, indicando, provavelmente, que este estado é um dos centros de diversi ficação do gènero no Brasil.

A maioria das espécies deste gênero ocorre em solos pobres, de baixa fertilidade, com elevado teor de alumínio, muito pobres em cálcio e fósforo, o que confere às espé cies especial interesse para futuros trabalhos de melhoramento. 
Outras espécies, como S. gracilis H.B.K., S. viscosa Sw. e $S$. guianensis (Aubl.) Sw., ocorrem com frequència em restinga,bem como em altitudes de 1200 a 1300 m, mostrando serem espécies de grande amplitude ecológica, podendo ser indicadas para pastagens em diferentes situações de clima, solo e altitudes.

\subsection{Descrição das Espécies Analisadas no Presente Trabalho}

Secção I. StyZosanthes

\subsubsection{S. capitata Vog.}

in Linnaea 12: 70. 1838, ex charm.

Subarbusto de ereto a prostrado, ramoso, sublenhoso, às vezes mostrando córtex suberoso ria base dos caules; ramos cobertos de pélos claros, densos e curtos, apresentando raras ou muitas cerdas, sendo a pilosidade mais densa nos nós; folhas com foliolos de oblongos a elipticos, às vezes obovados, alcançando 30 a $40 \mathrm{~mm}$ de comprimento, por 12 a $15 \mathrm{~mm}$ de largura, de ápice agudo ou mucronado, densamente piloso em ambas as faces; com 8 a 12 pares de nervuras conspícuas e com pe cíolo de 2 a $6 \mathrm{~mm}$ de comprimento, densamente piloso com eixc de comprimento variável alcançando $3,5 \mathrm{~mm}$ de comprimento; estí pulas mais longas que largas, com 16 a $20 \mathrm{~mm}$ de comprimentopor 6 a $8 \mathrm{~mm}$ de largura; os dentes em geral possuem $1 / 3$ do compri mento total, são agudos, enquanto que a bainha é pilosa-cerdosa, com 2 a 3 pares de nervuras; a inflorescencia é formada 
de espigas elípticas, mais longas que largas, de ovóides a oblongas, multifloradas, com 20 a $40 \mathrm{~mm}$ de comprimento por 1,5 a 2,5 mm de largura; as brácteas sao oblongas, com 9 a $13 \mathrm{~mm}$ de comprimento da ponta dos dentes até a base e 6 a 9 mm de larg ra; os dentes são curtos e largos, pilosos, com pelos claros; bainha com 3 a 4 pares de nervuras conspícuas e um reduzido fo líolo central, frequentemente de cor avermelhada; 2 bracteolas ciliadas, com 2 a $3 \mathrm{~mm}$ de comprimento; presença de um eixo ru dimentar densamente ciliado, alcançando o comprimento do lomen to; as flores são de cor amarela; cálice com 4 a 5 mm de comprimento, com 4 lobos ciliados; estandarte de orbicular a obo vado com 4 a $6 \mathrm{~mm}$ de comprimento, sem estrias, asa e carena ob longas, com 4 a $5 \mathrm{~mm}$ de comprimento, auriculadas na base; lomento com 3 a $3,5 \mathrm{~mm}$ de comprimento por 2 a $2,5 \mathrm{~mm}$ de largura, reticulado, com 2 artículos férteis, o inferior às vezes abortado, o superior glabro e o inferior levemente pubescente; apêndice terminal uncinado com cerca de 1 mm de comprimento, às vezes com ralos pélos; sementes variando de cor quase preta a amarela, por vezes mosqueada, com $2 \mathrm{~mm}$ de comprimento.

\section{Considerações Gerais Sobre a Espécie}

A espécie $S$. capitata Vog. mostra ser muito pro missora como forrageira, por apresentar uma série de características agronômicas importantes, tais como: ótima toleráncia a patógenos, forte resistència a antracnoses, boa adaptação aos solos de baixa fertilidade e toleráncia a níveis tóxicos 
de alumínio: Entretanto, a espécie mostra pouca tolerància aos solos com pH alto e um alto nível de cálcio. FERREIRA e SOUSA COSTA (1979) acrescentam que em solos pobres e em condições naturais, no Brasil, esta espécie é atacada por antracnoses e por pragas na espiga, especialmente depois dos frutos for mados, verificando-se a destruição das sementes. Acrescentam também que os caules são prostrados, longos, pouco numerosos, atingindo mais de um metro, com elevada produção de sementes. MOHLENBROCK (1958) E FERREIRA E SOUSA COSTA (1979) menCIOMIM que quase sempre o lomento é formado por 2 artículos férteis e normalmen te o sistema radicular apresenta raízes longas não muito divididas, tanto na superfície como em profundidade.

Atualmente, existem cerca de 57 ecotipos no ba co de germoplasma do CIAT. Os ecotipos diferem morfologicamente e foi encontrada uma considerável variação com relação à época da floração.

Em alguns ecotipos já foram contados o número de cromossomos, sendo que alguns possuem $2 n=20$, enquanto outros são tetraplóides, com $2 n=40$.

\section{Distribuição Geogrāfica}

Segundo MOHLENBRock (1958), esta espécie é conhecida na Venezuela e, no Brasil, foi encontrada nos estados de Maranhão, Piauí e Minas Gerais. FERREIRA e Sousa costa (1979) acrescentam para o Brasil a ocorréncia nos estados de 
Goiás, Bahia, Pará, Ceará, Pernambuco, Páraíba, Paraná e Distrito Federal.

2.5.2. S. macrocephala M.B. Ferr. et Sousa Costa sp.n. in Anais Soc. Bot. Bras. XXVIII Cong. 77: 102. 1977

E um subarbusto ramoso, com 20 a $60 \mathrm{~cm}$ de altura; o caule é piloso, com cerdas esparsas e pêlos claros; a estipula é obovada e pilosa, com uma bainha que atinge mais ou menos 9 a $10 \mathrm{~mm}$ de comprimento por 5 a $6 \mathrm{~mm}$ de largura, dotada de 11 a 13 nervuras; possui dentes estreitos com 5 a 6 mm de comprimento; a folha é formada de 3 folíolos pubescentes a glabros com 20 a $55 \mathrm{~mm}$ de comprimento e 10 a $19 \mathrm{~mm}$ de largura, possuindo de 7 a 9 pares de nervuras; o pecíloló bastante pi loso e atinge um comprimento de 1 a $2 \mathrm{~mm}$; a inflorescência é formada de espigas ovóides, com poucas flores dispostas em capítulos densos, atingindo de 22 a $24 \mathrm{~mm}$ de comprimento por 22 a $26 \mathrm{~mm}$ de largura; as flores são amarelas; cálice tubuloso, com 5 a 7 mm de comprimento e 4 lobos ciliados; estandarte obovóide ou às vezes oblongo com 4 a 5 mm de comprimento, de cor amarelo claro e sem estrias; asa e carena oblongas, com 5 mm de comprimento; brácteas imbricadas, largas, elípticas de ápice bífido e extremidades unifoliadas, pubescentes a cerdosas, com 12 a $14 \mathrm{~mm}$ de comprimento por 8 a $9 \mathrm{~mm}$ de largura, ge ralmente dotadas de 11 a 13 nervuras; bracteolas são hialinas e subpaleáceas, oblongas de ápice ciliado; presença de um 
eixo rudimentar na base das flores; o fruto é um lomento suborbiculado, com 2 artículos férteis, reticulado, glabro, às vezes apresenta-se com glàndulas sésseis no ápice, sendo que o artículo superior é glabro com 3 a 4 mm de comprimento e 2,5 a $3 \mathrm{~mm}$ de largura e o inferior é menor e piloso; o apéndice terminal é muito curto, recurvado e mucronado; as sementes são pretas, raramente amarelas, com 2 a $3 \mathrm{~mm}$ de comprimento e 2,2 a 2,5 mm de largura.

\section{Considerações Gerais Sobre a Espēcie}

Esta espécie foi classificada por Ferreira e Sousa Costa, que a incluíram na secção I Stylosanthes Vog., pelo fato de possuir um eixo rudimentar na base das flores. 0 nome macrocephala foi dado devido ao tamanho de sua inflorescência. No campo, distingue-se das demais espécies por apre sentar suas flores bem maiores. É uma espécie que apresenta várias características semelhantes a $S$. capitata Vog., S. brac teata Vog. e S. Zinearifolia M.B. Ferr. et S. Costa, porém pos sui características próprias que a distingue das demais espécies. Distingue-se do $S$. capitata Vog. por apresentar porte mais baixo, inflorescência curta e ovóide, brácteas maiores, dentes estreitos e compridos e sementes mosqueadas amareladas. Distingue-se do $S$. bracteata Vog. por apresentar o lomento com 2 artículos férteis. E facilmente distinguível do $S$. Zinearifolia M:B. Ferr. et S. Costa, pelo formato de nervuras dos seus folílos e pela ausência de xilopódio. 
- Dutra característica importante da espécie é a permanéncia fechada das brácteas depois de secas, contendo as sementes no seu interior, facilitando a colheita. Possui uma nodulação bacteriạna, bastante boa, sendo os nódulos pequenos, não atingindo mais de $2 \mathrm{~mm}$ de diámetro. Em algumas áreas naturais, a espécie é atacada moderadamente por antracnose.

\section{Distribuição Geogrāfica}

Até o presente momento, sabe-se da ocorréncia desta espécie no Brasil, talvez pelo fato de ser uma espécie recentemente classificada e estudada apenas por um grupo de pesquisadores brasileiros, interessados em espécies brasileiras. Foi constatada a existência no estado de Minais Gerais, nas proximidades de Belo Horizonte (Betim), em Lagoa Santa, na Serra do Cipó e entre Datas e Diamantina. Ocorre também na Bahia, no Distrito Federal e em Goís. Geralmente, é encontrada em relevo variado, no cerrado, campo-cerrado, campo limpo, sobre latossolo amarelo distrófico, cambissolos e areias quartzosas. Quase sempre esta espécie ocorre junto a $S$. capitata Vog., S. guianensis var. vulgaris M.B. Ferr. et S. Costa, e espécies dos gêneros Cassia, Mimosa, Aristida, Echino Zaena, etc. 
2.5.3. S. scabra Vog.

in Linnaea, 12: 69. 1838, ex char.

\section{Sinonimia}

Stylosanthes diarthra Blake, in Proc. Biol. Soc. Wash. 33:49. 1920 ( T: Jahn 169:).

Stylosanthes gloiodes Blake, loc. cit. 45.1920. ( $T$ : Townsend A. 57:)

Stylosanthes plicata Blake, loc. cit. 46. 1920. (T. Kuntzes.n.:).

\section{Subarbusto, de ereto a subereto, muito ramoso,} alcançando $1,5 \mathrm{~m}$ de altura, recoberto por pélos curtos, algumas vezes viscosos, raramente glabrascentes; folhas compostas por folíolos de elipticos a obovados, de oblongos a lanceolados, obtusos a mucronados no ápice, com pélos curtos e densos nas faces,algumas vezes glabrescentes, com cerdas raras, com 4 a 6 pares de nervuras conspícuas, com um comprimento variando de 15 a $20 \mathrm{~mm}$ de comprimento por 5 a $8 \mathrm{~mm}$ de largura; o pecío lo é canaliculado, com pêlos densos, mede de 2,5 a $6 \mathrm{~mm}$ de com primento; estipulas obovadas piloso-cerdosas, com 20 a 25 mm de comprimento (inclusive dentes); os dentes atingem cerca de 1/3 do comprimento da estípula; a inflorescência é formada por espigas mais longas que largas na maioria dos exemplares, são estreitas, multifloradas, atingindo de 10 a $30 \mathrm{~mm}$ de comprimento por 8 a $10 \mathrm{~mm}$ de largura; brácteas elípticas, unifo- 
liadas, piloso-cerdosas, com 7 a 8 mm de comprimento (incluindo dentes); dentes triangulares com cerca de $1 / 3$ do comprimen to total; bracteolas 1 ciliada; presença do eixo rudimentar; flores amarelas com estrias purpúreas; cálice com 6 a $7 \mathrm{~mm}$ de comprimento, 4 lobos glabros; estandarte obovado, estriado, estrias mais pronunciadas na face inferior, atingem de 5 a 6 mm de comprimento; asa estreita falcada com $3,4 \mathrm{~mm}$ de comprimento e carena falcada com 4 a $5 \mathrm{~mm}$ de comprimento, alargada e auriculada; fruto do tipo lomento com 2 articulações férteis, - artículo superior glabro e glabrescente e às vezes reticulado enquanto que o inferior é piloso; semente com $2 \mathrm{~mm}$ de comprimento, de coloração variando de preta, marron-escuro, marron claro e amarelo.

\section{Considerações Gerais Sobre a Espécie}

Esta espécie foi descrita por MOHLENBROCK (1958) e por FERREIRA e SOUSA COSTA (1979). Os dois autores concordam com a mesma descrição de características, apenas variando nas medidas de alguns caracteres, como: comprimento, largura e tamanho, confirmando que a espécie possui grande variabilidade em seus caracteres. LEITÁ filHo e LOVADINI (1974), trabaIhando com várias espécies de Stylosanthes Sw. mencionam $S$. scabra Vog., como uma espécie de fácil germinação embora a variação seja menor do que outras espécies para alguns caracteres como acontece com a consistência do caule que sempre se apresenta lenhoso. FERREIRA e SOUSA COSTA (1979) observaram 
que no estado de Minas Gerais apresenta hábito vegetativo muito diversificado, desde ereto a prostrado, concordando com LEI TAO FILHO e LOVADINI (1974) de que o caule é sempre de consistência lenhosa na base. A espécie é encontrada em todos os tipos de solos e formações vegetativas. A floração varia de precoce a tardia. Os dois artículos férteis são sempre encon trados, e ocorre uma elevada produção de sementes. Paraferreira e Sousa Costa a cor da semente é sempre amarela, porém, em experimentos fora do estado de Minas Gerais a espécie apresenta várias cores: preta, marron-escuro, marron-claro e amare 1a. Apresenta também uma grande variação na pilosidade dos caules e folhas. A nodulação bacteriana não é muito abundante. Quanto a antracnose, mostra muita variação: em algumas localidades são bastante atacadas, enquanto que em outras mostram-se um pouco tolerantes.

\section{Distribuição Geogrāfica}

A espécie mostra-se largamente dispersa. MOHLENBRock (1958) menciona a ocorrència na Bolívia, Colómbia, Equador e Venezuela e, no Brasil, nos estados da Bahia, Mato Grosso, Minas Gerais, Paraíba, Pernambuco, São Paulo e Rio Gran de do Sul. FERREIRA e SOUSA COSTA (1979) acrescentam os esta dos de Goiás, Distrito Federal, Rio de Janeiro, Ceará,Rio Gran de do Norte, Pará e Roraima. 
Seção II. Astyposanthes (Herter) Mohlenbrock, stat. nov.

2.5.4. S. grandifolia M.B. Ferr. et S. Costa sp. n. in Anais Soc. Bot. Bras. XXVIII Cong. 77:102. 1977.

\section{Sinonimia}

Stylosanthes guianensis (Aubl.) Sw. var.robusta Mohlenbrock, var. nov. Aust. J. Bot. 25, 347-62. 1977.

Subarbusto ereto, algumas vezes prostrado, com 1 a 2 m de altura, pouco ramificado, com ramos virgados pilosos a glabros; é uma espécie perene; possui as estípulas obo vadas às vezes quadrangulares, pilosas, com cerdas amarelas, atingindo um comprimento de 18 a $25 \mathrm{~mm}$ de comprimentc por 8 a 10 mm de largura; em geral são dotadas de 5 a 7 nervuras; o pecíolo é piloso, com 8 a $10 \mathrm{~mm}$ de comprimento; os folíolos pubescentes a glabros com 20 a $55 \mathrm{~mm}$ de comprimento por 8 a 18 mm de largura, dotados de 11 a 12 pares de nervuras ténues na inserção com a nervura média e proeminentes nas extremidades; a inflorescéncia é formada de espigas oblongas, ovóides, çom poucas flores em forma de capitulo denso, com 14 a $24 \mathrm{~mm}$ de com primento e 20 a 25 mm de largura; brácteas imbricadas, lạgas, elípticas, de ápice bífido, sendo as externas unifoliadas, pubescentes, cerdosas com 12 a. $14 \mathrm{~mm}$ de comprimento por 8 a $9 \mathrm{~mm}$ 
de largura, com 11 a 13 nervuras; auséncia de eixo rudimentar plumoso na base das flores; bracteolas 2 , hialinas e subpaleá ceas, oblongas de ápice ciliado; as flores são de cor amarela; o cálice é tubuloso exserto, com 5 a 7 mm de comprimento, com 4 lobos, ciliados; o estandarte é obovóide ou oblongo, com 4 a 5 mm de comprimento; asa e carena oblongas com $5 \mathrm{~mm}$ de comprimento; o fruto é um Iomento suborbiculado, reticulado, glabro, às vezes com glàndulas sésseis no ápice, com 3 a 4 $\mathrm{mm}$ de comprimento e 2,5 a $3 \mathrm{~mm}$ de largura; 0 apéndice terminal é curtíssimo, recurvo e mucronado; as sementes são pretas e briIhantes, raramente amarelas, com $2,2 \mathrm{~mm}$ a $3 \mathrm{~mm}$ de comprimento por 1,8 a $2,2 \mathrm{~mm}$ de largura.

\section{Considerações Gerais Sobre a Espécie}

Esta espécie, inicialmente, foi descrita por MOHLENBROCK (1958), como uma variedade de S. guianensisvar. ro busta, pelo fato de apresentar diferenças morfológicas bastante acentuadas em alguns caracteres como folíolos grandes e lan ceolados, caule robusto, nervuras conspícuas e reticulares, ti po de vagem, inflorescéncia maior de $20 \mathrm{~cm}$ e diferente hábito de crescimento quando comparada a outras variedades. FERREIRA e SOUSA COSTA (1979) classificaram a variedade robusta como uma espécie distinta, do gènero Stylosanthes sw. 0 nome da es pécie foi dado em função do grande desenvolvimento dos seus fo lílos. A partir daquela data, a variedade robusta passou a chamar-se S. grandifolia M.B. Ferr. et S. Costa. Esta espé- 
cie distingue-se das demais, por apresentar, além das características descritas por MOHLENBROCK (1958), comprimento e largü ra das estípulas e brácteas bem maiores que as demais espécies, bem como o formato e o número de nervuras. Assemelha-se ao $S$. biflora (L.) BSP., S. guianensis (Aubl.) Sw.. S. campestris M. B. Ferr. et S. Costa, S. gracizis H.B.K., S. aurea M.B. Ferr. et S. Costa e S. acuminata M.B. Ferr. et S. Costa, pelo tipo do fruto. A espécie apresenta uma grande variabilidade. Encontram-se plantas com hábito vegetativo ereto, de folílos grandes, de cor verde pouco intensa; outras plantas apresentam hábito vegetativo prostrado e outras folílos reduzidos. As flores, em geral, são grandes, atingindo até $1 \mathrm{~cm}$ de compri mento, porím, não possuem as estrias características da maioria das espécies deste gēnero. De maneira geral, a floração é precoce e relativamente curta, embora foram encontradas vari ações nas coletas desde 90 a 150 dias para o aparecimento das primeiras flores, no primeiro ano de avaliação (FERREIRA e SOU SA COSTA, 1979). Possui uma boa nodulação bacteriana. E atacada por pragas nas espigas, mas, apesar disso, a produção de sementes é elevada.

\section{Distribuição Geogrāfica}

De acordo com MOHLENBRock (1958), esta espécie ocorre na Argentina, no Paraguai e no Brasil, especificamente nos estados da Bahia, Amazonas, Mato Grosso, Minas Gerais, São Paulo e Rio de Janeiro. Para FERREIRA e SOUSA COSTA (1979), 
no Estado de Minas Gerais estende-se desde o Triàngulo Mineiro até o sul do estado, ocorrendo na região de Jaíba e Janaúba (norte), Morada Nova e Serra do Espinhaço, aparecendo em áreas florestais e em áreas em reconstituição, cerrado e caatinga, sobre latossolo vermelho-escuro e vermelho-amarelo e sobre cambissolos em relevo ondulado.

2.5.5. S. humilis H.B.K.

Nov. Gen. et Sp. 6: 506. 1823, ex char.

\section{Sinonimia}

Stylosanthes sundaica Taub. in Verh. Bot. Brand. 32: 21. 1990 ex char.

Astyposanthes humilis (HBK.) Herter, in Rev. Sudamer. Bot. 7: 209. 1943.

A espécie possui ramos usualmente ascendentes, raramente prostrados, às vezes são sublenhosos na base, alcançando $50 \mathrm{~cm}$ de comprimento; ramoso coberto com pêlos curtos e brancos, frequentemente com curtas cerdas, raramente glabro; puㅡ bescência mais forte na região dos nós; os folíolos podem ser de lanceolados a elípticos, de ápice frequentemente mucronado a agudo, ciliado com cerdas, ou glabro, apresentando 3 a 4 pares de nervuras conspícuas, os foí́olos terminais a tingem de 15 a $20 \mathrm{~mm}$ de comprimento por 2,5 a $3,5 \mathrm{~mm}$ de largura, sendo que os laterais são um pouco menores; o pecíolo 
possui de $2: 5$ a $5 \mathrm{~mm}$ de comprimento, com pélos curtos e frequentemente com cerdas; possui raquis com 1 a 2 mm de comprimento; estípulas pilosas, com 5 a $6 \mathrm{~mm}$ de comprimento; os dentes são estreitos, cobertos por longas cerdas; as espigas são curtas, com 12 a $15 \mathrm{~mm}$ de comprimento, multifloradas; flo res pouco exsertas, brácteas elípticas, com 8 a $9 \mathrm{~mm}$ de compri mento por 7 a $10 \mathrm{~mm}$ de largura (incluindo dentes), piloso-cerdosas, com 7 a 9 nervuras; os dentes são triangulares de 3 a $4 \mathrm{~mm}$ de comprimento; bracteolas 2, ciliadas no ápice; ausência de eixo rudimentar na base das flores; as flores são de cor amarela; o cálice com 4 a $5 \mathrm{~mm}$ de comprimento com 4 lobos ciliados; $\quad$ o estandarte suborbicular estriado com 4 a $5 \mathrm{~mm}$ de comprimanto; asas obovadas; carena alongada, com 3 a $4 \mathrm{~mm}$ de comprimento; o fruto é do tipo lomento, com 1 artículo fér til, medindo de 6 a $8 \mathrm{~mm}$ de comprimento (incluindo o apéndice terminall, reticulado, glabro ou com curtos pélos claros; o apèndice terminal é fortemente uncinado ou coleado com 1,5 a $3 \mathrm{~mm}$ de comprimento, tão longo ou maior que o artículo superi or; as sementes são quase sempre pretas, com 2 a $2.5 \mathrm{~mm}$ de com primento.

\section{Considerações Gerais Sobre a Espécie}

FISHER (1969) e ROBINSON E JONES (1972), citados por EDYE e CAMERON (1975), mostraram que o. S. humilis H. K., proveniente da Austrália, caracteriza-se por possuir grande concentração de nitrogènio e fósforo nas sementes maduras, en- 
quanto que nos tecidos do caule e das folhas, estes dois produtos são extremamente reduzidos. O S. humilis H.B.K. possui um valor forrageiro comprovado. MOHLENBRock (1958), quando descreveu 25 espécies do gênero, destacou S. humizis H.B. K. e S. guianensis (Aubl.) Sw. como duas espécies largamente utilizadas como pastagens em áreas tropicais e sub - tropicais da Austrália, admitindo um excelente comportamento dessas duas espéries na formação de pastagens. BURT et alii (1971) detectaram ampla variabilidade intra-específica, principalmente para o caráter tempo de florescimento, considerando a espécie a melhor entre as linhagens introduzidas com similar tempo de florescimento. Uma característica muito im. portante ca espécie é o dimorfismo exibido pela vagem, apresentando dois tipos, apendicular e inapendicular, provo cando a ocorrência de dois pontos máximos na descarga das sementes. A vagem do tipo apendicular apresenta seu ponto máximo de descarga no mês de maio e as vagens do tipo inapendicular lançam as sementes ao solo somente no final do ciclo vital da planta (BARRIGA, 1979). As vagens apendiculares devem apresentar um importante papel na distribuição da espécie a longa distáncia, pela facilidade com que se prende ao pélo dos animais através do apéndice (BOGOAN, 1977; BARRIGA, 1979).

Informações contraditórias são encontradas na literatura quanto ao lomento. Enquanto LEITÃO FILHO e LOVAOINI (1975) mencionam que a articulação superior do fruto é 
fértil e a inferior pode ou não ser fértil, BOGDAN (1977), nor outro lado, faz referéncia de que o fruto contém uma semente na articulação basal, sendo a articulação superior vazia e representada simplesmente por um apéndice terminal. Entretanto, BARRIGA (1979) encontrou frutos bi-arti culados constituídos por uma vagem basal encaixada entre as brácteas floráis, revestidas por uma casca de coloração parda e de aspecto fibroso e uma vagem superior lo calizada mais externamente e parcialmente saliente, sendo revestida por uma casca de coloração preta de aspecto coriáceo, apresentando na extremidade um apéndice. Estas controvérsias comprovam a existência de uma grande variabilidade que existe neste caráter dentro da espécie.

Outra característica é a alta porcentagem de sẹ mentes dormentes observada logo após a colheita. CAMERON (1967a) e BARRIGA (1979) consideram as propriedades de dorméncia da semente em S. humilis H.B.K. uma característica de valor altamente adaptativo, conferindo à espécie condições de so brevivéncia diante das adversidades climáticas dos ambientes.

\section{Distribuição Geogräfica}

A espécie $S$. humizis H.B.K. ocorre desde a parte central do México até a região nordeste do Brasil, engloban do além desses dois países, a Guatemala, Panamá, Colómbia, Venezuela, Austrália, Malásia, Honduras e Cuba. 
No Brasil MOHLENBROCK (1958) relaciona a ocor. rência desta espécie no Pará, na Bahia, no Ceará, Pernambuco e Rio Grande do Norte. DUCKE (1959), em coletas realizadas na Região Amazónica, encontrou o S. humilis H.B.K., além do Pará, nos territórios de Rondônia e Amapá e no estado do Maranhão. FERREIRA e SOUSA COSTA (1979), acrescentam a ocorrência no Piauí, Rio de Janeiro, Goiás, Paraíba, Ilha de Fernando de Noronha e Minas Gerais.

2.5.6. S. gracilis H.B.K.

Nov. Gen. et Sp. 6:597 ex chart

\section{Sinonimia}

S. gracilis Kunth, Nov. Gen. Sp. Plant. 6: 507, Tab. 596 (1823).

S. guianensis (Aubl.) sw. var. gracilis (kunth) Vog. Linnaea 12:66 (1838).

S. surinamensis Miq. in Linnaea 18: 567 (1844).

S. guianensis ssp. guianensis Mohlenb. Annals Missouri Bot. Gard. 44: 225-254. 1958 .

E um subarbusto, de caule estriado, pouco ramificado, piloso-cerdoso, alcançando até $1,50 \mathrm{~m}$ de altura; as folhas são compostas por folíolos de lanceolados a elípticos, com 2,4 mm de comprimento por $3,5 \mathrm{~mm}$ de largura, pubescente a 
glabro, com 4 a 6 pares de nervuras ténues e uma distinta nervura marginal; o pecíolo é piloso, possui de 2 a 3 mm de comprimento; as estípulas são oblongo-ovadas, piloso - cerdosas, com 18 a $20 \mathrm{~mm}$ de comprimento (incluindo os dentes), com 7 a 9 nervuras; os dentes são estreitos com cerca de $1 / 3$ do comprimento total; a inflorescència é formada de espigas capitadas, terminais, congestas e multifloradas; as brácteas são elípticas, piloso-cerdosas, unifolioladas, com 7 a 9 nervuras; brac teolas 2, ciliadas no ápice; auséncia de eixo rudimentar; flo res amarelas, pouco exsertas, cálice com 5 a 6 mm de comprimen to, glabro, com 4 lobos; o estandarte é suborbicular estria do nas duas faces com 4 a 5 mm de comprimento, asas e carena falcadas-oblongas, com 4 a $5 \mathrm{~mm}$ de comprimento, auriculadas; o fruto é um lomento com 3 a $3,5 . \mathrm{mm}$ de comprimento, reticulado, de glabro a pubescente; as sementes possuem coloração variada de preta a amarela, com $2 \mathrm{~mm}$ de comprimento.

\section{Considerações Gerais Sobre a Espécie}

Esta espécie foi colocada como sinonímia de $S$. guianensis ssp. guianensis, por MOHLENBROCK (1958), em sua revisão sobre o gènero. FERREIRA e SOUSA COSTA (1979), trabaIhando com várias espécies do gênero e encontrando acentuadas características diferenciais desta espécie quando comparada com S. guianensis (Aubl.) Sw. consideraram-na como uma espécie nova, dando o nome de S. parvifolia M. B. Ferr. et S. Costa porém, quando comparada com S. gracilis H.B.K.. verifi 
cáram que se tratava da mesma espécie. Após uma série de observações e consultas em materiais de herbários, restabeleceram a espécie com o nome de S. gracilis H.B.K.

Esta espécie apresenta muita semelhança com $S$. montevidensis Vog. no que diz respeito ao hábito vegetativo e várias vezes foi confundida com esta no material herborizado. Entretanto, a dispersão geográfica é bem distinta nas duas espécies: enquanto o $S$. montevidensis Vog. ocorre de São Paulo para o sul até o Paraguai e Argentina, o $S$. gracilis H.B.K. ocorre desde o sul até o norte do pais. Dutra diferenciação é quanto ao tamanho do lomento, sendo bem maior no S. montevidensis Vog. e a semente e o apêndice terminal bem mais desenvolvidos.

S. gracilis H.B.K. possui sempre pouquíssimas folhas e baixa produção de massa verde, mesmo em pleno estado vegetativo. A nodulação geralmeñte é fraca, com nódulos pequenos. E muito atacada por antracnose e por pragas na espi ga.

\section{Distribuição Geogräfica}

S. gracizis H.B.K. é encontrada no Panamá, Venezuela, Guiana Francesa, Peru, Bolivia, Paraguai e Brasil. No Brasil é encontrada nos estados de Maranhão, Paraíba,Bahia, Goiás, Màto Grosso, Pará, Rio de Janeiro, território do Rorai- 
ma, Amapá, Rio Branco, Rio Grande do Norte, Piaui, Distrito Fe deral, Pernambuco, São Páulo e Ceará.

\author{
2.5.7. S. viscosa Sw. \\ in Prod. Veg. Ind. 0cc. 108. 1788, ex char.
}

\title{
Sinonimia
}

Hedysarum hamatum B.L. Syst. Nat. 10: 1170.

1759, ex char.

Stylosanthes glutinosa H.B.K. Nov. Gen. et Sp.

6: 507. 1823, ex char.

Stylosanthes viscosc B. acutifolia Benth. in Mart. Fl. Bras. 151: 91. 1859, ex char.

Stylosanthes viscosaf. typica Hass. in Fedde, Rep. Sp. Nov. 16: 220. 1919, ex char.

Stylosanthes prostrata M.E. Jones, in Contrib. West. Bot. 15: 135. 1929. (T. Jones 24002:)

Esta espécie é representada por subarbusto, de ereto a prostrado, caule densamente pubescente com pélos visco sos, com os entre-nós de 1 a 5 cm de comprimento; as folhas são compostas de folíolos de elípticos a obovados, com uma variação de 8 a $25 \mathrm{~mm}$ de comprimento por 3 a $5 \mathrm{~mm}$ de largura,com 2 a 5 pàres de veias; o pecíolo possui de 1 a 2 mm de comprimento; as estípulas são de forma elíptica-triangulares, híspi 
das e viscosas; a bainha é tão longa quanto os dentes, possuindo 3,5 a $5,5 \mathrm{~mm}$ de comprimento por 2 a $3 \mathrm{~mm}$ de largura, possuída de 5 a 7 nervuras; os dentes são triangulares; a inflorescéncia é formada de espigas estreitas e alongadas, muito variáveis no comprimento, alcançando até $5 \mathrm{~cm}$ de comprimento, multifloradas; as brácteas externas geralmente são trifoliadas e as internas unifoliadas muito semelhantes às estipulas, dotadas de 5 a 6 nervuras; bracteolas 1, glabras e pubescentes com 2,5 a $3 \mathrm{~mm}$ de comprimento; estandarte orbicular, estriado nas duas faces, dotado de 4 a $7 \mathrm{~mm}$ de comprimento; asas auriculadas com 4 a $5 \mathrm{~mm}$ de comprimento; presença de um esporão próximo à aurícula; carena auriculada, falcada, com 3 a 4 mm de comprimento; o lomento é formado por 2 artículos, às ve zes só o superior fértil, reticulado, nervado, às vezes com pê los curtos, possui 1,5 a $2 \mathrm{~mm}$ de largura por 2 a $3 \mathrm{~mm}$ de comprimento; o apéndice términal é curtíssimo, fortemente uncina do; semente muito pequena, de cor variada, amarela, marron e preta, com saliência acima do hilo.

\section{Considerações Gerais Sobre a Espēcie}

A espécie apresentá uma apreciável gama de variação em determinados caracteres como tonalidade das folhas que vão desde verde-claro até verde bem escuro, hábito vegetativo de prostrado a ereto, espigas variando de curtas a muito longas, a ocorréncia em tipos bem diversificados de solos e ve getação. FERREIRA e SOUSA COSTA (1979) acrescentam que a es- 
pécie é encontrada desde o nível do mar até $1300 \mathrm{~m}$ (na Serra do Cipó em Minas Gerais). As plàntulas mostram um desenvolvi mento inicial muito lento e a floração vai de média a tardia. Estas diversificações nos caracteres da espécie talvez tenham sido a causa de várias sinonímias.

\section{Distribuição Geogrāfica \\ E comprovada a existència da espécie em Cuba,} República Dominicana, Jamaica, Guatemala, Hondura, México, Nicarágua, Panamá, Bolívia, Colómbia, Paraguai, Venezuela e Brasil. No Brasil, MOHLENBROCK (1958), nos estados da Bahia, Dis trito Federal, Minas Gerais, Pernambuco, Rio de Janeiro, São Paulo e Santa Catarine; FERREIRA e SOUSA COSTA (1979) acrescen tam para os estados do Pará, Rio Grande do Norte, Alagoas, Ser gipe, Ceará, Maranhão, Roraima, Mato Grosso, Espírito Santo e Paraná.

2.5.8. S. guianensis (Aub1.) Sw. var. microcephala M. B. Ferr. et S. Costa var. nov. sp. n. 1978.

As plantas são de hábito prostrado, às vezes as cendente; os ramos são longos, pubescentes, em número bastante significativo; as folhas formadas por foliolos lanceolados, pilosos ou glabros, atingindo de 25 a $30 \mathrm{~mm}$ de comprimento por 4 a $8 \mathrm{~mm}$ de largura, dotados de 5 a 7 pares de nervuras; as estípulás e as brácteas são pilosas; as inflorescências são formadas por. espigas pequenas, com poucas flores, axilares e 
terminais; o lomento é reticulado, glabro, com 2,5 a $3 \mathrm{~mm}$ de comprimento por 1,5 a $2 \mathrm{~mm}$ de largura; as sementes têm forma oblonga e são de cor amarela.

\section{Considerações Gerais Sobre a Variedade}

FERREIRA e SOUSA COSTA (1979) classificaram estas plantas como uma variedade do S. guianensis (Aubl.) Sw.., tendo por base alguns caracteres morfológicos: espigas simples, com poucas flores, plantas de hábito prostrado e brácteas in- ternas com folílo central menor em comprimento que a bainha. Acrescentam ainda, que esta variedade apresenta floração tardia, ocorrendo aos 130-150 dias. A produção de sementes é sempre elevada. A nodulação, de modo geral, é boa. É muito sensível a antracnose, limitando",desta maneira, a produção de massa-verde. E encontrada com mais frequéncia no sul e no leste do estado de Minas Gerais, em solos mais férteis. Sabese muito pouco sobre a variedade, pelo fato de ter sido apenas examinado o material colhido no estado de Minas Gerais.

\section{Distribuição Geogrāfica}

No Brasil, conforme FERREIRA e SOUSA COSTA (1979), no Estado de Minas Gerais, ocorre na Serra da Piedade, Lagoa Santa, Itabirito, Itauna, Sete Lagoas, São Gotardo, Lavras e Ćapitólio. 
2.5.9. S. guianensis (Aubl.) Sw. var. canescens M. B. Ferr. et S. Costa var. nov. sp. n. 1978.

A especie é representada por subarbusto semiere to, com caules, estípulas e brácteas cobertas por pélos claros ou pubescentes, mas sem cerdas; as folhas são formadas por fo líolos lanceolados, de ápice agudo, com 25 a $30 \mathrm{~mm}$ de comprimento por 5 a $7 \mathrm{~mm}$ de largura, com 6 a 7 pares de nervuras; a inflorescéncia é formada de espigas achatadas, de obovadas a ligeiramente triangulares, axilares e terminais; as brácteas são unifolioladas, com 7 a 9 nervuras; o fruto é do tipo lomento reticulado glabro com 2 a $2,5 \mathrm{~mm}$ de comprimento por 1,5 a $2 \mathrm{~mm}$ de largura; as sementes, em geral, são amarelas, algumas vezes pretas.

\section{Considerações Gerais Sobre a Variedade}

\section{FERREIRA e SOUSA COSTA (1979) classificaram a}

variedade canescens, caracterizando-a e diferenciando-a das de mais espécies e variedades, principalmente por apresentar espi gas múltiplas com muitas flores, plantas de hábito semiereto e brácteas internas com folílo central do mesmo comprimento que a bainha. Além disso, esta variedade apresenta os caules qua se despidos de pélos e de modo geral bastante sensível a antracnose, provocando a queda total das folhas e às vezes a pró pria morte da planta. A produção das sementes é muito elevada e a floração no primeiro ano ocorre entre 105 e 140 dias. 
O hábito vegetativo e a cor das folhas não apresentam muita vą riação quando comparada com a variedade vulgaris, enquanto que a germinação assemelha-se à variedade vulgaris. As plantas em geral são prostradas quando jovens e suberetas quando adultas. A nodulação bacteriana é bastante escassa.

\title{
Distribuição Geogrāfica
}

FERREIRA e SOUSA COSTA (1979) relataram a existéncia desta variedade no Estado de Minas Gerais, nas seguint tes localidades: Tiros, Curvelo, Lagoa Santa, Pompéu, Buritizeiro, São Gonçalo do Abaeté, Sete Lagoas, São Gotardo, Felixlàndia, Arapuã, Coronel Pacheco, Uberaba, Lavras, Juiz de fora e Belo Horizonte.

2.5.10. S. guianensis (Aubl.) Sw. var. vuzgaris M. B. Ferr. et S. Costa var. nov. sp. n. 1978

\begin{abstract}
Planta ereta, às vezes subereta, com caules, es típulas e bräcteas cobertas com pêlos simples e dotadas de cer das; os folíolos são lanceolados, de ápice agudo, piloso-cerdoso, alcançando um comprimento de 20 a $25 \mathrm{~mm}$ por 4 a $5 \mathrm{~mm}$ de largura, com 5 a 7 pares de nervuras; as estipulas e brácteas são piloso-cerdosas, sendo as brácteas unifoliadas; a inflorescéncia é representada por espigas globóides, multifloradas, axilares e terminais; o lomento é reticulado e glabro, atingindo um comprimento de 2,5 a $3 \mathrm{~mm}$ por 1,5 a $2 \mathrm{~mm}$ de largura;
\end{abstract}


a semente tem forma oblonga, variando a cor de castanho, pre ta e amarela.

\section{Considerações Gerais Sobre a Variedade}

FERREIRA e SOUSA COSTA (1979) degcreveram a variedade vulgaris caracterizando-a por possuir caule piloso cerdoso - viscoso, cerdas com até $2 \mathrm{~mm}$ de comprimento e espigas multifloradas. Das trés variedades avaliadas por estes autores é a que mais apresenta variação no hábito vegetativo, -no tamanho, na cor das folhas, na pilosidade, etc. Quanto ao hábito vegetativo, foram encontradas plantas bem prostradascom formação de raízes nos caules, plantas eretas e plantas de fä ses intermediárias entre prostrada a ereta. São plantas que apresentam significante produção"de massa verde. São bastante resistentes à seca, crescendo bem e apresentando boa capaci dade de rebrota, quando cortadas no período seco. Mostram-se bastante resistentes a antracnose. A presença de pélos simples e glandulares parece relacionar-se com maior resisténcia ao fungo. A germinação é rápida, quando as sementes forem es carificadas, ocorre de 3 a 5 dias. Apresentam ótima nodulação bacteriana, sendo uma característica que não é encontrada nas outras duas variedades estudadas, var. canescens e var. microcephala. Esta variedade é a que aparece com maior frequência nas pastagens nativas. 


\section{Distribuição Geogrāfica}

No Brasil, no estado de Minas Gerais, FERREIRA e SOUSA COSTA (1979) constataram a ocorréncia nas seguintes lo calidades: Diamantina, João Pinheiro, Uberaba, Betim, Divinópo lis, Alpinópolis, Poços de Caldas, Itauna, Capitólio, Barroso, estrada de Paracatu, Curvelo, Serra Geral, entre Mato Verde e Rio Pardo de Minas, Viçosa, Itabirito, Belo Horizonte e Sete Lagoas.

\subsection{Biologia da Semente}

\subsubsection{Características Morfolōgicas}

A forma da semente revela, em geral, o tipo de óvulo que lhe deu origem, sendo do tipo campilótropo nas Papilionoideas. Na maioria das espécies do gênero Stylosanthes Sw. as sementes possuem uma forma alongada, são muito pequenas, alcançando o máximo de 1 a $2 \mathrm{~mm}$ de comprimento dentro de um fruto deiscente do tipo lomento, possuindo 1 ou 2 articulações, conforme a espécie. A articulação superior, na maioria dos casos, é dotada de um apéndice terminal, relativamente com prido em algumas espécies e mais reduzido em outras. o apèndice terminal é uma característica muito importante na dispersão das sementes por zoocoria, pois este se prende ao corpo do ani mal e é carrégado a longas distàncias pelo mesmo. 
De acordo com BURKART (1952), o tegumento das Papilionoideas é uma estrutura homogênea, distinguin do-se anatomicamente, na constituição, 3 camadas de células. A superfície é lisa, variando a coloração de preto, marrom-escuro, marrom-claro, amarelo, esverdeado, pintalgado, marmoneado, etc. São consideradas sementes duras pelo fato de possuí rem o tegumento bastante impermeável à água e ao ar; quando seco, porém, adquirem uma certa permeabilidade quando embebidos em água. Segundo ROLSTON (1978), a dureza da semente é definida em termos de quantidade e graus de impermeabilidade. 0 hi lo é quase sempre ventral, deixando aparecer a micrópila como uma saliéncia geralmente de cor escura. Para qualquer espécie o hilo funciona como válvula higroscópica que controla a absorção da água necessária para. a germinação (ROLSTON, 1978). o albúmen é do tipo córneo quando seco e gelatinoso quando absorve água. Facilita a saida da radicula durante a germinação e constitui ao mesmo tempo um tecido de reserva alimentar. o embrião é curvo, com dois cotilédones e a radícula reta presa na parte interna dos dois cotilédones. 0 hipocótilo é pou co notado na semente seca, mas adquire muito desenvolvimento na germinação, pelo fato de serem sementes epígeas, elevando os cotilédones acima da terra. 


\subsubsection{Germinação}

As sementes para germinarem necessitam, além das condições internas, condições externas que lhes sejam favo ráveis. Isto envolve um espaço de tempo entre a queda da semente no solo e o momento da germinação. Durante este período a semente é impedida por vários mecanismos de dorméncia.

A dorméncia é uma característica de valor altamente adaptativo, conferindo às espécies condições de sobrevi vència na forma de semente, diante da diversidade de condições ambientais. As sementes podem permanecer por longo tempo no solo e germinarem gradativamente quando as condições ambientais forem favoráveis (CAMERON, 1967a; WILLIAMS e ELLIOTT, 1960; QUINLIVAN, 1971).

Uma das causas que provoca o retardamento da germinação, que às vezes se prolonga por vários anos, é o próprio tegumento das sementes, cuja capa externa é constituida de células impermeabilizadas por deposição de suberina. Qual quer fator que destrua a impermeabilidade do tegumento permite de imediato a germinação (BURKART, 1952).

CAMERON (1967a) observou em S. humilis H.B.K.. que altas temperaturas do solo contribuem para o declínio do grau de dureza da semente e a época da colneita exerce influén cia tanto no grau de dureza como no índice de germinação. Oㅡ servou também que o maior índice de germinação de sementes em 
S. humizis H.B.K. ocorre em uma temperatura superior a $25^{\circ} \mathrm{C}$ e inferior a $30^{\circ} \mathrm{C}$. Isto foi confirmado por HOLM (1973) e BOGDAN (1977) .

Em laboratório, para quebrar a dorméncia, são $\underline{u}$ sados diversos processos: escarificação, submersão em ácido sulfúrico, ação do calor.seco, pressão hidráulica, imersão em nitrogénio líquido $\left(-196^{\circ} \mathrm{C}\right)$, segundo PHIPPS (1973).

Amostras de sementes de S. guianensis (Aubl.) Sw., colnidas diretamente de plantas e submetidas a diferentes períodos de umidade, calor seco e temperaturas alternantes, variam na germinação de 4 a $90 \%$ (BROLMANN, 1973). A maior ocorréncia de germinação se dá quando as sementes são expostas a calor seco (mäximo de $50^{\circ} \mathrm{C}$ a $70^{\circ} \mathrm{C}$ e mínimo de $15^{\circ} \mathrm{C}$ a $25^{\circ} \mathrm{C}$ ) no pe ríodo de 2 semanas a partir do início da germinação. Baixas temperaturas foram favoráveis à quebra da dorméncia quando precedidas de um pequeno tratamento a calor seco. PATERNIANI e MARTINS (1979), em laboratório, constataram em 10 populações de S. guianensis (Aubl.) Sw., provenientes dos estadọs de São Paulo, Pará e Argentina, que todas apresentaram maior germinação a $20^{\circ} \mathrm{C}$ ou a temperaturas alternantes $30 / 20^{\circ} \mathrm{C}$ e $35 / 20^{\circ} \mathrm{C}$. De maneira geral, todas as populações apresentaram maior germinação sob regime de temperatura alternante. Temperaturas acima de $35^{\circ} \mathrm{C}$ inibiram acentuadamente a germinação TULEY (1968) acrescenta que as diferenças na coloração das sementes estão associadas a diferenças na germinação, sendo que as sementes claras 
germinam mais rapidamente que as escuras.

\subsection{Número de Cromossomos}

Na tribo Hydesareae, a qual pertence ao gênero Stylosanthes Sw., foram encontrados números haplóides 7, 8, 9, 10, 11, 14, 18 e 20, confirmando a grande heterogeneidade da tribo (BURKART, 1952).

A maioria dos autores consultados concorde em afirmar que o número básico de cromossomos da sub-família Papilionoideae é $n=8$. Se esta hipótese for válida, isto leva à constatação de que dentro da tribo ocorrem diferentes níveis de ploidia. Esta variação pode ocorrer em todo o comple mento somático, que seria o caso das espécies que possuem o nú mero de cromossomos múltiplos exatos do número haplóide: 16 , 32, etc., ou epenas adição ou perda de um ou vários cromossomos do genoma básico representado por espécies aneuplóides, exemplo: 9, 11, 12, etc.

No gēnero Stylosánthes sw., em relação ao nümero de cromossomos, existe um número reduzido de trabalhos. Os poucos que existem parecem demonstrar que a maioria das espécies estudadas possuem número básico de cromossomos $x=10$. CAMERON (1967), através do estudo do número de cromossomos de 10 espécies de Stylosanthes sw., encointrou diplóides $2 n=20^{\circ}$, 
tetraplóides $2 n=40$, e hexaplóides $2 n=60$, concluindo que o gênero Stylosanthes sw. contém uma série de poliplóides, sendo o número básico $X=10$. Neste mesmo trabalho observou que, em bora o tamanho dos cromossomos para todas as espécies estudadas seja muito pequeno, ocorrem diferenças bem acentuadas quanto ao tamanho e forma dos cromossomos para as diferentes espécies.

KRAPOVICKAS (1957), trabalhando com 13 espécies pertencentes a 8 gèneros de leguminosas, concordou com os trabalhos de ATCHINSON (1949) e KISHORE (1951), quando estabeIece ram que o número de cromossomos do $S$. guianensis (Aubl.) Sw. é $2 n=20$ e com RICHARD (1.964) que determinou o $n^{\circ}$ de cromossomos de S. humilis H.B.K. como sendo $2 n=20$. Observou que há um crescimento gradual no tamanho dos cromossomos do $S$. humilis H.B.K. para S. guianensis (Aubl.) Sw. Esta caracteristica diferencial in dica que o S. humilis H.B.K. é de origem mais recente, quando comparado com S. guianensis (Aubl.) Sw. e S. montevidensis Vog., que são considerados mais primitivos por possuirem o cariötipo com índice assimétrico mais aperfeiçoado, indicando uma especialização maior na espécie.

Em um estudo desenvolvido pelo CIAT (1977), usando ponta da raiz para contagem de cromossomos em $S$. capitata Vog., obtiveram resultados inconsistentes. Alguns ecotipos apresentaram número de cromossomos $2 n=20$, porém, outros ecotipos parecem ser tetraplóides com $2 n=40$ cromossomos. 
Atualmente, as espécies do gènero que possuem nümero de cromossomos contrecido são:

Espécies No de cromossomos Autor
S. guianensis (Aubl.) Sw.
$2 n=20$
KISHORE (1951)
S. humilis H.B.K.
$2 n=20$
RICHARD e GOULD ( 1964 )
S. erecta Beauv.
$2 n=60$
ANON. (1959)
S. mucronata Mohlenbrock
$2 n=40$
ANON. (1959)
S. mucronata Willd
$2 n=20$
LOVE (1978)
S. montevidensis Vog.
$2 n=40$
KRAPOVICKAS (1957)
S. viscosa sw.
$2 n=20$
CAMERON (1967)
S. hamata (L.) Taub.
$2 n=20$
CAMERON (1967)
S. macrocarpa Blake
$2 n=20$
CAMERON (1967)
S. tuberculata Blake
$2 n=40$
CAMERON (1967)
S. subsericea Blake
$2 n=40$
CAMERON (1967)
S. capitata Vog.
$2 n=40$
CIAT (1977)
$2 n=20$
CIAT (1977) 


\section{MATERIAL E METODOS}

\subsection{Material}

O material utilizado no trabalho constou de 7 espécies e 3 variedades do gênero Stylosanthes Sw., provenientes de diferentes regiões geográficas e ecológicas dos estados de Minas Gerais, Rio de Janeiro è Goís.

\section{Espēcies}

S. capitata Vog.

S. macrocephala M.B. Ferr et S. Costa

\section{Origem}

Itaguai, RJ

Betim, MG

S. scabra Vog.

Itaguaí, RJ

S. grandifolia M.B. Ferr. et S. Costa sT. n.

Montes Claros, MG

S. humizis H.B.K.

Mozarlàndia, GO

S. gracilis H.B.K.
Montes Claros, MG 
(continuação)

\section{Espēcies}

Origem

S. viscosa sw.

Uberaba, MG

S. guianensis (Aubl.) Sw. var. microcephala M.B. Ferr. et Santo Antonio do MonS. Costa te, $M G$

S. guianensis (Aubl.) Sw. var. canescens M.B. Ferr. et S.

Costa

Barbacena, MG

S. guianensis (Aubl.) Sw. var. vulgaris M.B. Ferr. et S. Costa Divinópolis, MG

\subsection{Métodos}

D presente trabalno foi dividido em 3 etapas: a etapa inicial conduzida na Estação Experimental do Anhembi, pertencente à Departamento de Genética da ESALQ/USP, situada no município de Piracicaba, SP, tendo como objetivo principal estimar a variabilidade entre e dentro dos diferentes taxons, aplicando a taxonomia numérica, para 19 caracteres morfológicos, vegetativos, florais e do fruto. A segunda e a terceira etapas, relativas ao estudo da germinação de sementes e determinação do número de cromossomos de cada espécie, foram.reali- 
zadas em condições de laboratório, utilizando-se as sementes produzidas na primeira etapa.

\title{
3.2.1. Preparo das Sementes e. Semeadura
}

\author{
a) Preparo das Sementes \\ As sementes utilizadas para o plantio foram sub
} metidas ao processo de escarificação manual através da utilização de lixas.

\section{b) Semeadura}

As sementes foram semeadas em caixas de $47,0 \mathrm{~cm}$ de comprimento por $38 \mathrm{~cm}$ de largura, contendo uma mistura de terra, esterco de curral, e conservadas em casa de vegetação por trinta dias. Depois, as plântulas foram repicadas para copos de papel, permanecendo ainda na casa de vegetação durante trinta dias, quando foram levadas para o campo experimental, no dia $09 / 01 / 1978$.

\subsubsection{Instalação do Experimento}

Dois meses após terem sido semeadas, as plantas foram transplantadas para o campo, tendo sido utilizado o méto do de plantas espaçadas (BURT et alii, 1971; EDYE et alii, 1973), cada planta ocupando um espaço de $4,0 \mathrm{~m}^{2}$.

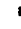

o delineamento utilizado foi o de blocos casualizados, com 12 repetições das 7 espécies e 3 variedades. Cada 
parcela foi formada por 2 plantas, ocupando uma ärea de $8,0 \mathrm{~m}^{2}$. A área experimental total foi de $1292,0 \mathrm{~m}^{2}$.

o período experimental estendeu-se da data do plantio no campo (09/01/1978) até a data da coleta dos últimos dados $(06 / 11 / 1979)$.

\subsubsection{Anālise Taxonōmica}

Em cada planta foram feitas 2-3 mensurações dos seguintes caracteres:

a) Caracteres Morfológicos Vegetativos

- comprimento do folílo central

- largura do folíalo central

- comprimento do folíolo latéral direito

- largura do folíolo lateral direito

- comprimento da estípula

- largura da estípula

- comprimento do dente

- comprimento dos internödios.

\section{b) Caracteres Morfológicos Florais}

- comprimento do estandarte

- largura do estandarte

- comprimento da asa

- largura dá asa

- comprimento do pedúnculo 
- comprimento do cálice.

\section{c) Caracteres Morfoiógicos do Fruto}

- comprimento do artículo superior

- largura do artículo superior

- comprimento do articulo inferior

- largura do artículo inferior

- comprimento do apéndice terminal

$$
\text { O material coletado foi colocado em fichas de }
$$
cartolina, submetido à prensa para secagem.

Todas as mensurações foram feitas com o auxílio de uma régua milimetrada comum, tomando sempre o ponto de maior dimensão do órgão vegetal, tanto para o comprimento como pa ra a largura.

\subsubsection{Porcentagem de Germinação das Sementes}

Foram montados 3 ensaios em laboratório para es timar a porcentagem de germinação das sementes em temperaturas

constantes de $15^{\circ} \mathrm{C}, 25^{\circ} \mathrm{C}$ e $35^{\circ} \mathrm{C}$. Cada ensaio constou de 3 repeti ções com 20 sementes cada repetição, para cada uma das 7 espécies e 3 variedades.

As sementes foram previamente tratadas com Arasan e colocadas a germinar em placas de Petri forradas com papel-filtro umidecido com água destilada e mantidas no germina- 
dor em ausência de luz, durante 15 dias. Diariamente foi fei ta a contagem e remoção das sementes germinadas em cada popula ção. $\quad$ padrão estabelecido para germinação foi na fase em que a radícula já havia sido emitida e os cotilédones já se encontravam diferenciados.

\subsubsection{Mitoses em Pontas de Raizes}

\section{Algumas sementes provenientes do material que} foi plantado no campo foram postas a germinar, em laboratório, para aproveitamento de suas radículas no estudo mítótico dos cromossomos.

As raizes foram cortadas e tratadas com hidroxí quinoleína a 0,002\% durante 2 horàs, e logo fixadas em Carnoy $3: 1$ durante 24 horas. Após este período, o material foi transferido para álcool $70 \%$ e conservado em congelador até o momento de ser utilizado.

Antes de preparar as láminas, o material foi la vado com água destilada, hidrolizado em HCl $1 \mathrm{~N}^{\circ}$ a $60^{\circ} \mathrm{C}$ durante 10 minutos e lavado novamente. Após este tratamento, foi colocado em reativo de Schiff, em frasco escuro, posto em câmara escura por 60 minutos e logo lavado em água corrente por 10 mi nutos.

\footnotetext{
o preparo das láminas foi feito colocando-se uma ponta de raíz na lámina e sobre ela uma gota de Carmin pro-
} 
piônico $1 \%$.

A raiz foi esmagada primeiramente com um bastonete de ferro; em seguida, foi colocada a lamínula sobre o ma terial e aquecida levemente na chama. 0 excesso de corante que fluiu sob a lamínula foi retirado com papel-filtro, ao mes mo tempo esmagando-se fortemente o material até ficar reduzido a uma só camada de células.

Foram preparadas làminas de raízes provenientes de sementes das 7 espécies e das 3 variedades. As láminas que apresentaram condições satisfatórias de observação microscópica foram transformadas em permanentes.

As làminas permanentes foram observadas ao microscópico para a contagem de cromossomos.

\subsubsection{Anāilise Para Avaliar as Características Morfoló gicas Vegetativas, Florais e do Fruto \\ A análise da variáncia para os caracteres morfó} lógicos foi realizada com o objetivo de estimar o grau de uniformidade de cada espécie e variedade e o grau de diversificação existente entre as espécies e entre as variedades, a par tir das amostras colhidas de cada um.

$$
\begin{aligned}
& \text { Considerou-se o seguinte modelo linear: } \\
& Y_{i j}=u+p_{i}+m_{j(i)}
\end{aligned}
$$


onde: $Y_{i j}=$ mensuração qualquer de um dado caráter, na planta i, repetição j

$u=$ média geral

$p_{i}=$ efeito da planta $i$

$m_{j(i)}=$ entre medidas dentro de cada planta.

De acordo com este modelo, a análise de variància de cada espécie separada, obedece o seguinte esquema:
F.V.
G.L.

\begin{tabular}{lc} 
Plantas $(P)$ & $P-1$ \\
Mensurações (M)/P & $(M-1) P$ \\
\hline MP -1
\end{tabular}

Para a análise conjunta da varianncia das características entre plantas dentro das espécies foi utilizado o seguinte modelo linear:

$$
Y_{i j k}=m+e_{i}+P_{j(i)}+m_{k}(i j)
$$

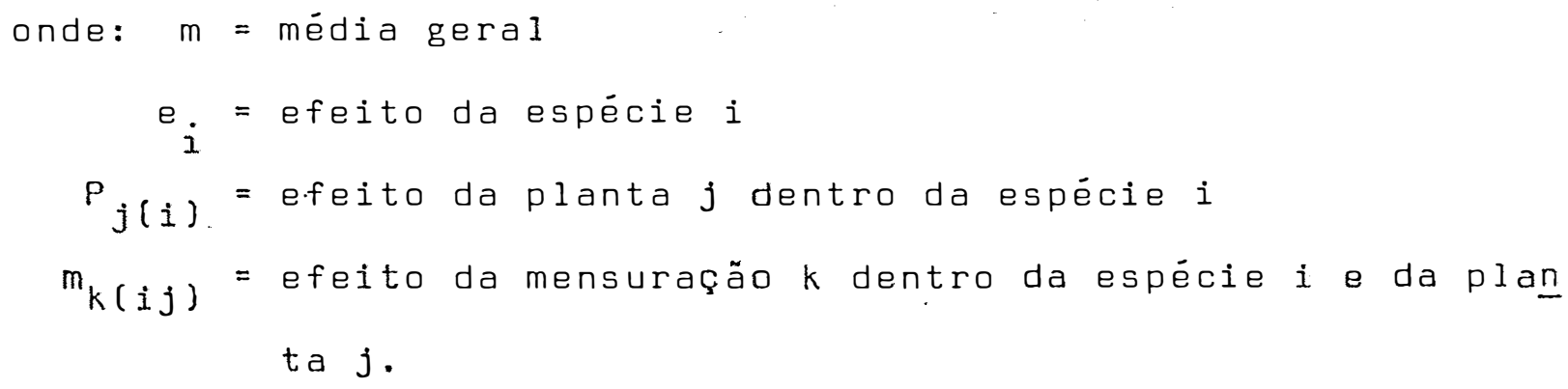


Esquema da análise:

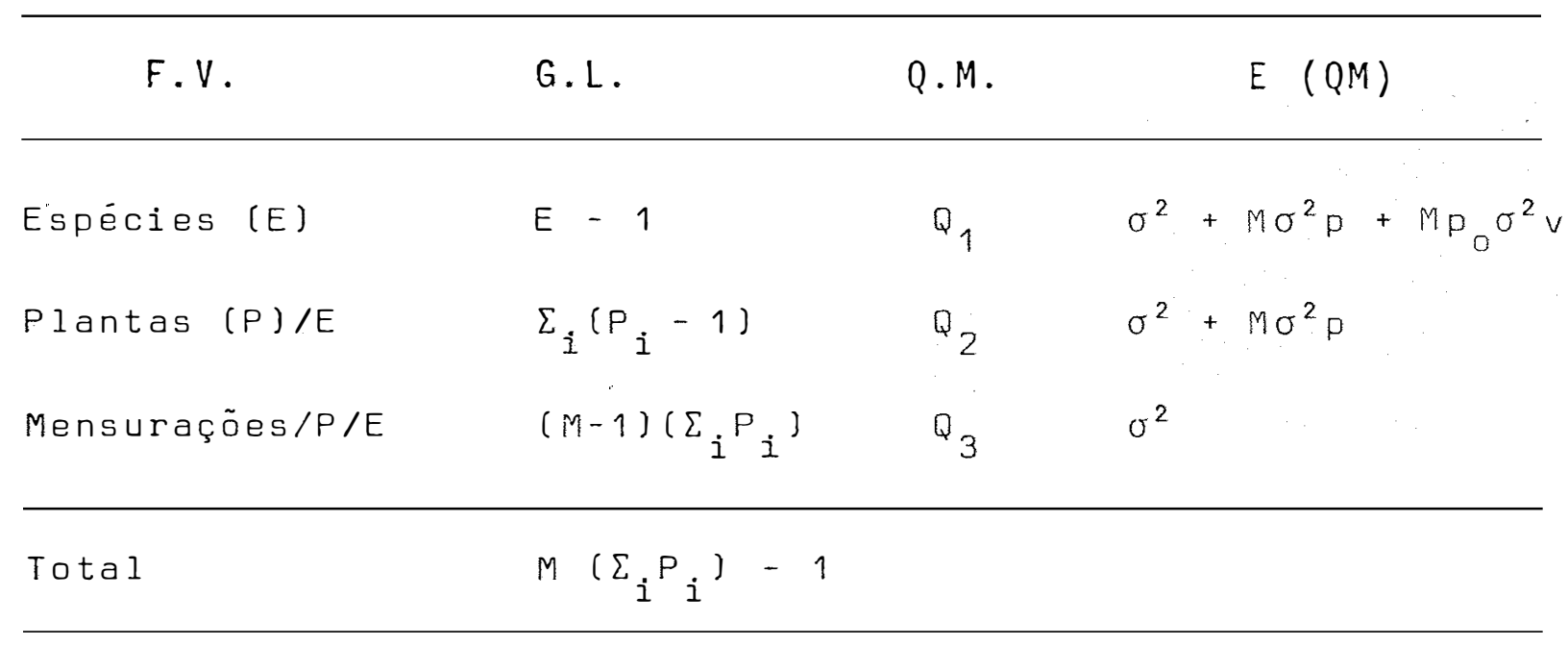

onde: mensurações/P/E = entre mensurações dentro de plantas, dentro de espécies; $M$ = número de mensurações por planta;

$P_{i}=$ número de plantas de cada espécie ( $i=$ $1, \ldots, E)$

$E^{\prime}=$ número de espécies.

Como o número de plantas de cada espécie (P) é variável, foi estimado um número médio de plantas ( $p_{0}$ ), de acordo com o processo de SNEDECOR e COCHRAN (1974).

$$
P_{0}=\frac{1}{(V-1)}\left(N-\frac{\sum_{i} P_{i}^{2}}{N}\right)
$$

Para a análise conjunta da variáncia dos carac- 
teres entre plantas dentro das espécies, os dados das 3 variedades: microcephala, canescens e vulgaris foram computados como uma única espécie de $S$. guianensis (Aubl.) Sw.

$$
\text { Para análise da variáncia dos caracteres entre }
$$
plantas dentro das 3 variedades, utilizou-se o seguinte esquema:

\begin{tabular}{|c|c|c|c|}
\hline$F . V$. & G.L. & Q.M. & $F$ \\
\hline Variedades (V) & $v-1$ & $Q_{1}$ & $Q_{1} / Q_{2}$ \\
\hline Plantas $(P) / V$ & $\sum_{i}\left(P_{i}-1\right)$ & $Q_{2}$ & $Q_{2} / Q_{3}$ \\
\hline Mensurações/P/V & $(M 1)\left(\sum_{i} P_{i}\right)$ & $Q_{3}$ & \\
\hline Total & $M\left(\Sigma_{i} P_{i}\right)-1$ & & \\
\hline
\end{tabular}

- Com as médias de cada caráter, foram construídos gráficos comparativos entre as 7 espécies e 3 variedades, segundo o esquema de polígonos (BENSON, 1962). 


\title{
4. RESULTADOS
}

\author{
4.1. Anālise da Variāncia das Mensurações dos Caracteres \\ Os quadrados médios obtidos das mensurações pa- \\ ra 8 caracteres vegetativos, 6 caracteres florais e 5 caracte- \\ res do fruto, de 8 espécies do gènero Stylosanthes Sw. acham- \\ se nas Tabelas 1,2 e 3 . Observa-se nestas tabelas que todos \\ os caracteres analisados, em conjunto, das espécies, apresenta \\ ram uma alta significància para o efeito dos mesmos, aos ní- \\ veis de $1 \%$ e $5 \%$, o que indica a existéncia de considerável va- \\ riação genética entre as espécies.
}

A análise individual dos caracteres de cada espécie também apresentaram significància, porém, diferiram conforme a espécie. De acondo com os resultados obtidos, as plan tas foram agrupadas quanto à variabilidade em:

- espécies que apresentaram significància entre plantas para a maioria dos caracteres vegetativos analisados: 
S. capitata Vog., S. scabra Vog., S. humiZis H.B.K. e S. visco sa Sw. (Tabela 1);

- espécies que apresentaram significáncia entre plantas para metade dos caracteres vegetativos analisados: $S$. grandifolia M.B. Ferr. et Sousa Costa (Tabela 1);

- espécies que apresentaram significáncia entre plantas para a maioria dos caracteres florais analisados: $\quad S$. macrocephala M.B. Ferr. et Sousa Costa, S. humizis H.B.K. e S. viscosa Sw. (Tabela 2);

- espécies que apresentaram significáncia entre plantas para metade dos caracteres tilorais analisados: S. cap $\underline{i}$ tata Vog. e S. scabra Vog. (Tabela 2);

- espéciés que apresentaram significáncia entre plantas para apenas um caráter floral analisado: S. grandifoZia M.B. Ferr. et Sousa Costa (Tabela 2);

- espécies que apresentaram significáncia entre plantas para todos os caracteres do fruto analisados: $S$. macro cephaza M.B. Ferr. et Sousa Costa (Tabela 3);

- espécies que ajpesentaram significància entre plantas para dois caracteres do fruto analisados: S. gracizis H.B.K. (Tabela 3); 
- espécies que apresentaram significáncia entre plantas apenas para um caráter do fruto analisado: S. capitata Vog. e S. grandifolia M.B. Ferr. et Sousa Costa (Tabela 3 ).

Os resultados obtidos para verificar semelhanças e diferenças entre 3 variedades de $S$. guianensis (Aubl.) Sw.: microcephala M.B. Ferr. et Sousa Costa, canescens M.B. Ferr. et Sousa Costa e vuZgaris M.B. Ferr. et Sousa Costa, mos traram significáncia estatística entre plantas, aos níveis de $1 \%$ e $5 \%$ para a maioria dos 8 caracteres vegetativos ( Tabela 4), 6 caracteres florais (Tabela 5 ) e 2 caracteres do fruto (Tabela 6) analisados.

Os caracteres que não apresentaram significància estatística entre plantas nas mensurações foram: largura do folílo central (Tabela 4), comprimento do estandarte (Tabe la 5), comprimento do cálice (Tabela 5) e largura do fruto (Tabela 6).

Na Tabela 7 encontram-se.as médias de cada carä ter, em cada espécie, que foram utilizadas pará a construção de gráficos comparativos. As plantas foram agrupadas conforme o esquema de divisões: Secção I, Stylosanthes (Figuras 1 e 2), compreendendo: S. capitata Vog., S. macrocephala M.B. Ferr. et Sousa Costa e S. scabra Vog., e Seção II, Astyposanthes (Figuras 3 e 4), compreendendo: S. grandifolia, M.B. Ferr. et Sousa Costa,.S. humilis H.B.K., S. gracilis H.B.K. e. viscosa 
Sw., e as 3 variedades de $S$. guianensis (Aubl.) Sw.: microcephaZa M.B. Ferr. et Sousa Costa, canescens M.B. Ferr. et Sousa Costa e vulgaris M.B. Ferr. et Sousa Costa (Figuras 5 e 6).

$$
\text { Foi representado também o peso de } 100 \text { sementes }
$$
de cada espécie e de cada variedade (Tabela 7 e Figuras 2, 4 e 6). 


\subsection{Biologia da Semente}

No estudo da biologia da semente, determinou-se a porcentagem de dorméncia, em condições dé laboratório, através da condução de 3 ensaios, levando em consideração apenas o fator temperatura.

As Tabelas $8.1 ., 8.2$. e 8.3. mostram os resulta dos dos ensaios com sementes de 7 espécies e 3 variedades do gênero Stylosanthes Sw. Os 3 ensaios foram mantidos no germinador, na auséncia de luz, durante 15 dias, com temperaturas diferentes para cada ensaio.

Na Tabela 8.1. e Figura 7 constam os dados do ensaio com temperatura constante a $15^{\circ} \mathrm{C}$. Todas as es pécies e variedades apresentaram uma alta porcentagem de dorméncia, refletindo uma variabilidade extremamente baixa, sendo que S. capitata Vog. e S. grandiflora M. B. Ferr. et Sousa Costa, nestas condições, apresentaram 100\% de dor mència.

Entre as espécies; as que demonstraram menor porcentagem de dorméncia, ou seja, maior índice germinativo,.foram: S. humilis H.B.K. e S. guianensis (Aubl.) Sw. variedade canescens M.B. Ferr. et Sousa Costa.

Os resultados. do ensaio mantido a uma temperatu ra constante de $25^{\circ} \mathrm{C}$, estão na Tabela 8.2. e na Figura 8 . Sob 
estas condições, as espécies e as variedades também continua ram com alta porcentagem de dorméncia, sendo que a $S$. capitata Vog . continuou $100 \%$ dormente e as espécies que apresentaram menor dorméncia foram: S. viscosa sw., 83,38\%, a S. guianensis (Aubl.) Sw. variedade canescens M.B. Ferr. et Sousa Costa, com $83,36 \%$

Sob temperatura constante de $35^{\circ} \mathrm{C}$ (Tabela 8.3 e Figura 9), as espécies continuaram com baixa porcentagem de germinação, sendo o maior índice apresentado pela $S$. viscosa Sw. $\operatorname{com} 16,64 \%$.

\subsection{Nümero de Cromossomos}

O número de cromossomos resultantes da contagem de metáfases mitóticas nas 7 espécies e 3 variedades do gênero Stylosanthes Sw. se encontra na Tabela 9.

0 número básico de cromossomos das espécies foi
considerado como sendo aquele que ocorreu em $97 \%$ das mitoses
observadas, tendo em vista certa dificuldade na contagem
nítida dos cromossomos em algumas metáfases, pelo fàto
dos mesmos serem de tamanho muito pequeno.

A análise destas làminas revelou que a maioria 
das espécies e variedades em estudo apresentaram $2 n=20$ cromossomos, com exceção de S. capitata Vog. e S. scabra Vog. que possuem $2 n=40$ cromossomos. As 3 variedades de $S$. guianensis (Aubl.) Sw.: microcephala M.B. Ferr. et Sousa Costa, canescens M.B. Ferr. et Sousa Costa e vulgaris M.B. Ferr. et Sou sa Costa, e as espécies S. humizis H.B.K., S. viscosa sw. e S. capitata Vog. condizem com o número de cromossomos determinado anteriormente por outros autores. A $S$. capitata Vog. com $2 n=40$, provavelmente é um tetraplóide, como já foi encon trado em ecotipos, num trabalho de fitomelhoramento feito pela CIAT, em 1977. 


\section{DISCUSSAO}

\subsection{Anālise da Variāncia das Mensurações dos Caracteres}

De acordo com os resultados apresentados nas

Tabelas 1, 2 e 3 , podemos afirmar que as espécies possuem um e levado grau de variabilidade em seus caracteres, concordando com LEITÃO FILHO e LOVADINI (1974), quando apresentam as espécies do gênero Stylosanthes $\mathrm{Sw}$. dotadas de um acentuado polimorfismo em diferentes caracteres, sendo grande a variação entre e dentro das espécies, devido a fatores genéticos e adaptä ções ao meio. O mesmo foi confirmado por BARRos (1978) em $S$. guianensis (Aubl.) Sw. e BARRIGA (1979) em S. humilis H.B.K., onde os caracteres avaliados exibiram uma grande variabilidade entre e dentro das populações estudadas. Estas variações caracterizam a individualidade de cada espécie, facilitando, nes te ponto, a sistemática tradicional para a classificação das mesmas. 
da S. capitata Vog. (Tabelas 1, 2 e 3) mostraram ser uma espécie que possui apenas alguns caracteres significativos para a variabilidade: comprimento e largura do folílo central, comprimento e largura do folíolo lateral direito, comprimento e largura do dente, largura da asa, comprimento do pedúnculo e comprimento do apèndice terminal. Porém, é uma espécie muito promissora como forrageira, por possuir uma série de características a gronómicas importantes e uma variação bastante significativa de ecotipos, segundo informe anual do CIAT (1977).

S. macrocephala M.B. Ferr. et Sousa Costa é uma espécie que no campo se distingue das demais devido ao tamanho da inflorescéncia ser bem maior que as demais espécies. FERREIRA e SOUSA COSTA (1979) denominaram-na de macrocephala baseados no tamanho da inflorescéncia. Possui grande variabili dade genética, pois todos os caracteres vegetativos, florais e do fruto apresentaram significáncia aos níveis $1 \%$ e 5\%, na aná lise individual da espécie (Tabela 1, 2 e 3), com exceção do caráter comprimento do pedúnculo da flor, que não mostrou significància. Esta é uma das espécies na qual o lomento não possui 2 articulações, sendo considerada ausente a articulação inferior.

A espécie S. scabra Vog., pelos resultados da a nálise individual, parece apresentar maior variabilidade acumula da nos caracteres vegetativos (Tabelas 1,2 e 3 ), pois apenas 2 deles nao demonstraram significància: comprimento dos internó- 
dios e largura da estípula. Nos caracteres florais, entre os 6 analisados, 3 foram significativos apenas a nível 1\%, enquan to que 3 não apresentaram significáncia. 0 mesmo aconteceu com os caracteres, do fruto, 3 foram significativos a nível 1\% e 3 não foram significativos. Os resultados do nosso trabaIho condizem com os trabalhos de MOHLENBROCK (1958) e FERREIRA e SOUSA costa (1979), que ao descreverem a espécie, concordaram com a existéncia dos mesmos caracteres, porém, varian do nas medidas de alguns deles, como comprimento, largura e ta manho. LEITÃo E LOVADINI (1974) mencionam S. scabra Vog. co mo uma espécie que possui variação menor em alguns caracteres morfológicos quando comparada a outras espécies.

A espécie S. grandifolia M.B. Ferr. et Sousa Costa foi aquela que apresentou menor variabilidade em todos os caracteres mensuráveis analisados, quando comparada com as demais espécies estudadas neste trabalho, discordando de FERREIRA e SOUSA COSTA (1979), que a situa como uma espécie que apresenta grande variabilidade. Por outro lado, MOHLENBROCK (1958) descreveu-a como uma variedade, S. guianensis robusta, por apresentar diferenças morfológicas bastante acentuadas em alguns caracteres, como folílos grandes, caules robustos, inflorescéncias e flores bem maiores que as demais espécies. O fato desta espécie destacar-se das demais por. apre sentar um elevado grau de desenvolvimento morfológico em seus caracteres, não significa possuir grande variabilidade acumula da, pois os resultados estatísticos da análise individual da 
espécie (Tabelas 1, 2 e 3) mostraram significáncia apenas para alguns caracteres como largura do folílo central, comprimento da estipula, largura do estandarte e comprimento do artículo inferior do fruto.

Na espécie S. humizis H.B.K. , apesar do compri mento dos internódios, comprimento do estandarte, comprimento do cálice da flor e comprimento do apéndice terminal do fruto serem caracteres que não apresentaram significáncia quanto à variabilidade, na análise individual (Tabelas 1, 2 e 3 ), os de mais caracteres confirmaram ser uma espécie dotada de grande variabilidade, conforme os trabalhos de BURT et a $i$ i (1971), os quais detectaram ampla variabilidade intra-especifica. Nesta espécie, como na espécie S. macrocephala M.B. Ferr. et Sousa Costa, ocorreu a inexistência do artículo inferior do lomento, discordando dos trabalhos de BARRIGA (1979), que encontrou frü tos bi-articulados. Estas controvérsias comprovam a existência de uma grande variabilidade que existe neste caráter dentro da espécie.

A espécie S. gracilis H.B.K. apresentou significáncia na análise individual aos níveis $1 \%$ e $5 \%$, para todos os caracteres vegetativos (Tabela 1), para a maioria dos caracteres florais (Tabéla 2), com exceção do comprimento do pedúnculo e comprimento do cálíce da flor. Porém, quanto ao fruto, apresentou pouca variação, sendo apenas significativos os cä racteres comprimento do artículo superior e comprimento do ar 
tículo inferior (Tabela 3).

A espécie S. viscosa Sw. é representada por caracteres de tamanho bastante reduzido, folílolos pequenos, atin gindo o máximo de $25 \mathrm{~mm}$, estípulas, brácteas e flores muito re duzidas. E uma espécie notável no campo, de fácil distinção, pelo fato de possuir seus caracteres morfológicos bem menores quando comparada com as demais espécies. Porém, possui uma elevada significáncia de variabilidade em todos os caracteres mensuráveis estudados. Concordando com fERREIRA e SOUSA CosTA (1979), quando constataram a grande diversificação nos caracteres da espécie e admitiram ter sido a causa de várias sinonímias. Em todos os caracteres estatisticamente analisados na espécie, apenas não foram significativos comprimento dos in ternódios, comprimento do cálice e largura do artículo inferior do fruto. Os demais caracteres mostraram significáncia aos níveis $1 \%$ e $5 \%$ (Tabelas 1,2 e 3 ).

Observando os resultados das Tabelas 1,2 e 3 , verificamos que S. gracilis H.B.K., S. macrocephala M.B. Ferr. et Sousa Costa, S. humizis H.B.K. e S. viscosa Sw. destacam-se das demais espécies por apresentarem maior variabilidade em to dos os caracteres, vegetativos, florais e do fruto. As outras espécies também apresentaram umà considerável variação, embora de intensidades diferentes, conforme o caráter. A $S$. capitata Vog. e a S. scabra Vog. possuem uma maior variabilidade nos caracteres vegetativos, um pouco menor nos caracteres florais, 
divergindo, porém, nos caracteres do fruto, pois enquanto $S$. scabra Vog. apresenta acentuada variabilidade, em S. capitata Vog. apenas um caráter é significativo. São duas espécies que guardam uma considerável semelhança em seus caracteres quantitativos, podendo ser uma indicação de uma relação fil loge nética na história das mesmas. Enquanto S. grandifolia M. B. Ferr. et Sousa Costa destaca-se por ser uma planta viçosa, a presentando diferenças morfológicas bastante acentuadas na ma oria de seus caracteres morfológicos e pouca variabilidade em seus caracteres mensuráveis, S. viscosa sw. é representada por caracteres morfológicos bastante pequenos, porém, dotada de uma grande variabilidade em seus caracteres mensuráveis. Es te fato porerá ser, de uma certa forma, um indicador de duas espécies bem distanciadas na escala evolutiva, quanto à estabi lidade como espécies. Assumindo esta hipótese, $S$. viscosa Sw. é uma espécie bastante recente, que ainda se encontra longe do ponto máximo de desenvolvimento de seus caracteres e está mais próxima ao ancestral, enquanto que, S. grandifolia M.B. Ferr. et Sousa Costa está mais próxima ao ponto máximo de desenvolvimento e diferenciação de seus caracteres, consequentemente, mais distanciada do ancestral.

Nas Figuras $1,2,3$ e 4, nas espécies 5 . capitá ta Vog., S. macrocephala M.B. Ferr, et Sousa Costa, S. scabra Vog., S. humilis H.B.K. e S. gracilis H.B.K., observa-se que a distribuição dos caracteres vegetativos, florais e do fruto se guem linhas uniformes de distribuição; embora conservando bem 
nítida a variabilidade individual. Isto porém, não acontece com as espécies $S$. viscosa Sw. e S. grandifolia M.B. Ferr. et Sousa Costa, pois a distribuição dos caracteres segue linhas divergentes, sendo bem acentuadas quando comparadas entre si e entre as demais espécies, dando a impressão de serem duas espé cies limites extremos dos caracteres mensuráveis estudados.

As 3 variedades de S. guianensis (Aubl.) Sw.: microcephala M.B. Ferr. et Sousa Costa, vulgaris M.B. Ferr. et Sousa Costa e canescens M.B. Ferr. et Sousa Costa, além de apresentarem diferenças em seus caracteres morfológicos e agronómicos, como tamanho e tipo de espiga, hábito da planta, tama nho do folíolo central, cor das folhas, período e duração da floração, que foram os principais caracteres que serviram de base para FERREIRA e SOUSA COSTA (1979) classificá-las como va riedades, ampla variabilidade na maioria de seus caracteres mensuráveis estudados (Tabelas 4,5 e 6). Na análise conjunta, os dados revelaram que apenas os caracteres largura do folíolo central, comprimento do cálice, entre plantas dentro de variedades não foram significativos e o caráter largura do artículo também não foi significativo entre as variedades. Os. demais caracteres todos foram significativos aos níveis $1 \%$ e $5 \%$. Nas Figuras 5 e 6 observa-se que nas 3 variedades todos os caracte res seguem a mesma linha de distribuição, porém, conservando bem nítida a variabilidade dos mesmos em cada variedade. Tudo indica que estas variedades estejam sofrendo processo gradual de diferenciação . 
Entre todas as plantas analisadas, um caráter que merece atenção é a ocorréncia de 1 ou 2 artículos no lomento. Este caráter é encontrado na secção I Stylosanthes, na secção II Astyposanthes e nas 3 variedades de S. guianensis (Aubl.) Sw. Nas plantas analisadas da $S$. crocephala M.B. Ferr. et Sousa Costa (Tabela 3), o lomento é formado apenas por uma articulação, porém, fERREIRA e SouSA COSTA (1979), na descrição da espécie, apresentaram o lomento com duas articulações férteis. Na S. humilis H.B.K., os resultados que se encontram na Tabela 3 concordam com MOHLENBROCK (1958), que descreveu o lomento com uma só articu lação, porém, BOGdAN (1977) e BARRIGA (1979) encontraram frutos bi-articulados. Além de existir uma grande variabilidade neste caráter dentro das espécies, é ao mesmo tempo um caráter adaptativo que as espécies desenvolveram ao longo dos tempos em função de sobrevivência, adaptação ao meio e dispersão, como é o caso do S. humilis H.B.K., que apresenta o lomento com um apéndice terminal bem desenvolvido e enrolado, exercendo provavelmente importante papel na distribuição espacial da espécie, pela aderéncia ao pelos dos animais (BOGDAN, 1977).

Na tentativa de diferenciar espécies de variedades através dos dados obtidos, criamos um problema no estabelecimento de critérios diferenciais entre as mesmas, pois todos os caracteres mensuráveis apresentaram grande variabilidade. Podemos afirmar, combase nos dados, que e- 
xiste uma analogia entre os mesmos quanto à variação, cuja finalidade principal consiste numa maior probabilidade de encontrar um ambiente seguro para seu estabelecimento e.desenvolvimento.

Elevado potencial de variabilidade genética é um fator muito promissor em plantas forrageiras para futuros trabalhos de melhoramento, pois a grande variabilidade genética apresentada por esses caracteres e, consequentemente, menor influéncia ambiental, indicam considerável capacidade de adaptação a diversidades ambientais, podendo ser espécies indicadas para pastagens em díferentes situações climáti cas, solos e altitudes e, ao mesmo tempo, obter com facili dade, cultivares com ótimas características forrageiras, pro dução satisfatória, elevado potencial de resisténcia às doenças, pragas, etc.

\subsection{Biologia da Semente}

Referente aos estudos de germinação e dorméncia das sementes, pouemos observar, pelos dados, que a porcentagem de dorméncia para todas as espécies e variedades estudadas, nas très condições de temperaturas, foi bastante alta, a- 
tingindo uma média de $90,19 \%$ a $15^{\circ} \mathrm{C}, 90,53 \%$ a $25^{\circ} \mathrm{C}$ e $91,36 \%$ a $35^{\circ}$. C. Consequentemente, ocorreu uma taxa de germinação extremamente baixa durante o período de 15 dias.

Temperaturamostrou exercer influēncia bastante grande na germinação, referente ao comportamento e resposta de cada espécie aos diversos níveis térmicos.. Em temperaturas mais elevadas, a germinação iniciou-se antes. Assim, a $15^{\circ} \mathrm{C}$ a germinação iniciou-se 6 dias. após a semeadura, alćançando o maior índice germinativo no $10^{\circ}$ e no $14^{\circ}$ dias (Figura 7). Enquanto que, a $25^{\circ} \mathrm{C}$, a germinação iniciou-se no $2^{\circ}$ dia, com índi ces mais elevados no $2^{\circ}$ e $3^{\circ}$ dias (Figura 8). As sementes das espécies mantidas no germinador a $35^{\circ} \mathrm{C}$ iniciaram a germinação um dia após a semeadura, tendo seu maior índice germinativo no $2^{\circ}$ dia (Figura 9).

\section{Estabelecendo comparação com trabalhos feitos} em S. humilis H.B.K., CAMERON (1967a) observou que o maior índi ce de germinação das sementes ocorre em temperatura superior a $25^{\circ} \mathrm{C}$ e inferior a $30^{\circ} \mathrm{C}$, e BARRIGA (1979), que considerou temperaturas ideais para a germinação da espécie $20^{\circ} \mathrm{C}$ a $25^{\circ} \mathrm{C}$, já que todas as populações atingiram os mais altos. índices nestas condições. Os nossos resultados demonstraram maior índice germina tivo a $15^{\circ} \mathrm{C}$. 0 mesmo aconteceu comparando $S$. guianensis(Aubl.) Sw., onde PATERNIANI e MARTINS (1979), em laboratório, constatou, em 10 populações desta espécie, que todas apresentaram maior germinação a $20^{\circ} \mathrm{C}$, enquanto que, nos nossos dados 
(Tabelas 8.1, 8.2 e 8.3), maior índice germinativo das médias das 3 variedades de $S$. guianensis (Aubl.) Sw. ocorreu na tempe ratura a $15^{\circ} \mathrm{C}$.

Diante do comportamento das especies e varieda-

des, para o fator ambiental temperatura, podemos afirmar que $\underline{e}$ xiste um considerável grau de variabilidade retido em cada uma delas.

Um fator de considerável importáncia para germi nação é a permeabilidade do tegumento à água. A quantidade e o grau de impermeabilidade, segundo ROLSTON (1978), define a dureza da semente. Sendo assim, as sementes das espécies do gènero Stylosanthes $\mathrm{Sw}$. são consideradas duras, pois de acordo com BURKART (1952), o tegumento é uma estrutura homogènea bas tante impermeável. Este fato é comprovado quando são feitas comparações entre sementes escarificadas e sementes não escari ficadas. A diferença é acentuadámente superior na primeira em relação a segunda.

O conhecimento da herança de sementes duras auxiliará os melhoristas de plantas na determinação dos cruzamen tos apropriados para aumentar ou diminuir a taxa de impermeabi lidade à água, dependendo dos objetivos do programa de melho ramento.

O elevado grau de dormência evidenciado para to 
das as espécies e variedades se constitui em um poderoso mecanismo de sobrevivéncia desenvolvido pelas mesmas. Deste modo, formam um banco de reserva de sementes viáveis acumuladas no solo, germinando apenas quando as condições são favoráveis, garantindo desta maneira a manutenção das gerações subsequentes, diante da diversidade de condições ambientais.

Acreditamos que um miaior conhecimento neste cam po de pesquisa, com maior número de dados sobre o assunto, pro porcionará melhores esclarecimentos dos processos evolutivos na germinação, bem como poderão fornecer subsídios de cada espécie.

Outro caráter importante que se destacou nos e므 saios de germinação foi a cor das sementes. Para as espécies que possuem sementes de várias cores, as que germinaram em 1 o lugar foram as mais claras. Esta constatação veio afirmar o que TUley (1968) observou em S. guianensis (Aubl.) Sw., que as diferenças na coloração estão associadas a diferenças na germi nação. As sementes mais claras germinam mais rapidamente.

\subsection{Número de Cromossomos}

Os resultados obtidos na contagem do número de cromossomos reforçam os trabalhos de CAMERON (1967) no estudo de 10 espécies de Stylosanthes Sw., onde conclui que o gènero 
contém uma série de poliplóides, sendo o número básico $x=10$. Embora o tamanho dos cromossomos para todas as espécies seja pequeno, ocorrem diferenças bem acentuadas quanto ao tamanho e forma para as diferentes espécies.

RICHARD (1964) diz que o tamanho dos cromossomos, quando comparado entre as diferentes espécies, bem como o índice de simetria dos mesmos, são características diferenciais, indicando a origem mais remota ou mais recente e o grau de especialização das espécies. O próprio autor nesta ocasião, faz referéncia ao tamanho dos cromossomos e o índice assimétri co das espécies de S. humilis H.B.K., S. guianensis (Aubl.)Sw. e S. montevidensis Vog., afirmando ser a S. humizis H.B.K. uma espécie mais recente que as $S$. guianensis (Aubl.) Sw. e $S$. montevidensis Vog. pelo fato da primeira possuir cromossomos menores e com simetria menos graduada que as outras duas espécies. Isto foi confirmado pelo trabalho de CAMERON (1967) so bre nūmero de cromossomos e morfologia de algumas espécies de Stylosanthes Sw., onde aparecem as figuras dos cariótipos destas espécies. O mesmo foi observado no nosso trabalho, na contagem dos cromossomos, onde S. grandifolia M.B. Ferr. et Sou sa Costa e S. gracilis H.B.K. revelaram os cromossomos de tama nho acentuadamente maior em relação às demais espécies, embora não tenha sido feita a identificação de cada cromossomo do con junto, nem a distinção entre os genomas.

No estudo do nümero de cromossomos, tamanhos, 
formas, semelhanças, diferenças e ploidias, pode-se estabelecer, se na evolução das espécies ocorreram hibridações ou introgressões e também e mais fácil determinar o possível ou os possiveis ancestrais comuns, que e um fator fundamental na classificação das espécies.

Portanto, tornam-se indiscutiveis os benefícios do conhecimento dos cromossomos na biossistemătica, a fim de poder melhor tornar compreensiveis os mecanismos que levaram à formação de cariótipos diferentes e, consequentemente, à origem das espécies. 


\section{CONCLUSOES}

Os resultados obtidos, analisados e discutidos no presente trabalho, permitiram as seguintes conclusões:

(a) existe uma grande variabilidade genética dentro de cada espécie e variedade e entre as espécies e varie dades para todos os caracteres mensuráveis vegetativos, florais e do fruto, indicando considerável capacidade de adaptação a diferentes ambientes, podendo ser espécies indicadas para pastagens em diferentes situações climátićas, solos e altitudes;

(b) a análise dos caracteres pelo emprego da Ta xonomia Numérica permite uma distinção mais nítida das espécies, possibilitando estabelecer com mais clareza as linhas evolutivas do gênero;

(c) a ocorrência de acentuada semelhança entre os caracteres quantitativos de $S$. capitata Vog. e S. scabra 
Vog. e o fato de possuírem o mesmo nümero de cromossomos 2 n 40, indica grande identidade filogenética.

(d) pelo fato de S. grandifolia M.B. Ferr. et Sousa Costa apresentar um elevado grau de desenvolvimento morfológico em seus caracterés e pouca variabilidade genética, é uma espécie que já atingiu um certo grau de estabilidade;

(e) S. viscosa sw. é uma espécie bastante recen te, com grande variabilidade em todos os seus caracteres vege- tativos, florais e do fruto;

(f) as variedades microcephala, canescens e vuI garis apresentaram grau de variabilidade tão amplo quanto aque le observado dentro e entre as diferentes espécies, consequentemente não permitindo estabelecer um critério diferencial entre espécies e variedades;

(g) o dimorfismo exibido peilo lomento com 1 ou 2 artículos, encontrados nas diferentes espécies e variedades, sugere que, além de ser um caráter adaptativo, os grupos taxonómicos semelhantes estão filogeneticamente relacionados;

(h) o forte grau de dormència evidenciado nas sementes das 7 espécies e 3 variedades, caracteriza as semen tes do tipo duras, bem como constitui um mecanismo de sobrevivência altamente vantajoso, pelo fato de mantê-las no solo durante o período em que as condições ambientais são desfavo- 
ráveis à germinação e desenvolvimento da plàntula;

(i) as 7 espécies e 3 variedades do gênero StyLosanthes Sw., quanto ao número de cromossomos, são poliplóides do número básico $x=10$, sendo $S$. capitata Vog. e S. scabra Vog. tetraplóides com $2 n=40$ e as demais espécies e varie dades, diplóides, $\operatorname{com} 2 \pi=20$. 


\section{LITERATURA CITADA}

ATCHINSON, E., 1949. Studies in the Leguminosae IV. Chromosome numbers and geographical relationships of miscellaneous Leguminosae. Journal Elisha Mitchell Sci. Soc., 65(1): 112.

BARRIGA, J.P., 1979. Autoecologia de stylosanthes humilis H.B.; : avaliação da variabilidade morfológíca e estudos da biologia da semente. Piracicaba, ESALQ/USP, 97 p. (Dissertação de Mestrado).

BARROS, L.M., 1978. Avaliação da variabilidade de caracteres agronómicos em populações de Stylosanthes guianensis (Aubl.) Sw. Piracicaba, ESALQ/USP, $108 \mathrm{p}$. (Dissertação de Mestrado).

BENSDN, L., 1962. Plant taxoriomy. Methods and Principles. The Ronald Press Company. New York. p. 494.

BENTHAM, [., 1859. Leguminosae. In Martius C.F.P., Flora 
Brasiliensis. Verlag Von J. Cramer. V. 15, Pars I, p. $88-94$.

BOGDAN, A.V., 1977. Tropical pasture and fodder plants (Grasses and Legumes). Longman, London and New York. $475 \mathrm{P}$.

BROLMANN, J.B., 1973. Progeny studies in Stylosanthes guianensis (Aubl.) Sw. Proc. Soil and Crop science Society of Florida, Belle Glade, 33: 22-24.

BURKART, A., 1952. Las leguminosas argentinas silvestres e cultivadas. ACME AGENCY, Soc. de Resp. Ltda. Suipacha 58 , Buenos Aires. p. 193-285.

BURT, R.L.; L.A. EDYE; W.T. WILLIAMS; B. GROOF e C.H.L. NICHOLSON, 1971. Numerical analysis of variation patterns in the genus Styrosanthes as an aid to plant introduction and assessment. Australian Journal of Agricultural Research, Melbourne, 22 : $737-757$.

CAMERON, D.F., 1967. Chromosome number and morphology of some introduced Stylosanthes species. Australian Journal of. Agricultural Research, Melbourne, 18: 375-379.

CAMERoN, D.F., 1967a. Herdseedness and dormency of Townsville lucerne (stylosanthes humizis H.B.K.) selections. Australian dournal of Experimental Agriculture and Animal Husbandry, 
$7: \quad 237-248$

CAMERON, D.F., 1967b. Flowering in Townsville lucerne (Stylosanthes humilis H.B.K.). 1 - Studies in controlled environments. Australian Journal of Experimental Agriculture and Animal Husbandry, 7: 489-494.

CAMERON, D.F., 1967c. Flowering in Townsville lucerne (Stylosanthes humilis H.B.K.J. 1 - The effect of latitude and time of the flowering time of single plants. Australian Journal of Experimental Agriculture and Animal Husbandry, $7: 495-500$.

CAMERON, D.F., 1967d. Flowering time and the natural distribution and dry matter production of Townsville lucerne (Stylosanthes humilis H.B.K.) populations. Australian Journal of Experimental Agriculture and Animal Husbandry, 7: 501-508.

CIAT. Informe Anual. 1977. Fitomelhoramento. A-14 - A-16.

DON, G., 1832. Gen. Syst., 2: 281-1832.

DUCKE, A., 1959. Notas adicionais às Leguminosas da Amazōnia Brasileira. Bol. Téc. 36. Inst. Agron. Norte, 45-75.

EDYE, L.A.; R.L. BURT; W.T. WILLIAMS; R.S. WILLIAMS E B. GROOF, 1973. A preliminary agronomic evaluation of Stylosanthes 
species. Australian Journal of Agriculture Research, Melbourne, 24(4): $511-525$.

EDYE, L.A. E O.F. CAMERON, 1975. Comparison of Brazilian and naturalized Australian ecotypes of Stylosanthes humilis H.B.K. in the dry tropics of Quensland. Australian Journal of Experimental Agriculture and Animal Husbandry, 15(72): $8-87$.

HOLM, A. MCR., 1973. The effect of high temperature pretreatments on germination of Townsville Stylosanthes seed material. Australian Journal of Experimental Agriculture and Animal Husbandry, 13(63): 190-192.

HUTCHINSON, J., 1964. The genera of flowering plants. Dicotyledones, Vol. I. Clarendon Press, Oxford. 516 pp.

KISHORE, H., 1951. A note on the chromosome numbers of some plants. Indian Journal Genetics and Plant Breedding, 11(2): 217.

KRAPOVICKAS, A. E A.M. FUCHS DE KRAPOVICKAS, 1957. Notas citológicas sobre leguminosas. Revista de Investigaciones Agricolas, XI (3).

LEITÃo FILHO, H.F. e L.A.A.C. LOVAOINI, 1974. Cunsiderações sobre o género Stylosanthes Sw. Campinas, SP. Instituto Agronômico. Boletim Técnico $n^{8} 10.12 \mathrm{p}$. 
LOVE, A., 1978. IOPB Chromosome number reports LXI. Taxon. Journal of the International Association for Plant Taxonomy, 27(4): 375-392.

MANNETJE, L.T., 1977. A revision of varieties of Stylosanthes guianensis (Aubl.) Sw. Australian Journal of Botany, Melbourne, 25: $347-362$.

MOHLENBROCK, R.H., 1958. A revision of the genus Stylosanthes. History of the genus. Annals of Missouri Botanical Garden, St. Louis, 44: 299-355.

MOHLENBROCK, R.H., 1963. Further considerations in Stylosanthes (Legurinosae). Rhodora, 65: 245-259.

PATERNIANI, M.L.S. e P.S. MARTINS, 1979. V̀ariabilidade genética da dorméncia de sementes em populações de Stylosanthes guianensis (Aubl.) Sw. (Leguminosae Papilionoideae). Re Zatório Cientifico n! 13. Departamento de Genética, ESALQI USP. P. $226-234$.

PHIPPS, R.H., 1973. Methods of increasing the germination percentage of some tropical legumes. Tropical Agriculture, Trinidad, 50(4): 291-296.

QUINLIVAN, B.J.., 1971. Seed coat impermeability in legumes. Journal Australian Inst. Dynamics of Agric. Science, 10: $283-701$ 
RICHARD, A.J. e K.F. GOULD, 1964. Chromosome numbers in some introduced and indigenous legumes and grasses. Div. Trop. Pastures Tech. Pop., 2 (CSIRO) Australia, $1-18$

ROLSTON, M.P., 1978. Water impermeable seed dormancy. The Botanical Review, 44: 365-396.

SANTHIRASEGARAM, K., 1975. El potencial para la producción de ganado de carne en America Tropical: pradeiras, tropicales mejoradas a base de leguminosas forrajeiras. CIAT, series CE, $\quad \Pi^{\circ} 10, P \cdot 45-47$.

SNEDECOR, G.W. e W.G. COCHRAN, 1973. Statistical methods. 6a. ed. Ames, The Iowa State University Press. P. 593.

FERREIRA, M.B. e N.M. SOUSA COSTA, 1979. o gênero stylosantes Sw. no'Brasil. EPAMIG. 108 p.

TULEY, P., 1968. Stylosanthes gracilis. Herbage Abstracts. Farham Royal, 38: 87-94.

WILLIAMS, W.A. e J.R. ELLIOTT, 1960. Ecologićal significance of seed coat impermeability to moisture in crimson, subterraneam type climate. 41: 733-742.

WILLDENOW, C., 1800. Species Plantarum, 3: 1166. 
$-88-$

$$
\text { A PENDIC E }
$$




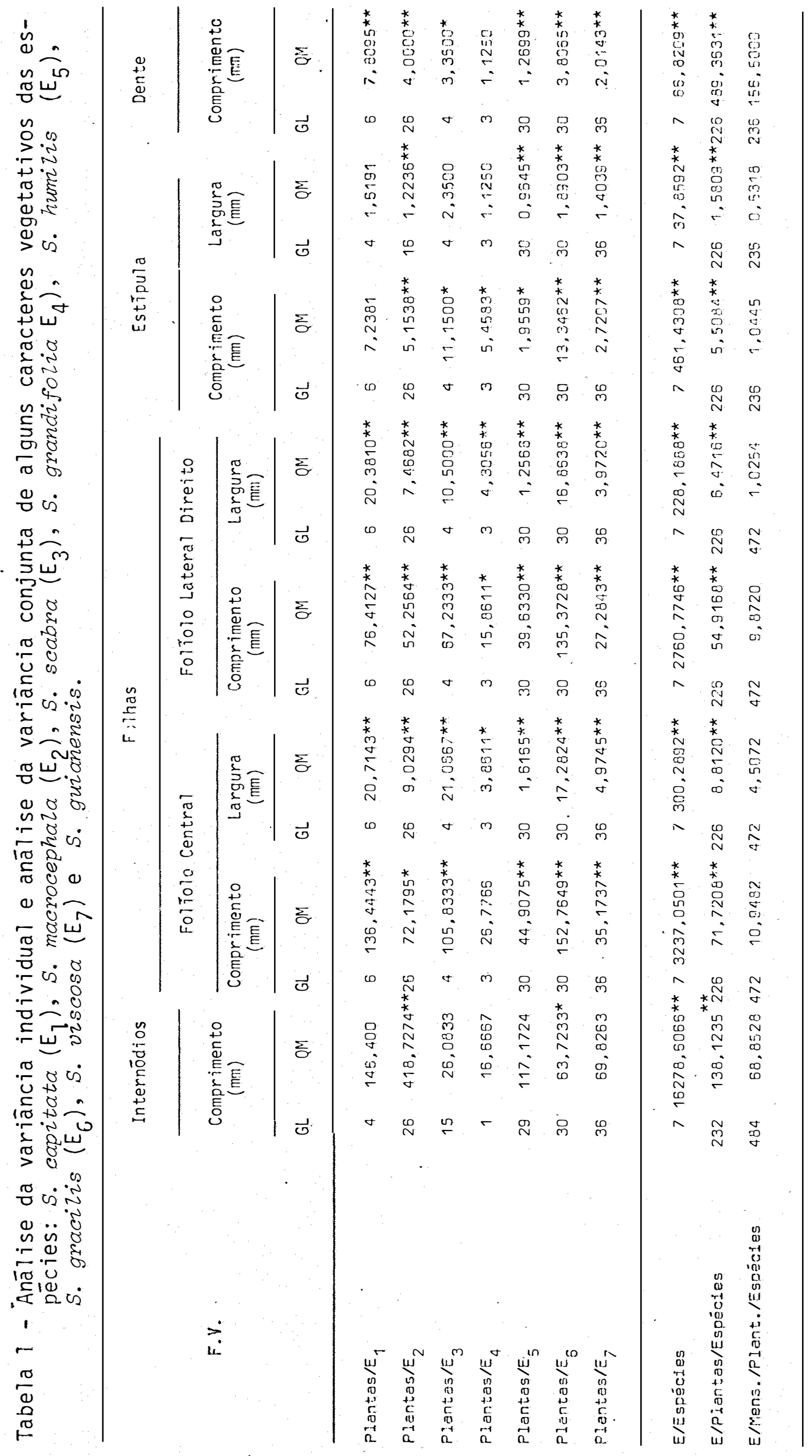




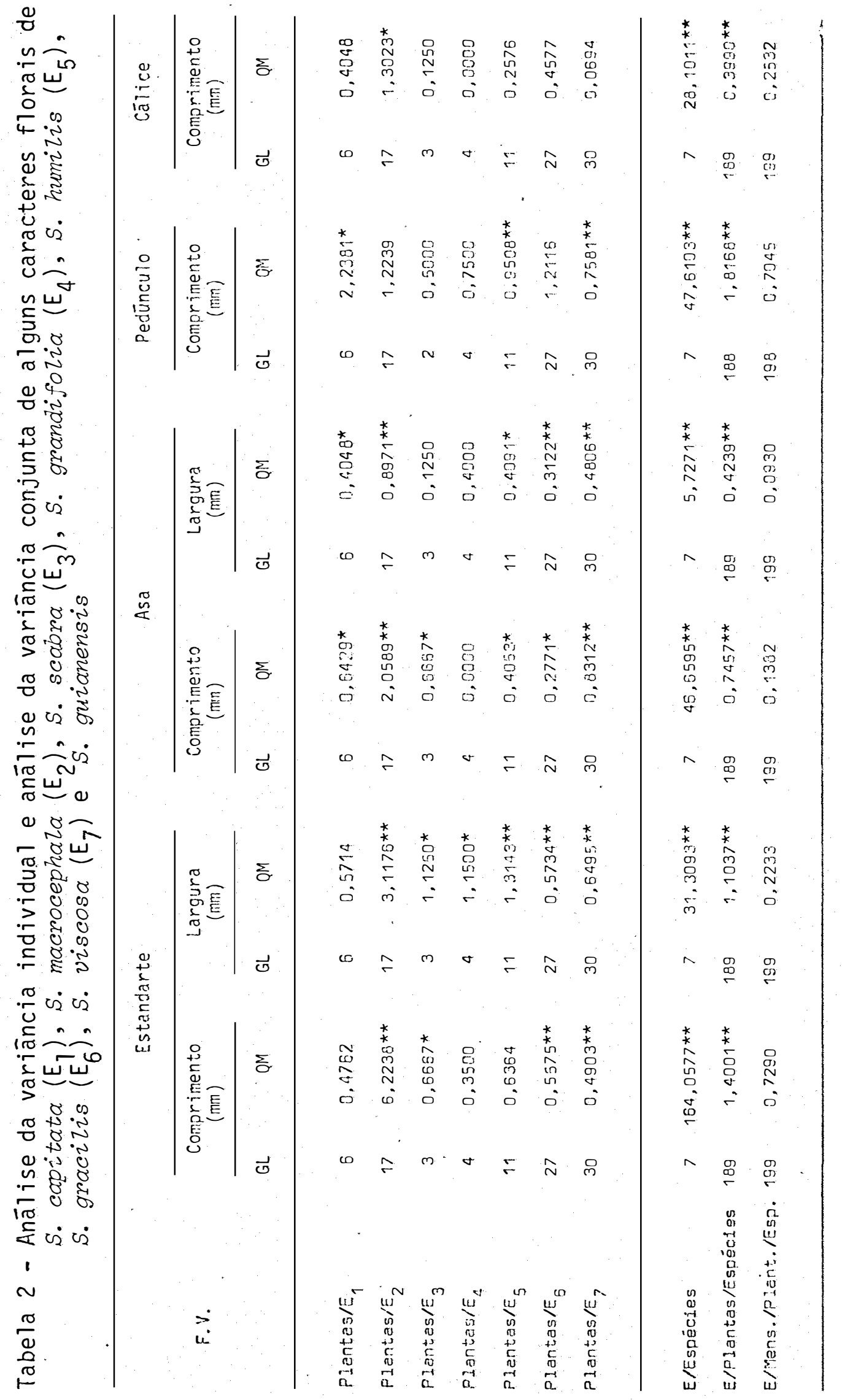




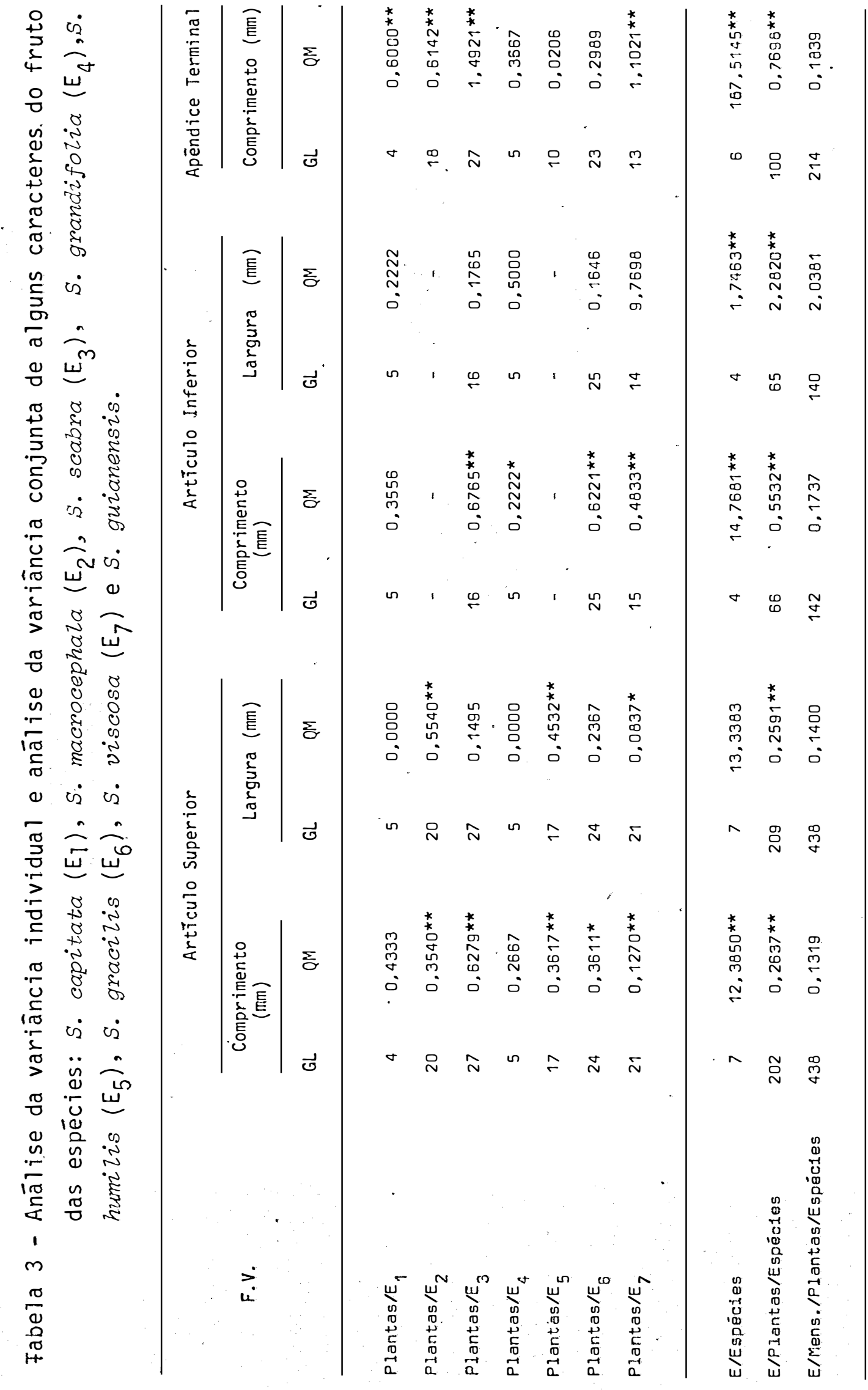




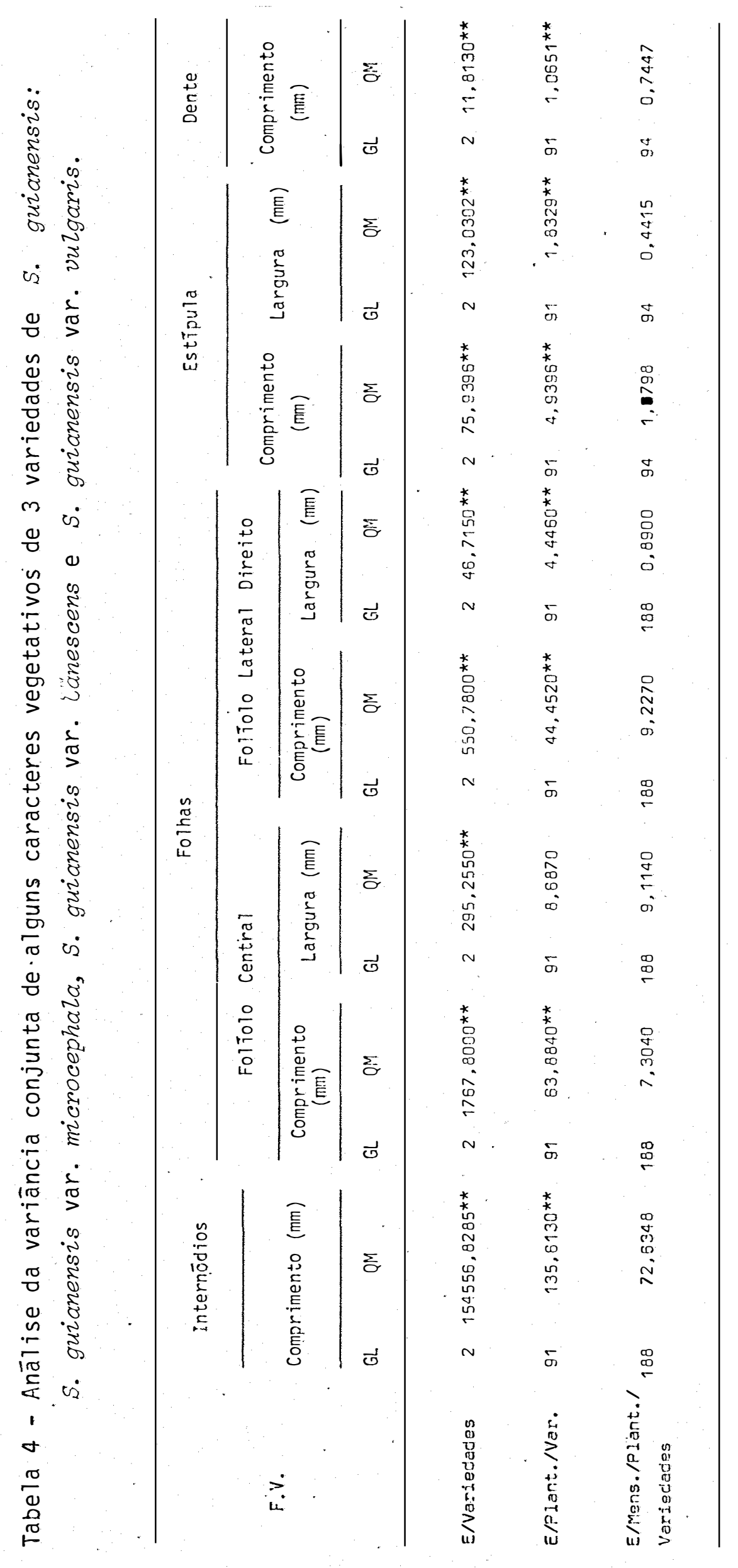

$-92$ 


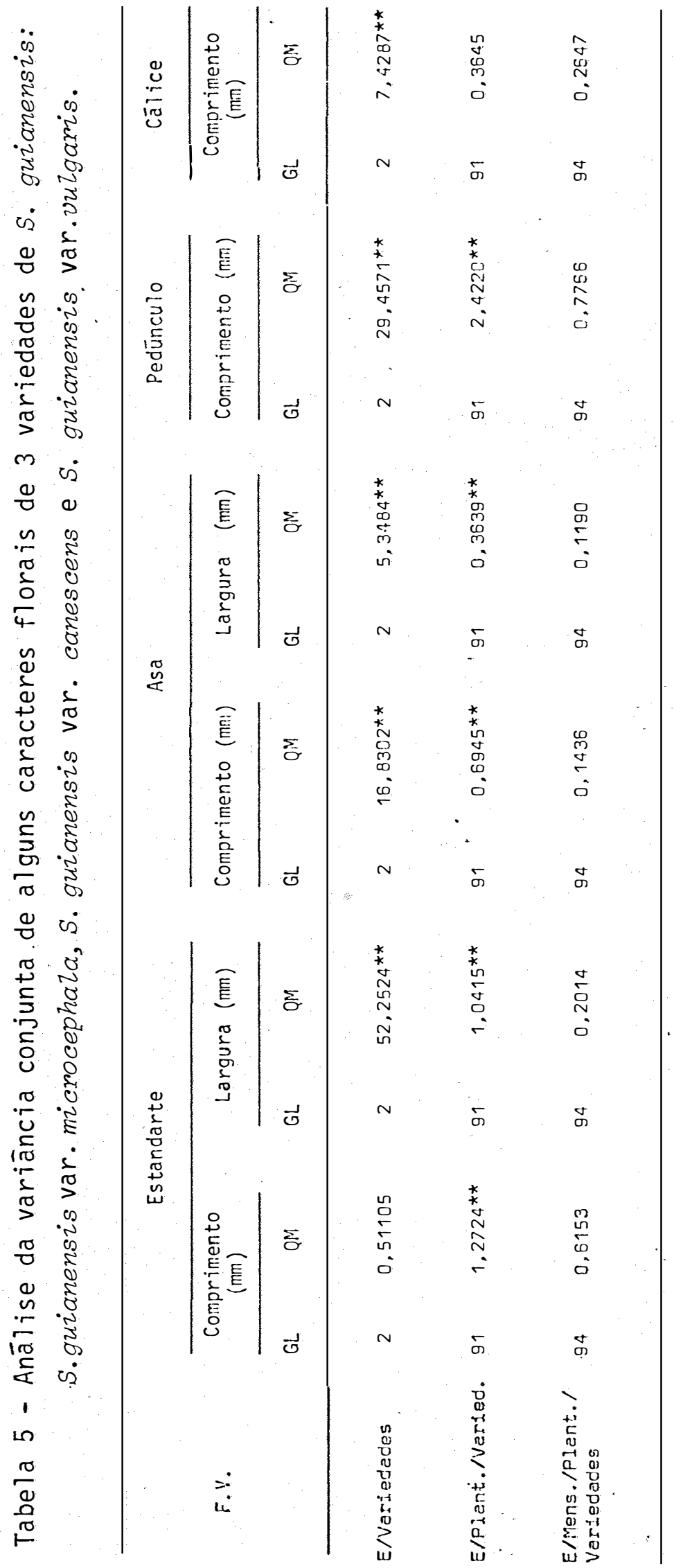


Tabela 6 - Anālise da variāncia conjunta de alguns caracteres do fruto de 3 variedades do S. guianensis: S. guianensis var. microcephala, S. guianensis var. canescens e s. guianensis var. vulgaris.

\begin{tabular}{|c|c|c|c|c|}
\hline \multirow{3}{*}{$F . V}$. & \multicolumn{4}{|c|}{ articulo } \\
\hline & \multicolumn{2}{|c|}{ comprimento (mm) } & \multicolumn{2}{|c|}{ largura $(\mathrm{mm})$} \\
\hline & GL & GM & $G L$ & GM \\
\hline E/variedades & 2 & $12,1157 * \star$ & 2 & 0,6470 \\
\hline E/PIant. /Varied. & 91 & $0,1158 * *$ & 91 & $0,2627 * \star$ \\
\hline E/Mens. /Plant/Var. & 188 & 0,0780 & 188 & 0,1702 \\
\hline
\end{tabular}




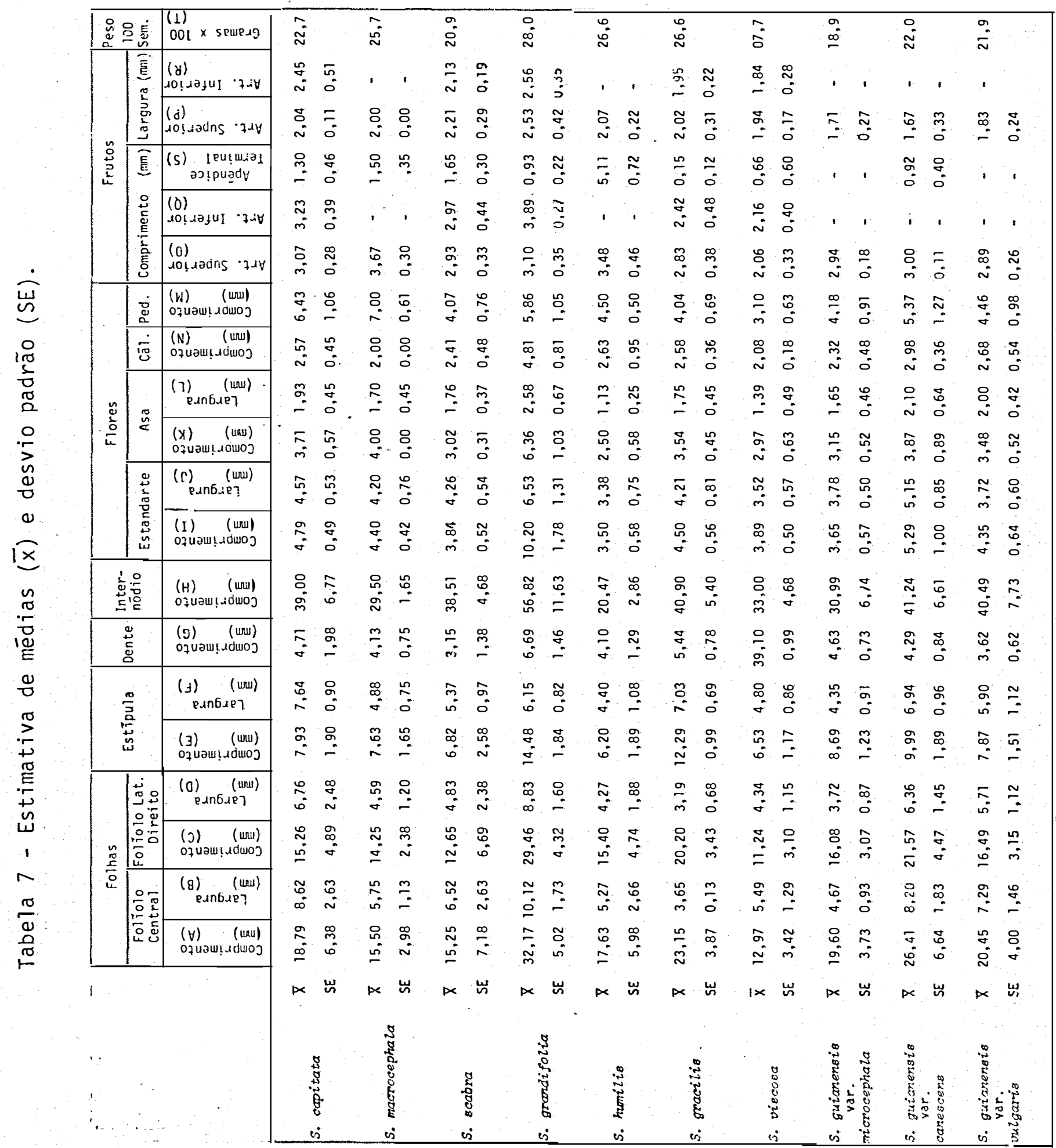


Tabela 8 - Porcentagem de dorméncia das sementes de 7 espëcies e 3 variedades de Stylosanthes Sw., en 3 ensaios de germinaçào, duronte 15 dias:

\subsection{Temperatura Constante $15^{\circ} \mathrm{C}$}

\begin{tabular}{lc}
\hline Espécies e Variedades & Porcentage:i de Dorméncia \\
\hline S. capitata (1) & 100,00 \\
S. macrocephala (2) & 80,37 \\
S. scabra (3) & 98,31 \\
S. grandifolic (4) & 100,00 \\
S. humilis (5) & 78,37 \\
S. gracitis (5) & 85,04 \\
S. viscosa (7) & 96,67 \\
S. guianensis var. microcephala (8) & 95,02 \\
S. guianensis var. canescens (9) & 76,69 \\
S. guianensis var. vulgaris (10) & 83,38 \\
\hline
\end{tabular}

8.2. Temperatura Constante $25^{\circ} \mathrm{C}$

$\begin{array}{lr}\text { S. capitata (1) } & 100,00 \\ \text { S. macrocephala (2) } & 85,05 \\ \text { S. scabra (3) } & 96,67 \\ \text { S. grandifolia (4) } & 96,68 \\ \text { S. humitis (5) } & 91,69 \\ \text { S. gracilis (8) } & 88,37 \\ \text { S. viscosa (7) } & 83,38 \\ \text { S. guianensis var. microcephat.a (8) } & 91,69 \\ \text { S. guicinensis vär. canescens ( }(3) & 83,36 \\ \text { S. guianersis var. vulgaris (10) } & 88,37\end{array}$

8.3. Temperatura Constante $35^{\circ} \mathrm{C}$

S. capi.tata (1)

S. macrocephala (2)

S. scabra (3)

S. grandifolia (a)

S. humilis (5)

S. gracilis (6)

S. viscosa (7)

S. guimensis var. miterocephaza (8)

S. guianensis var. cancescens (9)

S. guianensis var. vulgaris (10)
93,36

93,35

83, 36

93,34

85,03

86,70

83,36

98,34

88,37

93,35 
Tabela 9 - Número de cromossomos obtidos pela contagem de metā fases mitóticas ao microscópio, de células de ponta de raiz de 7 espécies e 3 variedades do gēnero Stylosanthes SW.

\begin{tabular}{ccc}
\hline Espécies & Nọ de metāfases & Nọ de cromossomos \\
e & mitóticas & $(2 n)$ em cada \\
observadas & metăfase \\
\hline
\end{tabular}

S. capitata Vog.

S. macrocephala M.B. Ferr. et Sousa Costa

S. scabra Vog.

S. grandifolia M.B. Ferr. et Sousa Costa

S. humizis H.B.K.

S. gracilis H.B.K.

S. viscosa Sw.

S. guianensis (Aubl.) Sw. var. microcephala M.B. Ferr. et Sousa Costa

S. guianensis (Aubl.) Sw. var. canescens M.B. Ferr. et Sousa Costa

S. guianensis (Aubl.) Sw. var. vulgaris M.B. Ferr. et Sousa Costa
45

$2 n=40$

45

47

$2 n=20$

30

$2 n=20$

40

$2 n=20$

44

$2 n=20$

45

$2 n=20$

45

$2 n=20$

45

$2 n=20$ 


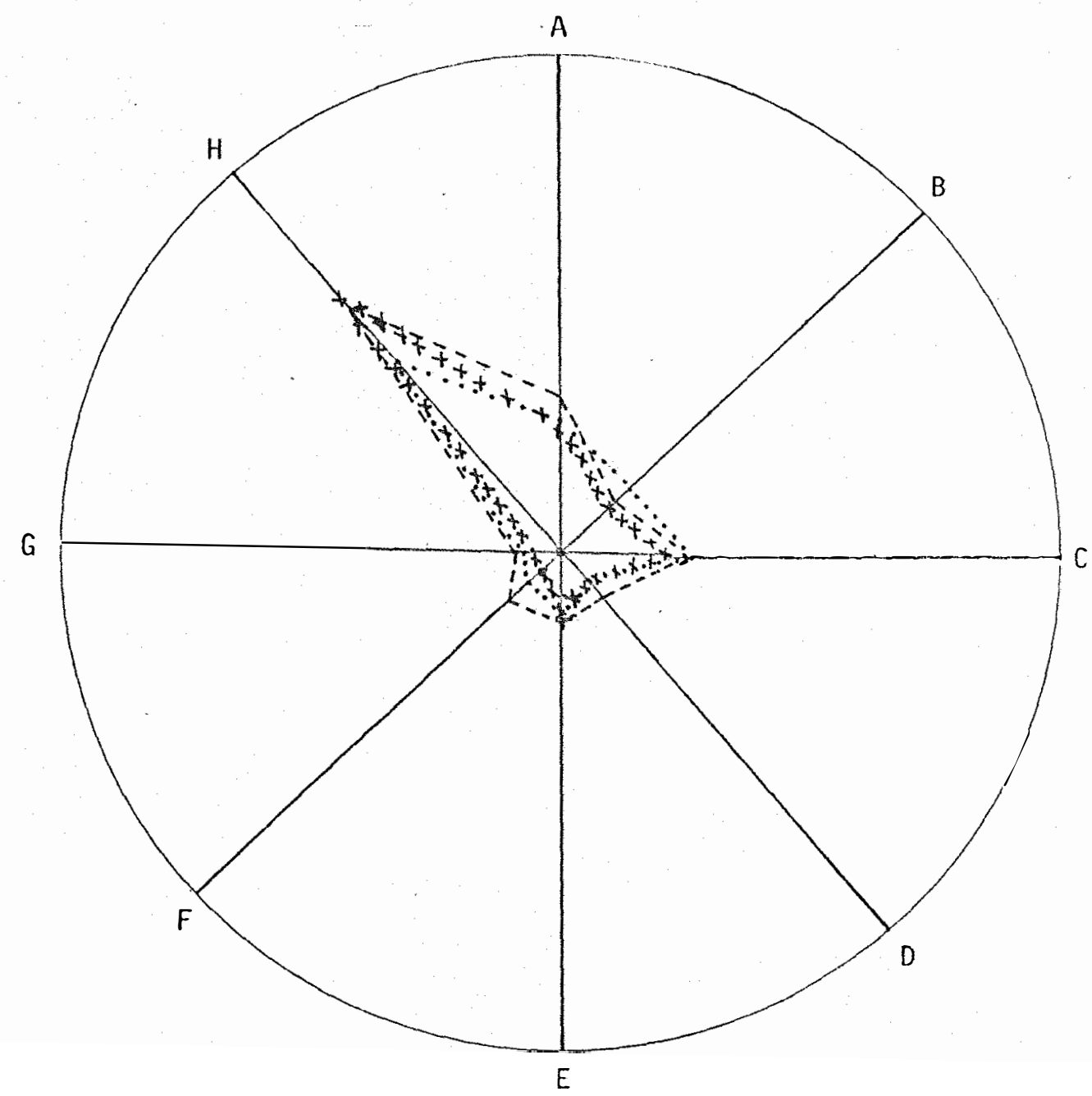

$-98-$

Escala: $1 \mathrm{~mm}$

Figura 1 - Distribuição de caracteres vegetativos: comprimento do folíolo central (A), largura do folíolo central. (B), comprimento do fo líolo lateral direito (C), largura do folíolo lateral direito (D), comprimento da estipula (E), largura da estipula (F), com primento do dente (G) e comprimento do internōdio (H), das espëcies S. capitata Vog. (-), S. macrocephaZa M.B. Ferr. et Sou sa Costa (.) e S. scabra Vog. (x). Estação Experimental de Anhembi, ESALQ/USP, Piracicaba, SP, 1981. 


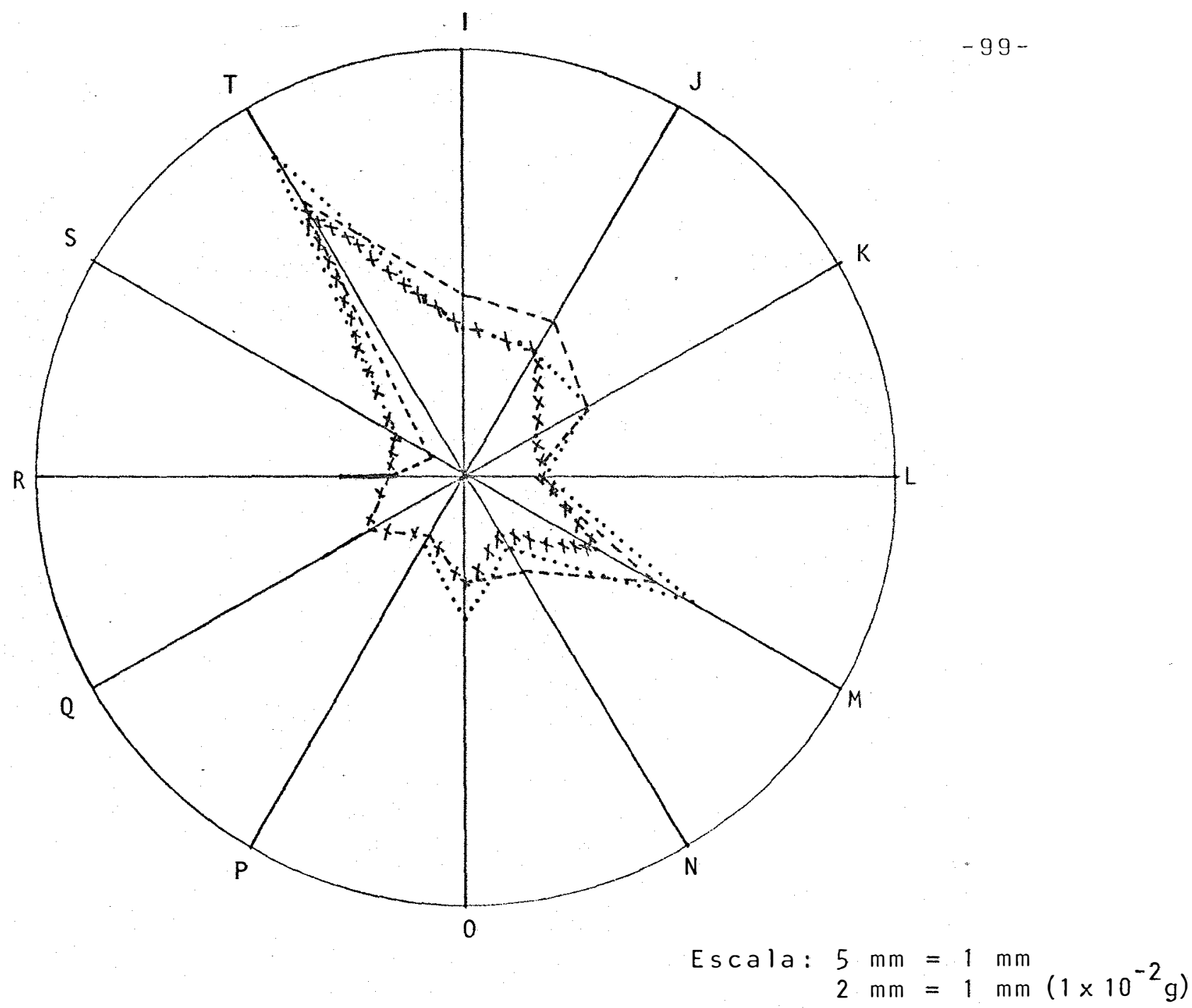

Figura 2 - Distribuição de caracteres florais e do fruto: comprimento do estandarte (I), largura do estandarte (J), comprimento da asa $(K)$, largura da asa (L), comprimento do pedūnculo (M), compri mento do cálice (N), comprimento do artículo superior do fruto $(0)$, largura do artículo superior do fruto $(P)$, comprimento do artículo inferior do fruto (Q), largura do artículo inferior do. fruto $(R)$, comprimento do apêndice terminal (S) e peso de 100 sementes (T), das espécies $S$. capitata Vog. (-), S. macrocephala M.B. Ferr. et Sousa Costa (.) e S. scabra Vog. (x). Estação Experimental de Anhembi, ESALQ/USP, Piracicaba, SP, 1981. 


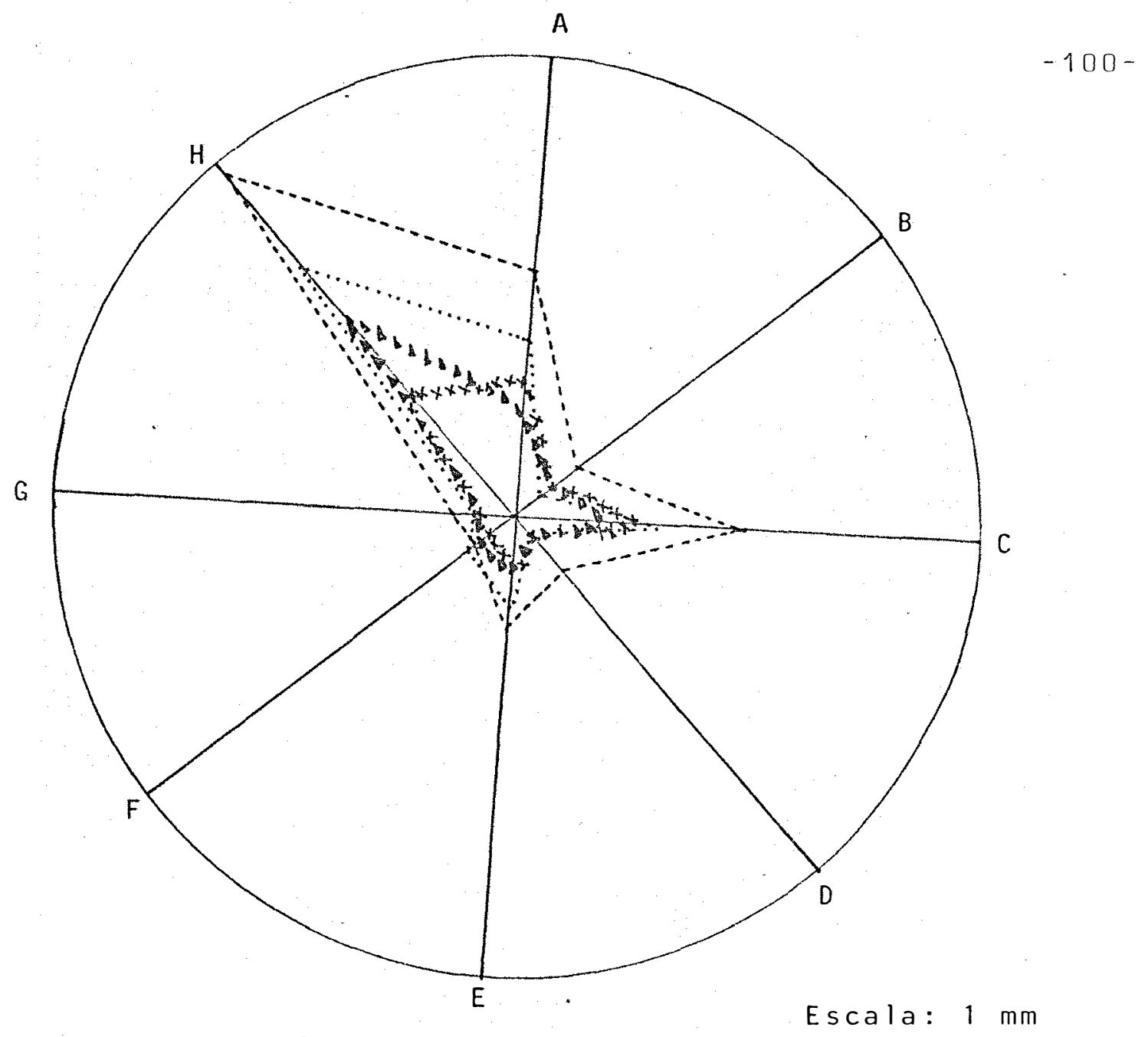

Figura 3 - Distribuição de caracteres vegetativos: comprimento do folíolo central (A), largura do folíolo central (B), comprimento do fo. lílo lateral direito (C), largura do folíolo lateral direito (D), comprimento da estipula (E), largura da estipula (F), com primento do dente (G) e comprimento do internódio $(H)$, das espēcies S. grandifolia M.B. Ferr. et Sousa Costa (-), S. hunilis H.B.K. (x), S. gracilis H.B.K. (.) e S. viscosa Sw. (A). Estação expe -imental de Anhembi, ESALQ/USP, Piracicaba, SP, 1981. 


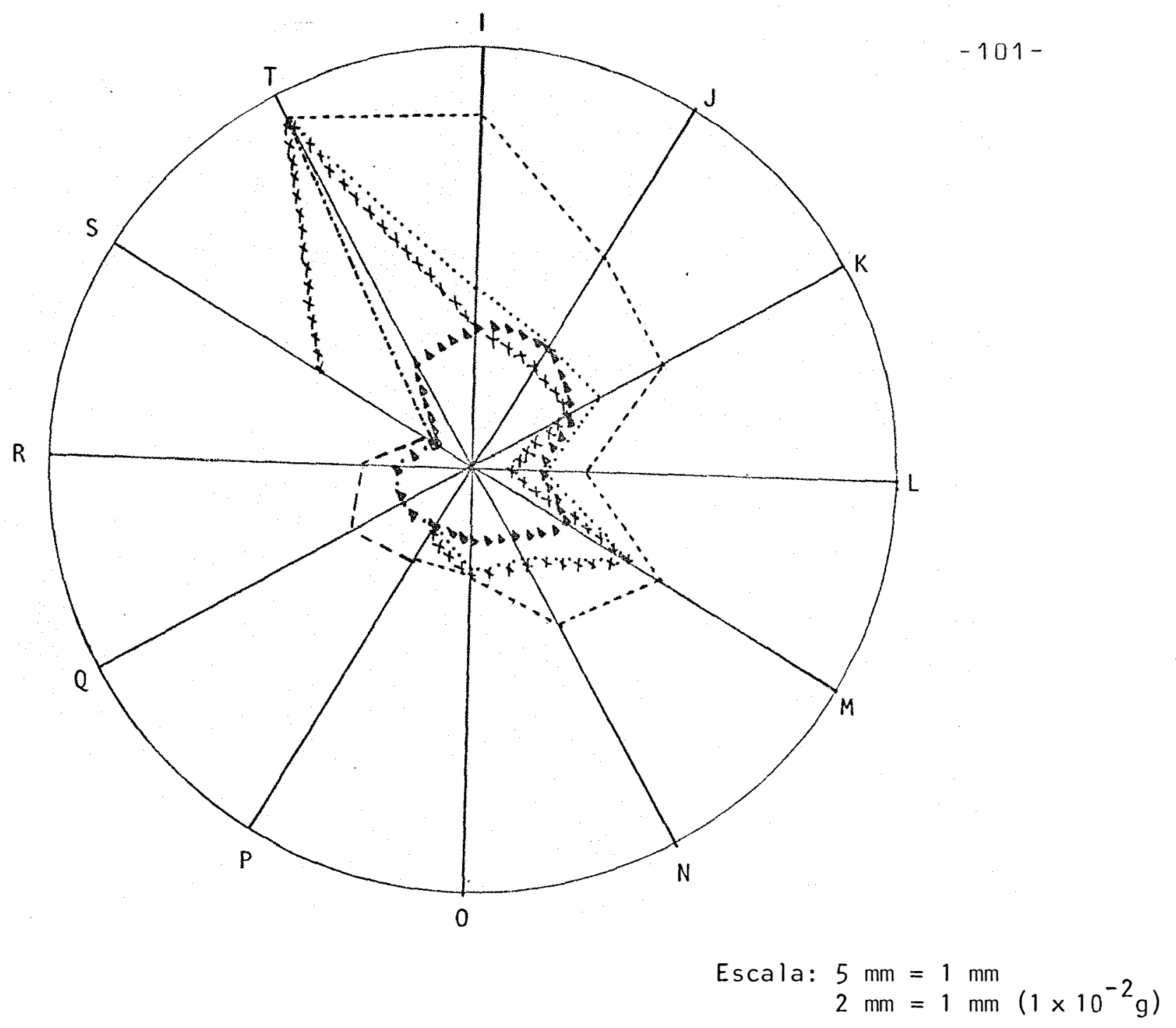

Figura 4 - Distribuição de caracteres florais e do fruto: comprimento do estandarte (1), largura do estandarte (J), comprimento da asa $(k)$, largura da asa $(L)$, comprimento do pedūnculo $(M)$, compr mento do cálice $(N)$, comprimento do artículo superior do fruto $(0)$, largura do artículo superior do fruto $(P)$, comprimento do artículo inferior do fruto (Q), largura do artículo inferior do fruto $(R)$, comprimento do apêndice terminal ( $S$ ) e peso de 100 sementes $(T)$, das espécies S. grandifolia M.B. Ferr. et Sousa Costa (-), S. humilis H.B.K. (x), S. gracilis H.B.K. (.) e S. viscosa.Sw. ( ). Estação Experimental de Anhembi, ESALQ/USP, Piracicaba, SP, 1981. 


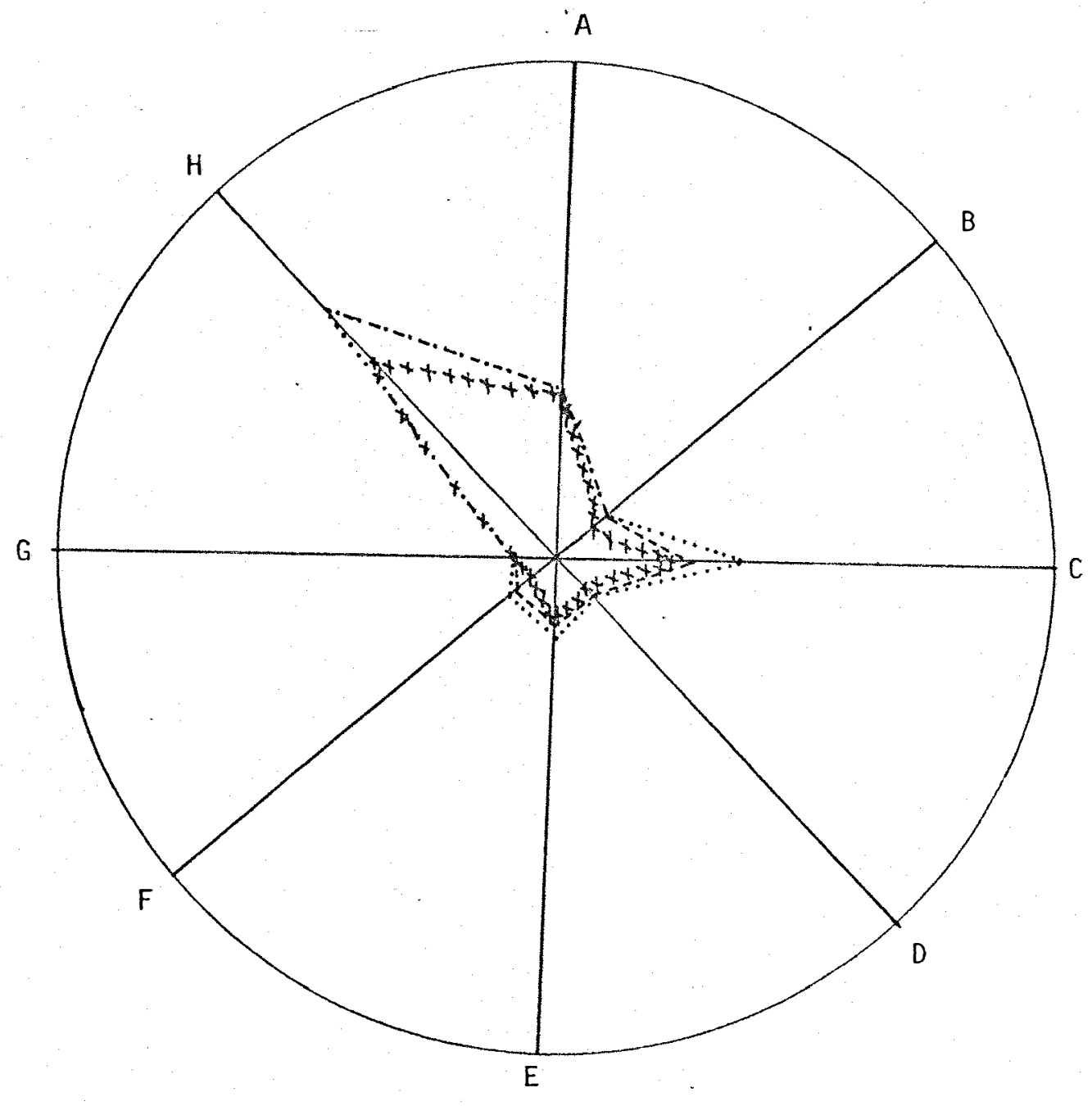

$-102-$

Escala: $1 \mathrm{~mm}$

Figura 5 - Distribuição dos caracteres vegetativos: comprimento do folíolo central (A), largura do folíolo central (B), comprimento do folíolo lateral direito (C), largura do folíolo lateral direito (D), comprimento da estípula (E), largura da estípula (F), comprimento do dente $(G)$ e comprimento do internódio $(H)$, das váriedades vuilgaris M.B. Ferr. et Sousa Costa (-), microcephala M.B. Ferr. et Sousa Costa $(x)$ e canescens M.B. Ferr. et Sousa Costa (.) Estação Experimental de Anhembi, ESALQ/USP, Piraci- caba, SP, 1981. 


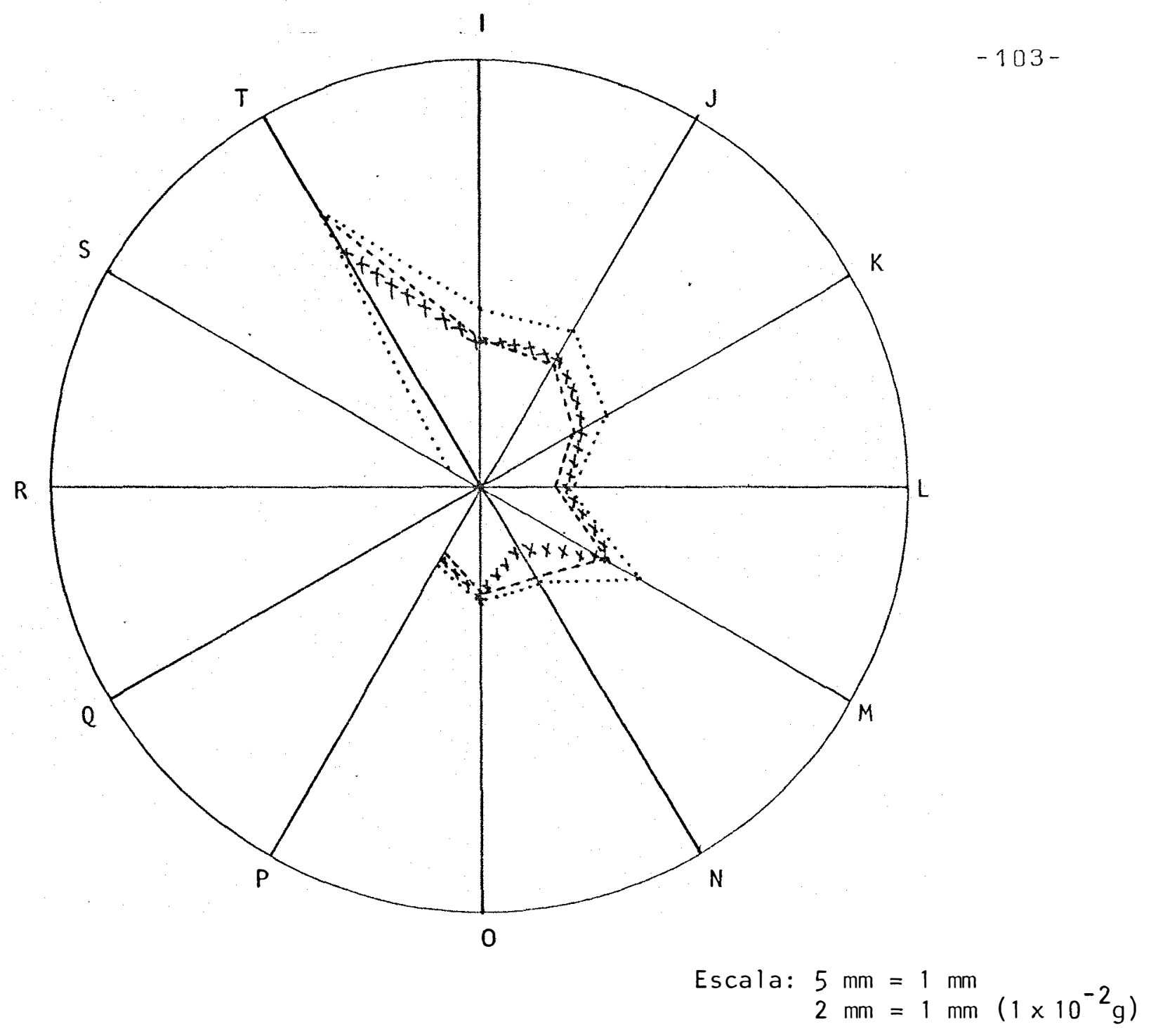

Figura 6 - Distribuição de caracteres florais e do fruto: comprimento do estandarte ( 1 ), largura do estandarte (J), comprimento da asa (K), largura da asa (L), comprimento do pedúnculo (M), compri mento do cálice $(N)$, comprimento do artículo superior do fruto $(0)$, largura do artículo superior do fruto $(P)$, comprimento do artículo inferior do fruto (Q), largura do artículo inferior do fruto $(R)$, comprimento do apēndice terminal (S) e peso de 100 sementes $(T)$, das variedades vulgaris M.B. Ferr. et Sousa Costa (-), microcephala M.B. Ferr. et Sousa Costa (x) e canescens M.B. Ferr. et Sousa Costa (.). Estação Experimental de Anhembi, ESALQ/USP, Piracicaba, SP, 1981. 


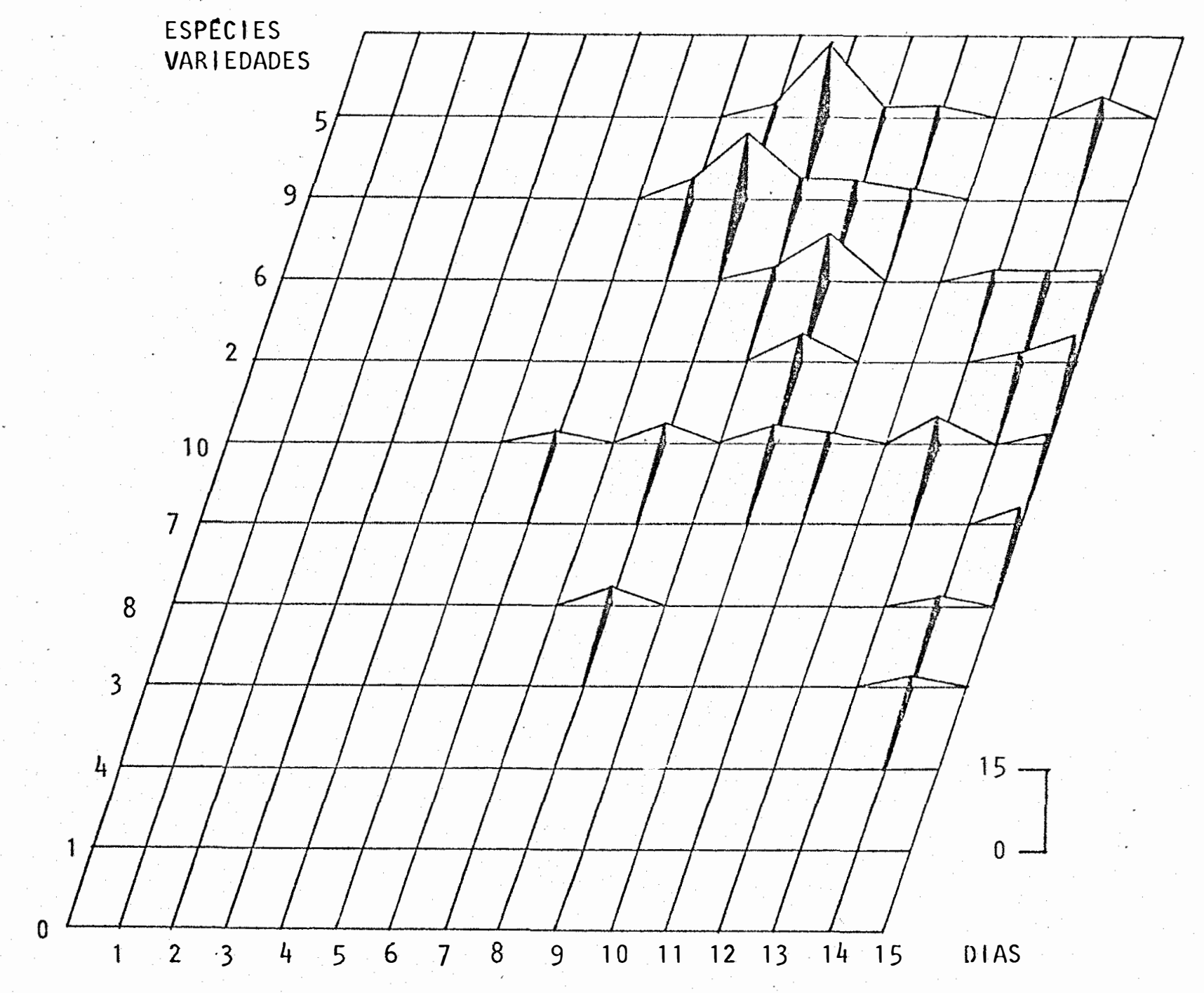

Figura 7 - Representação gräfica da porcentagem de sementes germinadas, por dia, em 7 espécies e 3 variedades de StyZosanthes Sw., em temperatura constante de $15^{\circ} \mathrm{C}$. IGEN-ESALQ/USP. 1980. 


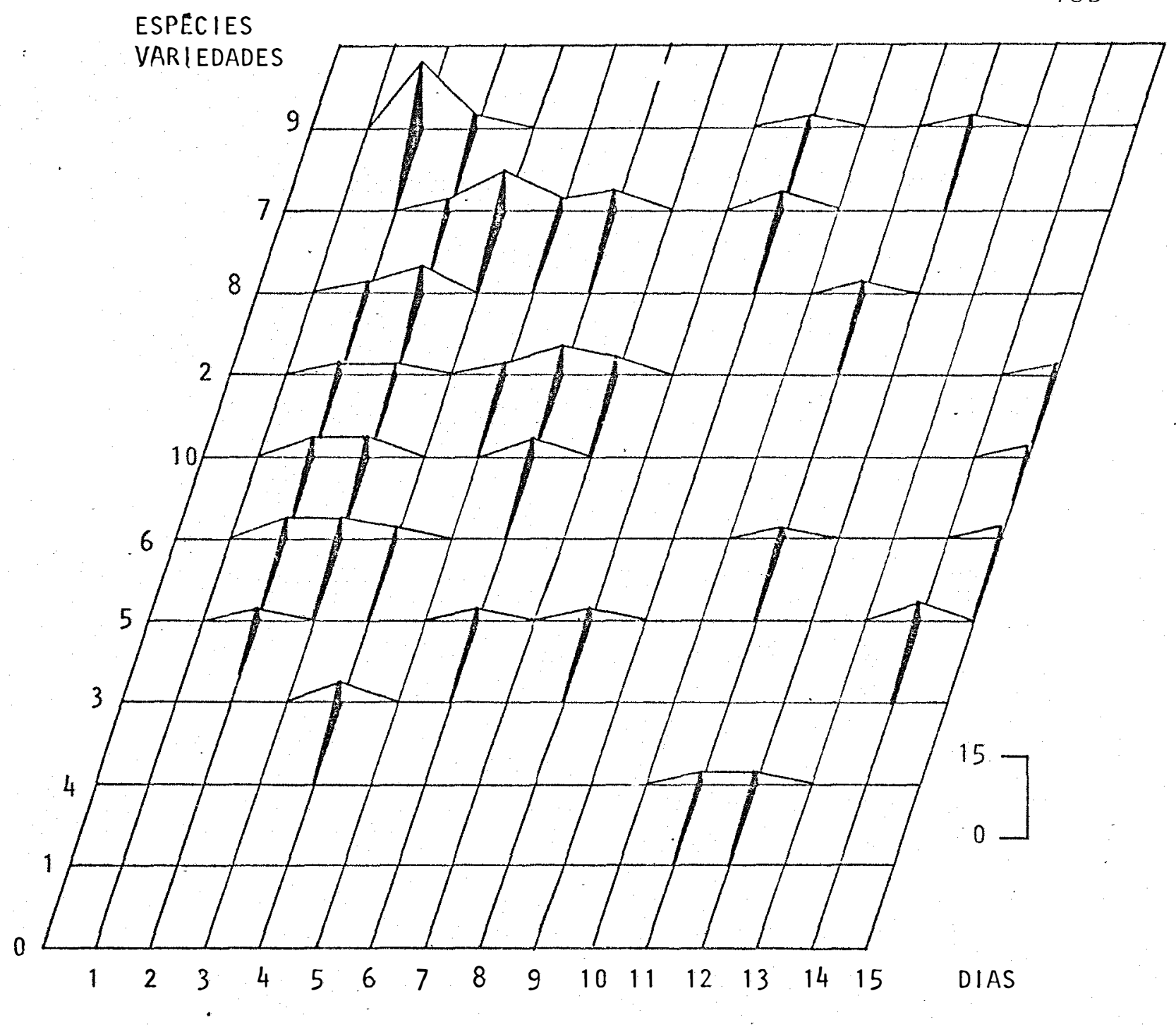

Figura 8 - Representação gráfica da porcentagem de sementes germinadas, por dia, em 7 espécies e 3 variedades de Stylosanthes Sw., em temperatura constante de $25^{\circ} \mathrm{C}$. IGEN-ESALQ/USP. 1980. 


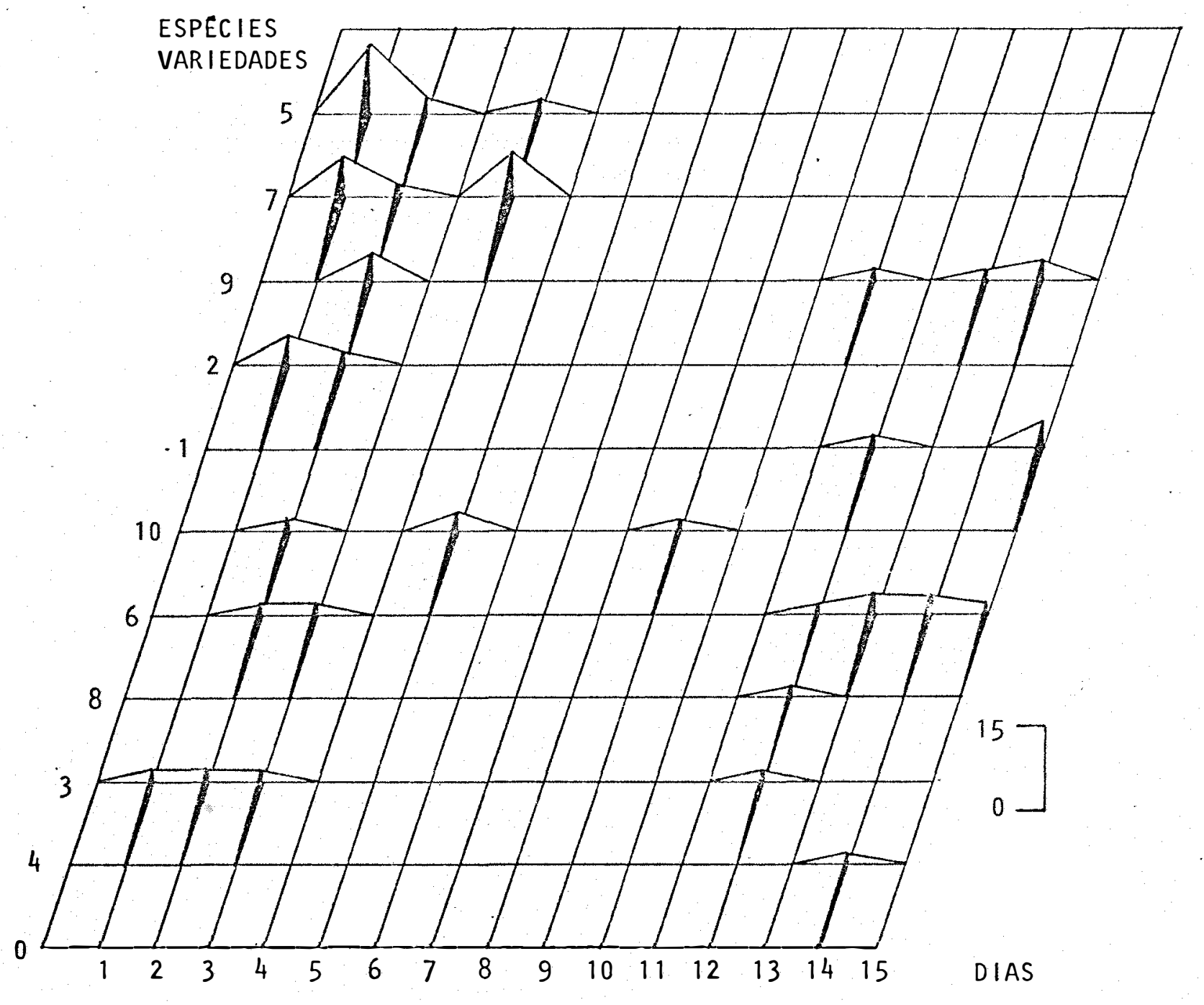

Figura 9 - Representação gräfica da porcentagem de sementes germinadas, por dia, em 7 espécies e 3 variedades de Stylosanthes, em temperatura constante de $35^{\circ} \mathrm{C}$. IGEN-ESALQ/USP. 1980. 